\author{
UNIVERSIDADE DE SÃO PAULO \\ FACULDADE DE EDUCAÇÃO \\ PROGRAMA DE PÓS-GRADUAÇÃO EM EDUCAÇÃO
}

Stella Verzolla Tangerino

EXPERIÊNCIAS AO RÉS DO CHÃO - UMA VISÃO PARA A EDUCAÇÃO POPULAR: estudo de caso sobre o cursinho popular Florestan Fernandes

São Paulo 


\author{
UNIVERSIDADE DE SÃO PAULO \\ FACULDADE DE EDUCAÇÃO \\ PROGRAMA DE PÓS-GRADUAÇÃO EM EDUCAÇÃO
}

Stella Verzolla Tangerino

\title{
EXPERIÊNCIAS AO RÉS DO CHÃO - UMA VISÃO PARA A EDUCAÇÃO POPULAR: estudo de caso sobre o cursinho popular Florestan Fernandes
}

Dissertação de mestrado apresentada à Faculdade de Educação da Universidade de São Paulo como requisito final para obtenção do título de mestre em Educação.

Orientação: Prof. ${ }^{a}$ Dr $^{\mathrm{a}}$. Sonia Maria Portella Kruppa.

São Paulo 
AUTORIZO A REPRODUÇÃO E DIVULGAÇÃO TOTAL OU PARCIAL DESTE TRABALHO, POR QUALQUER MEIO CONVENCIONAL OU ELETRÔNICO, PARA FINS DE ESTUDO E PESQUISA, DESDE QUE CITADA A FONTE.

Catalogação na Publicação

Serviço de Biblioteca e Documentação

Faculdade de Educação da Universidade de São Paulo

$37.06 \quad$ Tangerino, Stella Verzolla

T16e Experiências ao Rés do Chão - uma visão para a Educação Popular: estudo de caso sobre o Cursinho Popular Florestan Fernandes / Stella Verzolla Tangerino; orientação Sonia Maria Portella Kruppa. São Paulo: s.n., 2018

147 p. ils.; ans.; grafs.

Dissertação (Mestrado - Programa de Pós-Graduação em Educação. Área de Concentração: Estado, Sociedade e Educação) - - Faculdade de Educação da Universidade de São Paulo.

1. Educação Popular 2. Movimentos Sociais 3. Curso de Extensão Universitária 4. Política Educacional 5. Emancipação 6.Filosofia I. Kruppa, Sonia Maria Portella, orient.

Elaborada por Natalina de Jesus Delfina da Luz - CRB-8/4018 


\author{
UNIVERSIDADE DE SÃO PAULO \\ FACULDADE DE EDUCAÇÃO \\ PROGRAMA DE PÓS-GRADUAÇÃO EM EDUCAÇÃO
}

Stella Verzolla Tangerino

\title{
EXPERIÊNCIAS AO RÉS DO CHÃO - UMA VISÃO PARA A EDUCAÇÃO POPULAR: estudo de caso sobre o cursinho popular Florestan Fernandes
}

Dissertação de mestrado apresentada à Faculdade de Educação da Universidade de São Paulo como requisito final para obtenção do título de mestre em Educação.

Orientação: Prof. ${ }^{a}$ Dr $^{\mathrm{a}}$. Sonia Maria Portella Kruppa

Data de aprovação: São Paulo, ___ _ / 2018.

Banca examinadora

Prof ${ }^{a}$ Dr $^{\mathrm{a}}$ Sylvia Leser de Mello - Instituto de Psicologia (USP)

Prof ${ }^{\circ}$. Dro Mário Sérgio Cortella - Pontifícia Universidade Católica (PUC)

São Paulo 
Aos meus alunos, que em sua grandeza, chamam-me Professora. Não existe vocativo mais doce aos ouvidos.

À Professora Sônia Kruppa, por permitir meus muitos incêndios filosóficos. Por me abrir o mundo da Educação e fazer dele um lugar no qual eu podia ser como sou e como serei. 


\section{AGRADECIMENTOS}

Aos meus amados pais Laércio e Fátima, que mesmo distantes sempre estão tão perto, pelo zelo com minha formação.

Aos queridos amigos Dr. Maurício Antônio Ribeiro Lopes e Dra. Flávia D’Urso, pela confiança inabalável desde os anos de estágio, cuja generosidade me abriu tantos e tão bons caminhos!

Às Professoras Dra ${ }^{a}$ Lisete Regina Gomes Arelaro e Dra ${ }^{a}$ Cecilia Hannah Mate, da Faculdade de Educação-USP pela leitura cuidadosa na Qualificação e pela inspiração docente.

Ao Professor Dr. Paulo Daniel Elias Farah, do Departamento de Letras Orientais da Universidade de São Paulo (USP), a quem primeiro mostrei o ainda projeto dessa dissertação, pela generosidade em ouvir e alimentar sua realização, com nossa admiração por seu trabalho, sua boa energia, seus bons projetos!

Conta-nos Deleuze em suas Conversações que sempre se trabalha em vários, mesmo quando não vê, mais ainda nesse caso, que é visível:

Ao estimado chefe, Secretário Orlando Lindório de Faria, pela confiança, à chefe de Gabinete do Governo Municipal, Tarcila Peres Santos, pela oportunidade e pelo aprendizado e aos amigos da Secretaria Executiva do Gabinete da Prefeitura de São Paulo: Dedê, Fábio, Ivan, Júnior, Marcela, Rick Stella e Vinicius, pelo exemplo diário dos verdadeiros valores que fazem de nosso Estado uma Democracia de Direito.

Aos Professores do nosso Florestan, pelos seis anos de trajetória, por me ensinarem a cada sábado pelo que e ao lado de quem vale lutar!

Aos colegas do Grupo de Estudos, Ensino e Extensão Multidisciplinar: Estado, Democracia e Educação Pública (GEPEM-EDEP), cujo olhar seguramente melhorou o meu.

Ao Felipe Jaruche Lopes, Thiago Guarato de Carvalho e Vanessa de Lima Benedito, pelo apoio de sempre, amigos queridos "que já viajaram tantas canções comigo e ainda há tantas por viajar...". 
Minha pintura não vem do cavalete. Dificilmente estendo minha tela antes de pintar. Prefiro abri-la numa parede ou no chão. Preciso da resistência de uma superficie dura. No chão estou mais à vontade. Sinto-me mais próximo, mais parte da pintura, pois desta forma eu posso andar em torno dela, trabalhar dos quatro lados e estar literalmente na pintura. (...) Não tenho medo de fazer mudanças, destruindo a imagem, etc., porque a pintura tem uma vida própria. Procuro deixar que ela se manifeste.

Jackson Pollock, My Painting: Possibilities, 1947. 


\section{RESUMO}

TANGERINO, Stella Verzolla. Experiências ao rés do chão - uma visão para a educação popular: estudo de caso sobre o cursinho popular Florestan Fernandes. São Paulo, 2018. Dissertação (Mestrado em Educação) - Faculdade de Educação, Universidade de São Paulo.

Nosso estudo oferece a problematização político-pedagógica da experiência docente em um Cursinho Popular Pré Vestibular da Capital paulista (Cursinho Popular Florestan Fernandes), pesquisa que evoca em seus capítulos alguns tensionsamentos: a cultura da elitização do acesso ao ensino superior, os obstáculos ao ingresso no ensino superior pelos alunos de escola pública e a até mesmo como a urbanização de São Paulo tem reproduzido em larga medida, as desigualdades educacionais. Animados da convicção de que a resposta aos desafios que nos colocam as complexas questões da experiência educacional contemporânea somente pode ser pensada e enfrentada criativamente, em espaços de realização histórica não formais, os cursinhos populares acenam como instrumentos alternativos e originais não apenas de inclusão ou de preparo para o vestibular, mas, sobretudo, de um trabalho de empoderamento do estudante. As entrevistas e relatos das práticas que trouxemos afirmam a validade da estrutura do Cursinho como instância de transformação de um interdito inicial em experiências emancipadoras, tarefa que se realiza em conjunto e como ensina-nos Paulo Freire, de modo solidário. À medida em que se desenvolve a temática da construção de espaços que asseguram a oportunidade de acesso dos grupos discriminados, ampliando sua participação em diferentes setores da vida econômica, política, institucional, cultural e social, as reflexões finais do trabalho voltam-se a um olhar sobre o ensino da Filosofia no Cursinho, à maneira socrática: como gesto político e como potência do pensar, reflexo do trabalho de seis anos de docência da autora com essa disciplina.

Palavras-chave: movimentos sociais; educação popular; cursinho popular; política educacional; emancipação; filosofia. 


\begin{abstract}
TANGERINO, Stella Verzolla. Experiences on the floor - a vision for popular education: case study on the popular course Florestan Fernandes. São Paulo, 2018. Dissertation (Master in Education) - Education College, University of São Paulo.

This study presents an overview about the teaching experience in a political and a pedagogy approach on popular and alternative Brazilian courses to access higher education in São Paulo, capital city (specifically, Florestan Fernandes). Mainly this study demonstrate several tensions on the elitism cultural in access Higher Education, the barriers that students from public education face to access Higher Education and even how urbanization spaces in São Paulo city has contribute to raising educational inequalities. The many and complex challenges faced in teaching experience encouraged us to find it those answers out of the box - creatively - in a historical space of achievement outside the power of State and governments. The popular preparatory courses to acess higher education arise not merely as alternative feature to inclusion or to support students to access Higher Education, but, above all, as student empowerment work. To support our results in this study we show interviews and practice reports that confirmed the framework of popular preparatory as a space of transformation in an initial interdict in emancipatory experiences, a task that is carried out jointly - and in a solidary way - as Paulo Freire already stated. Once the thematic about building spaces as an opportunity to ensure access to vulnerable groups develops - raising that participation in different areas of life (economic, politic, institutional, cultural and social aspects) the conclusions of this study turn to reflections about teaching of Philosophy in preparatory, as Socrates said: to teach as a political gesture and as a power of thought.
\end{abstract}

Keywords: social movements; popular education; alternative educational policies; emancipation; philosophy. 


\section{LISTA DE GRÁFICOS}

Gráfico 1 - Distribuição equipamentos urbanos por área no município de São Paulo...........................29

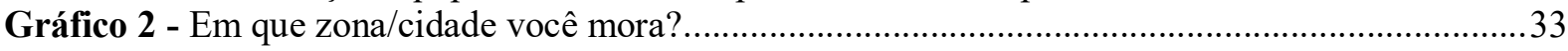

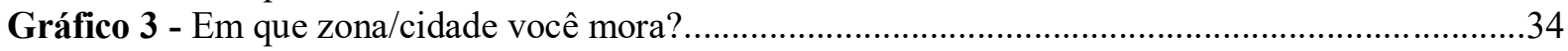

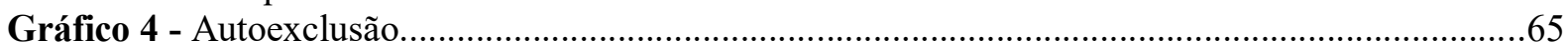

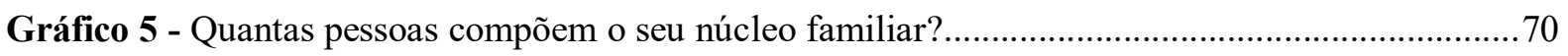

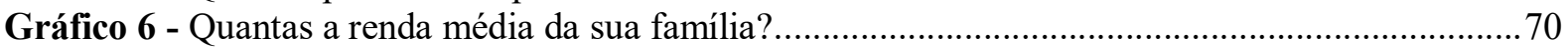

Gráfico 7 - Quantas pessoas contribuem para a renda familiar? ........................................................ 71

Gráfico 8 - Quantas conduções você utilizará para chegar ao cursinho? ..............................................71

Gráfico 9 - Quantas pessoas compõem o seu núcleo familiar?.........................................................72

Gráfico 10 - Quantas a renda média da sua família?..........................................................................72

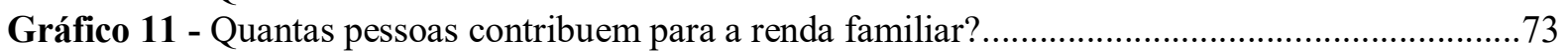

Gráfico 12 - Quantas conduções você utilizará para chegar ao cursinho? .........................................73

Gráfico 13 - Quantas pessoas compõem o seu núcleo familiar?.........................................................74

Gráfico 14 - Quantas a renda média da sua família?.........................................................................74

Gráfico 15 - Quantas pessoas contribuem para a renda familiar?.................................................... 75

Gráfico 16 - Quantas conduções você utilizará para chegar ao cursinho? .............................................75

Gráfico 17 - Prioridade do ensino médio, por série (\%).....................................................................79 


\section{SUMÁRIO}

INTRODUÇÃO

CAPÍTULO 1: Experiências ao rés do chão ……………………………………………...... 19

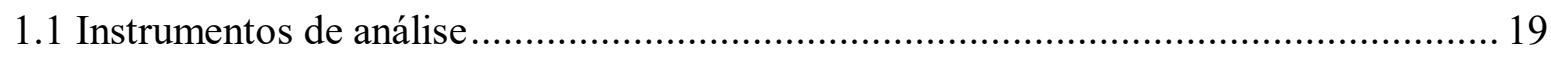

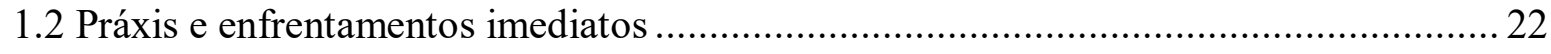

1.3 "Efeitos de lugar": o Cursinho no espaço urbano …………………………………..... 26

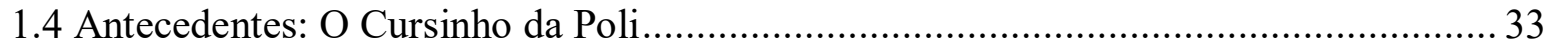

1.5 Antecedentes: a Rede Emancipa - Movimento Social de Cursinhos Populares ............ 35

CAPÍTULO 2: O Cursinho Popular Florestan Fernandes (CPFF) ...................................... 38

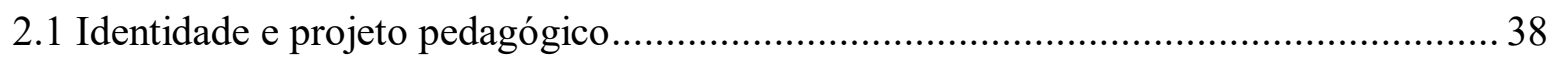

2.1.1 Elementos estruturantes: círculos, oficinas e aulas em movimento ......................... 40

2.2 Carta de princípios e I Congresso de Educação Popular Florestan Fernandes ............... 45

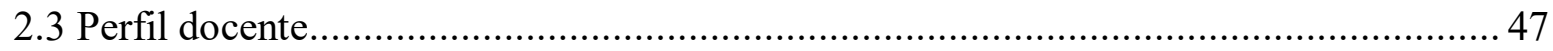

$2.4 \mathrm{O}$ estudante: vulnerabilidades e descoberta de direitos ...............................................59

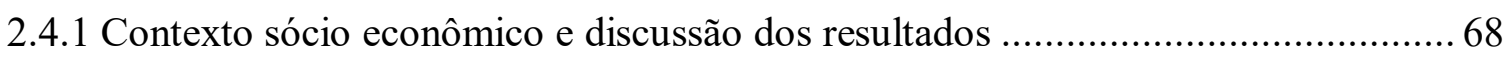

CAPÍTULO 3: Ensinar filosofia no cursinho popular - Convergência política e

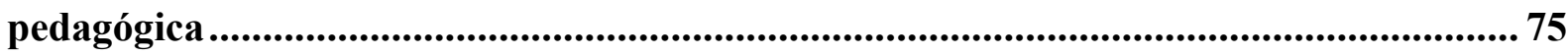

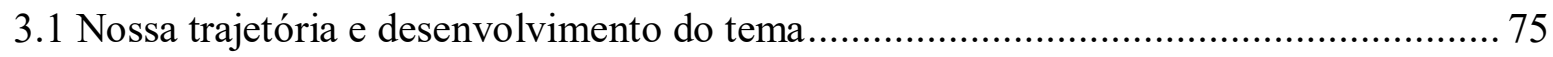

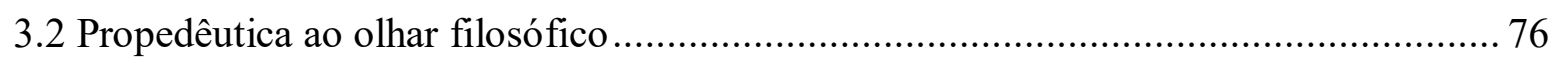

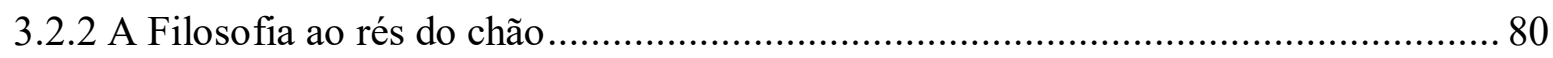

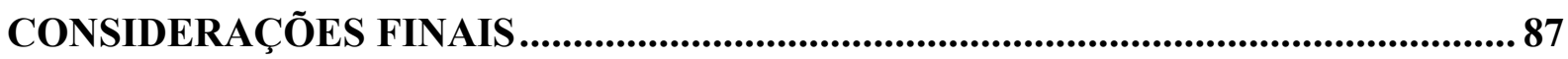

REFERÊNCIAS BIBLIOGRÁFICAS ....................................................................... 90

ANEXO 1 - Apostila Cursinho do Grêmio - Filosofia (USP) .............................................. 101

ANEXO 2 - Carta aos professores e à direção do Cursinho da Poli (11/2004)...................... 103

ANEXO 3 - Ofício para requisição das salas de aulas - Faculdade de História (USP) ........ 106

ANEXO 4 - Carta do Cursinho Florestan Fernandes em ruptura à Rede Emancipa (2016) . 107

ANEXO 5 - Grade horária - Cursinho Florestan Fernandes ............................................... 110

ANEXO 6 - Manual do aluno - Rede Emancipa …………………………………….... 112

ANEXO 7 - Manual do professor - Rede Emancipa …………....................................... 120

ANEXO 8 - Cronograma unificado dos conteúdos por disciplina ……………………...... 130

ANEXO 9 - Oficinas e atividades desevolvidas no Cursinho Popular Florestan Fernandes. 143 


\section{INTRODUÇÃO}

[...] O grito que consegue ressoar precisamente porque o desarraigamento da modernidade fez ruir as precisões das formas não é apenas grito de dor de uma "vida ofendida" mas é também expressão do espiritual que abre caminho através das ruinas das formas.

Gianni Vattimo ${ }^{1}$

Nosso propósito é apresentar as experiências pedagógicas de um Cursinho Popular em uma reflexão que ressignifica a urgência das necessidades da Educação e da militância contemporâneas, traduzidas em uma semântica de transformação social de uma dinâmica que se nutre justamente da denúncia de práticas educacionais agonizantes e pouco comprometidas com a democracia e da emergência do novo que o acompanha.

A Educação vivenciada nos movimentos sociais "não se paga, dá-se de graça, transborda",2, mas é, como toda experiência social, sob vários aspectos paradoxal ${ }^{3}$ : quer anunciar as insuficiências de um sistema obsoleto, quer propor outros significados, mas precisa negociar com ele, quase aderir, "estar dentro e fora do Estado". Precisa articular de forma conjugada a invisibilidade, a exclusão, a subalternidade com o ativismo, a dialética, o otimismo. Felizmente, já nos dizia Heráclito que tudo de belo se faz justamente da luta dos contrários. ${ }^{5}$

O estudo possibilitará a compreensão do universo simbólico de um coletivo autônomo, informal, voluntário e heterogêneo dedicado à realização de atividades de caráter preparatório para os exames de ingresso no ensino superior, mas, sobretudo, como se verificou, promotor de experiências diversas além das tradicionais providas no contexto da escola regular:

\footnotetext{
${ }^{1}$ VATTIMO, G. O fim da modernidade: niilismo e hermenêutica na cultura pós-moderna. $2^{\mathrm{a}}$ ed. São Paulo: Martins Fontes, 2017.

2 TRINDADE, R. Zaratustra e a dança. 2015. Disponível em $<$ https://razaoinadequada.com/2015/05/27/zaratustra-e-a-danca/>. Acesso em 23 jan. 2018.

3 "Embora a política dos CPVCs como solução emergencial e compensatória pareça a muitos criticável, é provável projetar uma sobrevida dos CPVCs por mais uma década, até que se efetive no Brasil uma reforma de qualidade da educação básica, que articule tanto as esferas públicas estaduais, municipais e federal, quanto as da sociedade civil, caracterizando assim os CPVCs como uma política eventualmente dispensável no futuro". In: CARVALHO, J. C. B.; ALVIM FILHO, H.; COSTA, R. P. (Orgs.). Cursos Pré-vestibulares Comunitários: espaços de mediação pedagógica. Rio de Janeiro: PUC-Rio, 2005, p. 13.

${ }^{4}$ FREIRE, P. Política e educação. São Paulo: Cortez, 1993, p. 34.

${ }^{5}$ LEBRUN, G. A filosofia e sua história. São Paulo: Cosac Naify, 2006.
} 
emancipação ${ }^{6}$, conscientização, socialização e abertura do espaço urbano a jovens em situação de vulnerabilidade econômica da Capital paulista.

O Cursinho Popular tem a singularidade de colocar-se como uma criação corajosamente original de confronto às obscenidades do capitalismo da abundância ${ }^{7}$, na expressão do filósofo esloveno Zizek e enlaçar essa carência, remetendo a um duplo movimento: promover "a cidadania, emancipação humana, uma cultura democrática e solidária" e se apresentar "como construção coletiva de resistência, de enfrentamento às imposições das políticas educativas oficiais e como negação da negação ao direito à educação". ${ }^{8}$

Revela-se, portanto, como uma Educação de trincheira, de anseio de ir "além do Capital"". Uma espécie de "terceira margem do rio"10: "o exercício de uma leitura do mundo, que exige a compreensão critica da realidade, supõe, por um lado, sua denúncia ${ }^{11} \mathrm{e}$, por outro, o anúncio do que ainda não existe". ${ }^{12}$

Uma nova visão da educação, que, como diz nos Gadotti, "não é apenas uma pedagogia da resistência, mas, sobretudo, uma pedagogia da esperança e da possibilidade"13 e a Educação popular é, na expressão de Homi Bhabha justamente esse "entrelugar" ${ }^{14}$, um espaço fronteiriço, de alteridade entre experiências contra hegemônicas, de preparação para provas que são

\footnotetext{
${ }^{6}$ Rúrion Melo citando Laclau adverte-nos: não se trata de falar mais na emancipação, mas sim em emancipações. Laclau identifica na variedade de tais "emancipações" uma característica constante, a saber, a "rebelião de vários particularismos - étnicos, raciais, nacionais e sexuais - contra as ideologias totalizadoras que dominaram o horizonte da política nas décadas precedentes". In: MELO, R. Emancipação hoje e os desafios da democracia. Cadernos de Ética e Filosofia Política, São Paulo, v. 22, 2013, p. 7.

${ }^{7}$ ŽIŽEK, S. Arriscar o impossivel - conversas com Zizek. Trad. Vera Ribeiro. São Paulo: Martins Fontes, 2006. Coleção Dialética, p. 22.

${ }^{8}$ BATISTA, M. S. X. Educação popular em movimentos sociais: construção coletiva de concepções e práticas educativas emancipatórias. In: $28^{\mathrm{a}}$ REUNIÃO NACIONAL DA ANPED, 2005, Caxambu. Anais...Caxambu: ANPED, 2005, p. 7.

${ }^{9}$ MÉSZÁROS, I. A educação para além do capital. São Paulo: Boitempo, 2008.

${ }^{10}$ Aludimos ao conto "A Terceira margem do rio", da obra Primeiras estórias, de Guimarães Rosa. A propósito, Aline Lemos da Cunha (2008) afirma: "as margens possibilitam saídas criativas para necessidades urgentes". In: CUNHA, A. L. Mulheres negras e suas práticas profissionais: constituição de espaços educativos e resistência da não-formalidade. In: VII SEMINÁRIO DE PESQUISAS EM EDUCAÇÃO DA REGIÃO SUL, 2008, Itajaí. Anais... Itajaí: ANPED, 2008, v. 1, p. 12.

${ }^{11}$ Leon Crochík lembra-nos que não é possível pensar em um projeto de democratização que prescinda da discussão anterior e necessária sobre o tipo de educação que será oferecida. In: CROCHÍK, J. L. Os desafios atuais do estudo da psicologia na modernidade. Psicologia USP, São Paulo, v. 9, n. 2, 1998.

${ }^{12}$ FREIRE, P. Pedagogia da indignação: cartas pedagógicas e outros escritos. São Paulo: Editora Unesp, 2000.

${ }^{13}$ GADOTTI, M. Boniteza de um sonho: ensinar-e-aprender com sentido. Novo Hamburgo: Feevale, 2003 , p. 47.

${ }^{14}$ BHABHA, H. K. O local da cultura. Belo Horizonte: Ed. UFMG, 1998.
} 
instituídas e reguladas pelo sistema excludente que se quer combater, de mediação do encontro entre o que existe para poucos e algo que "começa a se fazer presente...."

Sobre o entrelugar, destacamos:

O trabalho fronteiriço da cultura exige um encontro com "o novo" que não seja parte do continuum de passado e presente. Ele cria uma ideia do novo como ato insurgente de tradução cultural. Essa arte não apenas retoma o passado como causa social ou precedente estético; ela renova o passado, refigurando-o como um "entre-lugar" contingente, que inova e interrompe a atuação do presente. $\mathrm{O}$ "passado-presente" torna-se parte da necessidade, e não da nostalgia, de viver. ${ }^{16}$

A crença de que a política estatal proverá, à revelia do horizonte econômico vigente que se compraz na competição brutal e na mais-valia, iguais condições de acesso à Educação superior é ingênua e anacrônica, haja vista as muitas relações erigidas no contexto da democracia liberal mostrarem-se ainda atravessadas por antagonismos e contradições.

De acordo com Sacristán,

\begin{abstract}
A igualdade na educação tem múltiplas significações, visto tratar-se de uma ambição que, se por um lado combate as desigualdades de oportunidades para atingir determinados fins, deverá ao mesmo tempo ser respeitadora para com a liberdade e alguns direitos a sermos diferentes. Por esse motivo, a igualdade e a diferença (dois direitos que não devem ser entendidos como opostos, tal como não se deve considerar que um deles é superior ao outro) terão de ser estabelecidos como propósitos interdependentes, de maneira a que as exigências surgidas a partir de um deles sejam compatíveis com as que o outro exige. A diferenciação educativa só é admissível se não obstruir o caminho da igualdade; a aspiração à igualdade só será sustentável quando não se opuser ao respeito pelas diferenças tidas como legítimas. Existe, portanto, e além do mais, uma igualização não desejável e uma diferenciação desigualadora que segrega, algo que é totalmente inadmissível. ${ }^{17}$
\end{abstract}

O capitalismo da modernidade ${ }^{18}$ é obcecado pela redução dos "direitos sociais em serviços sociais prestados pelo Estado e pelo Mercado"19 e parece reeditar, "num gesto de

\footnotetext{
${ }^{15}$ BHABHA, Op. Cit., 1998, p. 24.

${ }^{16}$ BHABHA, Op. Cit., 1998, p. 27.

${ }^{17}$ SACRISTÁN, J. G. Educar e conviver na cultura global. Porto: Edições Asa, 2003, p. 324.

${ }^{18}$ Safatle posfaciando Zizek afirma: "A história das formas capitalistas é sempre, necessariamente, uma história relativa. O capitalismo só se submete a transformações sistêmicas quando é obrigado(...). Para captar o processo da perspectiva de seu elemento ativo, precisamos adotar o ponto de vista do outro lado (...) o proletariado inventa, efetivamente, as formas sociais e produtivas que o capital será obrigado a usar no futuro". In: SAFATLE, V. A política do Real de Slavoj Zizek. In: ZIZEK, S. Bem-vindos ao deserto do real. São Paulo: Boitempo, 2012, p. 185.

${ }^{19}$ GADOTTI, M. Estado e educação popular - desafios de uma política nacional. 2016. Disponível em: $<$ http://www.participa.br/articles/public/0006/3700/Estado_e_Educa\%C3\%A7\%C3\%A3o_Popular Gadotti.pdf>. Acesso em 21 jul. 2016.
} 
despedida apressada" 20 a inutilidade de esperarmos alguma forma de negação à lógica de mercadorias, à lógica que "tem na exclusão parte importante do funcionamento do sistema". ${ }^{21}$ Notadamente, "o setor do ensino superior foi atravessado de maneira brutal por essas dinâmicas"22; nas palavras da filósofa Marilena Chauí, a

[...] localização da educação no setor de serviços não exclusivos do Estado significou: a) que a educação deixou de ser concebida como um direito e passou a ser considerada um serviço; b) que a educação deixou de ser considerada um serviço público e passou a ser considerada um serviço que pode ser privado ou privatizado. ${ }^{23}$

Pensar a educação sem considerar seu acesso igualitário, paradigma fundante de nosso Estado de Direito, seria atestar a primitiva condição de que não ultrapassamos ainda a fronteira de uma terça parte das disposições preambulares de nossa Constituição. É então, cremos, somente por meio de uma nova leitura de intervenção no tecido social, aliada a uma ressignificação do Direito e da Educação que poderemos enfrentar uma estrutura que forma e reproduz atores em disputa nas estruturas de classe $^{24}$, na expressão aguda do filósofo Poulantzas: estruturas que "perpetuam a organização das classes economicamente dominantes e a desorganização das classes dominadas". ${ }^{25}$

Por certo, supõe-se que o Direto ao acesso à Educação, firmado e reconhecido nos instrumentos normativos e nos fóruns internacionais da atualidade, constitui-se um dos alicerces de qualquer Democracia. Todavia, vemos que escasseiam as ações e abundam os instrumentos normativos ${ }^{26}[\ldots]$ "o direito abunda, mas, pelo visto, não para fins de reforma

${ }^{20}$ HABERMAS, J. Arquitetura moderna e pós-moderna. Novos Estudos - CEBRAP, São Paulo, v. 8, n. 18, set. 1987 , p. 115.

${ }^{21}$ CASTEL, R. As metamorfoses da questão social: uma crônica do salário. Rio de Janeiro: Vozes, 1998, p. 143.

${ }^{22}$ NASCIMENTO, A. Do direito à universidade à universalização de direitos: o movimento dos cursos pré-vestibulares populares e as políticas de ação afirmativa. Rio de Janeiro: Litteris Editora, 2012, p. 2. ${ }^{23}$ CHAUÍ, M. A universidade pública sob nova perspectiva. Rev. Bras. Educ., Rio de Janeiro, n. 24, 2003, p. 6. Disponível em: <http://www.scielo.br/scielo.php?script=sci_arttext\&pid=S1413$24782003000300002 \& \operatorname{lng}=$ en\&nrm=iso $>$. Acesso em 13 jan. 2017.

24 “A educação não é o único elemento da superação das desigualdades sociais e raciais, mas é um direito humano e constitucional que contribui diretamente no enfrentamento dos demais fatores de exclusão e na constituição de espaços de diálogo, reflexão e interação cultural", cf. GONÇALVES, E. Educação de jovens e adultos e relações étnico-raciais. In: CATELLI JR., R. (org.). Formação e pratica na educação de jovens a adultos. São Paulo: Ação Educativa, 2017, p. 13.

${ }^{25}$ POULANTZAS, N. O Estado, o poder, o socialismo. São Paulo: Paz e Terra, 2000, p. 46.

${ }^{26}$ A esse respeito, Bobbio diz-nos: "Naturalmente, é necessário não esquecer que um ethos representa o mundo do dever ser. O mundo real nos oferece, infelizmente, um espetáculo muito diferente. À visionária consciência a respeito da centralidade de uma política tendente a uma formulação, assim como a uma proteção, cada vez melhor dos direitos do homem, corresponde a sua sistemática violação em quase todos os países do mundo, nas relações entre um país e outro, entre uma raça e outra, entre 
social, enquanto a revolução pura e simplesmente desapareceu, é legítimo perguntar se não devemos procurar novas concepções para que a transformação social faça sentido". ${ }^{27}$

Bem assim, a educação popular para os nossos tempos vem inaugurar uma alternativa a essa leitura acabada e excludente, vez que "não se trata apenas de um pensamento educacional, mas também de um movimento de educadores". ${ }^{28}$ Trazendo a possibilidade de

[...] desconstruir a anterior neutralidade da Pedagogia e do currículo e o presumido papel do educador como um iluminado. De relacionar a educação a questões de poder, saber e identidade. De compreender os processos de controle e regulação pelos quais as pessoas tornam-se aquilo que são. De retirar todo o papel ingênuo, universalista e eterno da Pedagogia, dando-lhe o que ela sempre mereceu: a dimensão de ser, irredutivelmente, um campo politico, socialmente interessado, território de culturas em luta, e muitíssimo forte para construir uma ou outra realidade, uma ou outra sociedade, um ou outro valor, um ou outro tipo de sujeito. É o tempo da revolução em educação. $^{29}$

Conforme anota Telles:

Direitos que recriam desigualdades, pela sua vinculação profissional, são também direitos que não se universalizam, sobrepondo às diferenças sociais uma outra clivagem que transforma em "não-cidadãos" os que escapam às regras do contrato. Esses são os "não-iguais", os que não estão credenciados à existência cívica justamente porque privados de qualificação para o trabalho. São os pobres, figura clássica da destituição. Para eles, foi reservado o espaço da assistência social, cujo objetivo não é elevar as condições de vida, mas minorar as desgraças e ajudara sobreviver na miséria. ${ }^{30}$

poderosos e fracos, entre ricos e pobres, entre maiorias e minorias, entre violentos e conformados. $\mathrm{O}$ ethos dos direitos do homem resplandece nas declarações solenes que permanecem quase sempre, e quase em toda parte, letra morta". In: BOBBIO, N. A era dos direitos. Trad. Carlos Nelson Coutinho. Rio de Janeiro: Elsevier, 2004, p. 230.

${ }^{27}$ SANTOS, B. S. Poderá o direito ser emancipatório? Revista Crítica de Ciências Sociais, Coimbra, n. 65, 2003.

${ }^{28}$ MOTA NETO, J. C. A educação popular e o desenvolvimento de propostas pedagógicas na educação de jovens e adultos. In: CATELLI JR., Op. Cit., 2017, p. 149.

${ }^{29}$ CORAZZA, S. M. Nos tempos da educação: cenas de uma vida de professora. Revista da ABEM, Porto Alegre, V. 12, 7-10 mar. 2005, p. 09.

${ }^{30}$ TELLES, V. S. Pobreza e cidadania. São Paulo: Editora 34, p. 26. 
Assim, o Direito ${ }^{31}$ ou é reconhecedor de padrões atuais, socialmente adequados, relevantes e observados, ou será apenas lei. O direito é legítimo, a lei nem sempre ${ }^{32}$. E ademais, lembra-nos Maria da Glória Gohn,

A cidadania não se constrói por decretos ou intervenções externas, programas ou agentes pré-configurados. Ela se constrói como um processo interno, no interior da prática social em curso, como fruto do acúmulo de experiências engendradas. A cidadania coletiva é construidora de novos sujeitos históricos: as massas urbanas espoliadas e as camadas médias expropriadas. A cidadania coletiva se constrói no cotidiano através do processo de identidade política cultural que as lutas cotidianas geram. ${ }^{33}$

É a partir deste movimento que nos parece ser possível compreender a educação que se pratica no âmbito do Cursinho Popular. Uma “(...) produção alternativa de subjetividade, que não apenas resista ao poder, mas busque autonomia com relação a ele" ${ }^{34}$, um movimento que expresse, no dizer de Nascimento, a superação do "Direito aos Direitos. ${ }^{35}$

Experiências ao rés do chão traz a discussão de alguns desses papéis atribuídos a educação popular na atualidade, lançando o olhar em um primeiro momento sobre o histórico do Cursinho e sobre a cidade no qual ele se insere, como reveladora do humano ou do desumano que ele próprio tentará problematizar.

A dialética das contradições que permeiam o tema, sua estrutura, atores, as narrativas dos alentos e desalentos deste desafio educacional que se inscreve em um movimento crescente de transformação e redescoberta são analisados no segundo capítulo. As impressões sobre a construção da Filosofia no âmbito do Cursinho Popular estudado arejam o capítulo final de

\footnotetext{
${ }^{31}$ Interessante análise a de Naves, acerca do Direito: “A relação de exploração capitalista, como lembra Pachukanis, é mediada por uma específica operação jurídica, a forma de um contrato, ao contrário da sociedade feudal, em que completa sujeição do servo ao senhor feudal, exercida pela coerção direta, não exigia "uma formulação jurídica particular". In: NAVES, M. B. Marxismo e direito: um estudo sobre Pachukanis. São Paulo: Boitempo, 2000, p. 69.

32 "As Constituições modernas são, nesse sentido, exemplos de mitos modernos, porque instalam no seio da coletividade a convicção de que se vive sob a égide do Estado de Direito apenas porque o documento formal expressa a existência de um Estado de Direito. A Constituição formal, assim, desnuda-se como instrumento de dominação ideológica. É mito que acalentamos, dotado de valor referencial exemplar, na medida em que contribui eficazmente para a preservação da ordem que não se pretendia instaurar, mas, simplesmente, manter." In: OLNEY, Q. A.; KÜMPEL, V. F. Manual de antropologia jurídica. São Paulo: Saraiva, 2011, p. 123.

${ }^{33}$ GOHN, M. G. Teorias dos movimentos sociais: paradigmas clássicos e contemporâneos. São Paulo: Loyola, 1997, p. 16-17.

${ }^{34}$ NEGRI, A.; HARDT, M. Império. Rio de Janeiro: Record, 2000, p. 289.

${ }^{35}$ ZIZEK, Op. Cit., 2006, p. 78.
} 
nossa investigação em seus diversos matizes: o protagonismo do aluno, o "partejar" das idéias, “a provocação e o convite". ${ }^{36}$

Por isso, também se pode dizer que o presente trabalho que se abre com a denúncia de um cenário desesperado, se pretende, encerrar com uma convocação à esperança Freireana. Na leitura do professor Milton Santos: "Quando consideramos a história possível e não apenas a história existente, passamos a acreditar que outro mundo é viável". ${ }^{37}$

${ }^{36}$ CERLETTI, A. O ensino de filosofia como problema filosófico. Tradução Ingrid Müller Xavier. Belo Horizonte: Autêntica Editora, 2009, p. 39.

${ }^{37}$ SANTOS, M. "O professor como intelectual na sociedade contemporânea". In: $I X$ ENCONTRO NACIONAL DE DIDÁTICA E PRÁTICA DE ENSINO, vol. III, São Paulo. Anais... São Paulo: 1999, p. 14. 


\section{CAPÍTULO 1: Experiências ao rés do chão}

As coisas começam no chão.

Davi Machado sobre a poética de Manoel de Barros ${ }^{38}$

\subsection{Instrumentos de análise}

O fotógrafo Sebastião Salgado diz-nos que a única maneira de contar uma história é voltar ao mesmo lugar repetidas vezes ${ }^{39}$. Há detalhes e impressões que não são apreensíveis de imediato em que pese nosso empenho estético na atitude do ver, precisamos do frescor etnográfico de algumas "pontes comunicativas" ${ }^{40}$, que só a reconstituição nos permite alcançar. ${ }^{41}$ Esse é um estudo feito do retorno ao mesmo lugar por todos os sábados durante seis anos.

Nossa leitura do rés do chão vem da observação e da aposta em experiências de Educação que nascem não no solo exausto "dos ministérios e secretarias, dos gabinetes" 42 , mas em um espaço simples "que interage com os outros, com o ambiente, com a história e as estórias" 43 , "que ganha vida no decorrer do diálogo"44, que tenta contornar a educação "instituída e que quer instituir-se" 45 para construir outras possibilidades.

Chegamos a nosso objeto de pesquisa em março de 2013, pelo intermédio de um colega do curso de bacharelado em Filosofia na Universidade de São Paulo, que já desenvolvia trabalho voluntário de professor na Rede Emancipa e nos apresentou a unidade Florestan

\footnotetext{
38 MACHADO, D. Q. Manoel de Barros ou O Paraíso é no Chão. 2017. Disponível em $<$ https://homoliteratus.com/manoel-de-barros-ou-o-paraiso-e-no-chao >. Acesso 17 jun. 2018.

${ }^{39}$ SALGADO, S. Da minha terra à terra - pela primeira vez, o maior fotojornalista do mundo conta sua história. Rio de Janeiro: Paralela, 2014, p. 29.

${ }^{40}$ AGIER, M. Antropologia da cidade: lugares, situações, movimentos. São Paulo: Terceiro Nome, 2009 , p. 44.

41 Apropriamo-nos do procedimento da "observação participante", delineada originalmente por Malinowsky, na qual articula-se não mera observação de uma realidade em análise, mas também participação efetiva no cenário estudado. In: MALINOWSKY, B. Argonautas do Pacifico ocidental: um relato do empreendimento e da aventura dos nativos no arquipélago da Nova Guiné melanésia. $2^{\mathrm{a}}$ ed. São Paulo: Abril Cultural, 1978.

${ }^{42}$ GALLO, S. Em torno de uma educação menor. Educação e Realidade, Porto Alegre, v. 27, n. 2, 2002, p. 170.

${ }^{43}$ RICCIARDI, G. Espaço biográfico e literatura. In: CAIRO, L. R. et. Al (org.). Visões poéticas do espaço. Assis: Editora UNESP, 2008, p. 111.

${ }^{44}$ MARTENS, E. A questão de Sócrates: uma introdução. Trad. Vicente Sampaio. São Paulo: Editora Odysseus, 2013, p. 90.

${ }^{45}$ GALLO, Op. Cit., 2002, p. 173.
} 
Fernandes, localizada, à época, na Escola Estadual Professor Emydio de Barros ${ }^{46}$, zona oeste da Capital.

Durante o correr desses anos, o Cursinho muda suas instalações para o prédio da Faculdade de História da Universidade de São Paulo, desvincula-se da Rede Emancipa e se torna para nós um local de pertencimento quase irresistível, lembrando-nos muito do que conta o professor Gérard Lebrun ${ }^{47}$ no prefácio ao seu Passeios ao Léu ${ }^{48}$ : sempre que o avião que o trazia de Paris começava a sobrevoar a Capital paulista, era forçado a reconhecer a verdade da teoria de Aristóteles sobre o "lugar natural", aquele que seria mais agradável, mais orgânico aos corpos sensíveis da natureza. Sem isso, os locais de ensino ou não, são apenas prédios comuns.

O marco metodológico escolhido para orientar nosso olhar nesse percurso foi a abordagem qualitativa do Estudo de Caso, "uma investigação empírica de um fenômeno contemporâneo dentro de um contexto da vida real" 49 mediada pela "observação participante, apoiada pelas entrevistas". ${ }^{50}$

Em tais casos, temos de maneira especial o "ambiente natural como fonte direta de dados e o pesquisador como principal instrumento" ${ }^{51}$, claro que debruçar-se sobre um tema com o qual se tenha um estreito vínculo pessoal, suscita sempre crítica e autocrítica: "será possível ver de fora aquilo que se viveu por dentro?". 52

Todavia, a objetividade analítica requerida para a apreciação do tema foi

[...] garantida pela utilização de várias fontes de evidencias, sendo que a significância dos achados terá mais qualidade ainda se as técnicas forem distintas. A convergência de resultados advindos de fontes distintas oferece um excelente grau de confiabilidade ao estudo, muito além de pesquisas orientadas por outras estratégias. O processo de triangulação garantirá que descobertas em um Estudo de Caso serão convincentes e acuradas, possibilitando um estilo corroborativo de pesquisa. ${ }^{53}$

\footnotetext{
${ }^{46}$ Endereço: Avenida Nossa Senhora da Assunção, 292, Jardim Bonfiglioli, São Paulo.

47 Convidado a ocupar a cátedra de filosofia mantida na década de 60 pelo governo francês na Universidade de São Paulo, Lebrun alternava seus semestres letivos entre Aix em Provence e São Paulo.

${ }^{48}$ LEBRUN, G. Passeios ao léu. São Paulo, Brasiliense, 1983.

${ }^{49}$ YIN, R. K. Estudo de caso: planejamento e métodos. $2^{\text {a }}$ ed. Porto Alegre: Bookman, 2001, p. 32.

${ }^{50}$ AMADO, João (org.). Manual de investigação qualitativa em educação. Portugal: Universidade de Coimbra, 2014, p. 132.

${ }^{51}$ BOGDAN, R. C.; BIKLEN, S. K. Investigação qualitativa em educação. Porto: Porto, 1994, p. 134.

52 FÁVERO, O. Uma pedagogia da participação popular: análise da prática educativa do MEB (1961/1966). Campinas: Autores Associados, 2006, p. 12.

${ }^{53}$ MARTINS, G. A. Estudo de caso: uma estratégia de pesquisa. $2^{\text {a }}$ ed. São Paulo: Atlas, 2008, p. 80.
} 
Também a imagem-conceito abaixo ilustra essa utilização e cruzamento de fontes variadas no método do Estudo de Caso:

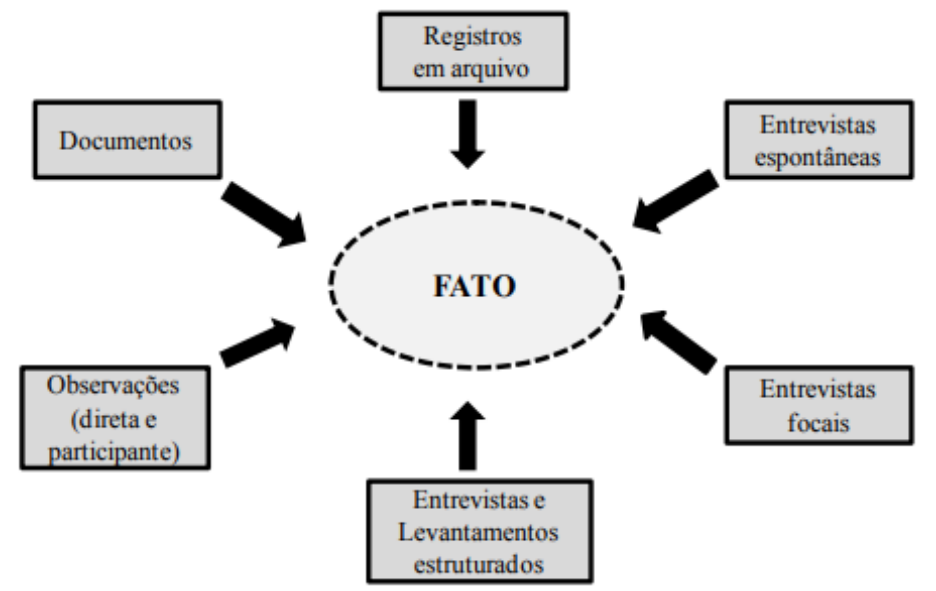

Figura 1 - Inserir legenda

Fonte: YIN, R. K. Estudo de caso: planejamento e métodos. $3^{\mathrm{a}}$ ed. Porto Alegre: Bookman, 2005, p. 127.

A despeito da crítica à metodologia escolhida vemos que essa [...] "configura-se como um conhecimento que encontra em nossa experiência porque é mais vivo, concreto e sensório do que abstrato" 54 . Do mesmo modo, "as experiências estão enraizadas num contexto, assim também o conhecimento nos estudos de caso. Esse conhecimento se distingue do conhecimento abstrato e forma derivado de outros tipos de pesquisa". ${ }^{55}$

As entrevistas colhidas amparam a compreensão de alguns dos matizes de nossa pesquisa, não obstante, como adverte nos Meunier no prefácio às Entrevistas do Le Monde, a entrevista não se confunde com a obra, sendo antes "uma entrada, um convite" 56 , para complementá-las, trouxemos essa multiplicidade e interação de fontes a que alude o gráfico, materializadas no registro de documentos internos do Cursinho (grade horária, manuais do aluno e do professor, Carta de Princípios), nas entrevistas focais, nos depoimentos, observações diretas e na própria bibliografia do tema.

Para remontar ao histórico e antecedentes do Cursinho delineados no primeiro capítulo, entrevistamos um dos fundadores da Rede Emancipa em São Paulo, Professor Maurício Costa e o Professor Gilberto Alvarez Giusepone Júnior, presidente do Grêmio Politécnico (19941996), diretor do DCE - USP (1997) e representante discente no Conselho Universitário da

\footnotetext{
${ }^{54}$ ANDRÉ, M. E. D. A. Estudo de caso em pesquisa e avaliação educacional. Brasília: Editora Liber Livros, 2008. Série Pesquisa, v. 13, p. 17.

${ }^{55}$ Ibid., p. 17.

${ }^{56}$ BALANDIER, G. et al. Civilizações - Entrevistas do Le Monde. Trad. Sérgio Flaksman. São Paulo: Ática, 1989, p. 8.
} 
USP (1997) e o Professor Waldir Cauvilla, da Faculdade de Educação da USP, sobre os anos de vivência no Cursinho do Grêmio da Faculdade de Filosofia.

Para o alicerce dos capítulos dois (2.3 - "Perfil docente" e 2.4 - "O Estudante: vulnerabilidade e descoberta de direitos") e três (3.2 "Provocações: Filosofia no res do chão") foram entrevistados 13 professores e 72 alunos, majoritariamente durante o ano de 2017 e primeiro semestre de 2018.

\subsection{Práxis e enfrentamentos imediatos}

Chama-se projétil a qualquer sólido pesado que se move no espaço, abandonado a si mesmo após haver recebido impulso.

Discurso do espetáculo Projeto Brasil, texto e direção de Marcio Abreu (Companhia Brasileira de Teatro).

Pensar a Educação a partir da vivência de um Cursinho Popular traz-nos a certeza de que a verdadeira pedagogia democrática não existe sozinha. É a junção de vários elementos em sintonia $^{57}$ de um "ímpeto arrasador e ao mesmo tempo construtor" 58 da realidade social e das práticas pedagógicas.

O Cursinho Popular movimento de educação não-formal de natureza voluntária ${ }^{59}$, é um novo sujeito social coletivo e político que surge, como "todo movimento social, para

\footnotetext{
${ }^{57}$ Pensar nesses vários elementos que se entrecruzam em harmonia para a consecução de um objetivo faz-nos lembrar citação de Inojosa: "A rede de compromisso social é aquela que se tece com a mobilização de pessoas físicas e ou jurídicas, a partir da percepção de um problema que rompe ou coloca em risco o equilíbrio da sociedade; ou as perspectivas de desenvolvimento social. Esta percepção ampliada da sociedade atrai estas pessoas para articular-se em função de um proposito comum e as leva a definir, em conjunto, um objetivo em comum, capaz de ser realizado através dessa sua articulação, com a preservação da identidade original de cada participante”. In: INOJOSA, R. M. Redes de compromisso social. Revista de Administração Pública, Rio de Janeiro, v. 3, n. 5, 1999, p. 120.

${ }^{58}$ SARAMAGO, J. Prefácio. In: MÃE, Valter Hugo. O remorso de baltazar serapião. $2^{\mathrm{a}}$ ed. Rio de Janeiro: Biblioteca Azul, 2018, p. 11.

${ }^{59}$ A respeito da natureza do trabalho voluntário dos cursinhos que funcionam nas Universidades, expressa Boaventura Santos: "É preciso evitar que ela seja orientada para atividades rentáveis com o intuito de arrecadar recursos extra-orçamentários. Nesse caso, estaremos perante uma privatização discreta (ou não tão discreta) da universidade pública para evitar isso, as atividades de extensão devem ter como objetivo prioritário [...] o apoio solidário na resolução dos problemas da exclusão e da discriminação sociais e de tal modo que nele se dê voz aos grupos excluídos e discriminados". In: SANTOS, B. S. de. A universidade no século XXI: para uma reforma democrática e emancipatória da universidade. Disponível em <http://www.ces.uc.pt/bss/documentos/auniversidadedosecXXI.pdf $>$. Acesso em 10 fev. 2017.
} 
transcender modalidades restritas de luta, e colocar em xeque as fontes da autoridade, modificando as regras do jogo que sustentam a legitimidade dos processos decisórios". ${ }^{60}$

Partindo da obra de Von Simson, em sua análise sobre a natureza da educação nãoformal, singularizamos:

A educação não-formal caracteriza-se por ser uma maneira diferenciada de trabalhar com a educação paralelamente à escola [...]. A transmissão do conhecimento acontece de forma não obrigatória e sem a existência de mecanismos de repressão em caso de não aprendizado, pois as pessoas estão envolvidas no e pelo processo ensino-aprendizagem e tem uma relação prazerosa com o aprender. [...] As atividades de educação nãoformal precisam ser vivenciadas com prazer em um local agradável, que permita movimentar-se, expandir-se e improvisar, possibilitando oportunidades de troca de experiências, de formação de grupos (de proximidade, de brincadeiras e de jogos, no caso das crianças e 40 jovens), de contato e mistura de diferentes idades e gerações [...]. A educação não-formal considera e reaviva a cultura dos indivíduos nela envolvidos, incluindo educadores e educandos, fazendo com que a bagagem cultural de cada um seja respeitada e esteja presente no decorrer de todos os trabalhos, procurando não somente valorizar a realidade de cada um, mas indo além, fazendo com que essa realidade perpasse todas as atividades. [...] Os espaços de educação nãoformal deverão ser desenvolvidos seguindo alguns princípios como: apresentar caráter voluntário, proporcionar elementos para a socialização e a solidariedade, visar ao desenvolvimento social, evitar formalidades e hierarquias, favorecer a participação coletiva, proporcionar a investigação e, sobretudo, proporcionar a participação dos membros do grupo de forma descentralizada.[...] Faz-se necessário garantir a construção de um vínculo afetivo entre as partes que participam desta proposta visando à elaboração de práticas significativas para a população envolvida. As práticas educativas, nessa linha, costumam utilizar e explorar as mais diversas formas de linguagem e expressão: corporal, artística, escrita, teatral, imagética, envolvendo, por exemplo, áreas ligadas ao meio ambiente, ciências naturais e lógico-matemáticas. Nessa multiplicidade de práticas, encontram-se maneiras de se reelaborarem a valorização e a auto-estima da população com a qual se trabalha, fornecendo uma pluralidade de possibilidades de comunicação e, assim, abrindo-se 'canais' para a expansão e a explicitação de sentimentos, emoções e desejos. (ênfase nossa $)^{61}$

Segundo Castro,

embora os Cursinhos Populares sejam um fenômeno recente, eles têm suas raízes em ações e projetos que datam de pelo menos meio século. Ao longo desse período, o acúmulo de experiências na tentativa de superar as

${ }^{60}$ KOWARICK, L. Cortiços: reflexões sobre humilhação, subalternidade e movimentos sociais. In: KOWARICK, L.; FRÚGOLI JR, H. (org.). Pluralidade urbana em São Paulo: vulnerabilidade, marginalidade, ativismos. São Paulo: Editora 34, 2016, p. 190.

${ }^{61}$ VON SIMSON, O. R.; PARK, M. B.; FERNANDES, R. S. (Org.). Educação não-formal: cenários da criação. Campinas: Ed. Unicamp, 2001, pp. 9-13. 
dificuldades impostas pelo sistema de vestibular esteve entre as principais motivações dos Cursinhos Populares. ${ }^{62}$

A dimensão política e pedagógica desses coletivos, ainda que heterogêneos, assemelham-se em certas características, resumidas na dialética da preparação para o vestibular com temas para uma leitura crítica da sociedade e para a educação da cidadania, na construção de uma nova consciência das questões sociais ${ }^{63}$, na ocupação e legitimação dos espaços sociais, passando por "seminários, fóruns de discussões, assembleias, negociação de isenções e bolsas com universidades, ações judiciais, formulação de propostas para facilitar o acesso e a permanência de estudantes das classes populares no ensino superior e democratizar a educação e o acesso ao conhecimento". ${ }^{64}$

Trazendo, nas palavras de Santos,

[...] um tensionamento crucial para a possibilidade de avanço em torno deste projeto, que é a fricção entre duas intenções que, em alguns casos conseguem ser compatíveis, mas que em geral não conseguem convergir: o confronto entre a politização pedagógica do trabalho que se efetiva nos pré-vestibulares e a necessidade de preparação para o vestibular - que muitos chamam de "adestramento" para fazer as provas. ${ }^{65}$

Animados pela "emergência na década de 1990 de valores como solidariedade e participação, como contrapontos à emergência de ordens e comandos emanados pela onda neoliberal que criam um substrato social profícuo para iniciativas baseadas no voluntariado"66 os pré-vestibulares sociais despontam nesse contexto, buscando conjugar, nas palavras de Ribeiro: [..] "a humanização, afirmada por Freire, com a emancipação, pensada por Marx"

${ }^{62}$ CASTRO, C. A. Cursinhos alternativos e populares: movimentos territoriais de luta pelo acesso ao ensino público superior no Brasil. Presidente Prudente, 2005. Dissertação (Mestrado em Geografia) Faculdade de Ciências e Tecnologia, Universidade Estadual Paulista, p. 54.

${ }^{63}$ A Professora Maria Clara Di Pierro esclarece-nos que: “[...] No aspecto ético, a educação popular se inscreve entre as correntes libertárias do pensamento social moderno que rejeitam a exploração e alienação e nutrem a utopia de uma sociedade igualitária. Consequentemente, as práticas de formação humana iluminadas por esse paradigma se orientam pelos valores da liberdade, da justiça e do respeito à diversidade." In: DI PIERRO, M. C. Tradições e concepções de educação de jovens e adultos. In: CATELLI JR., Op. Cit., 2017, p. 17.

${ }^{64}$ NASCIMENTO, A do. Universidade e cidadania: o movimento dos cursos pré-vestibulares populares. Lugar Comum: Estudos de Mídia, Cultura e Democracia, Rio de Janeiro, n. 17, 2002, p. 40.

${ }_{65}$ SANTOS, R. E. Pré-vestibulares populares: dilemas políticos e desafios pedagógicos. In: CARVALHO; ALVIM FILHO; COSTA, Op. Cit., 2005, p. 195.

${ }^{66}$ SANTOS, R. E. Pré-vestibulares Populares: dilemas políticos e desafios pedagógicos. In: CARVALHO; ALVIM FILHO; COSTA, Op. Cit., 2005, p. 190.

${ }^{67}$ RIBEIRO, M. Exclusão e educação social: conceitos em superfície e fundo. Educ. Soc., Campinas, v. 27, n. 94, 2006, p. 156. 
Nesse momento, toma forma [...] "um deslocamento da visibilidade para as organizações não governamentais. As identidades coletivas dos movimentos populares deixaram as contestações de lado, dando ênfase a um nível mais operacional e propositivo." ${ }^{\circ 8}$ É também a partir dos anos 1990, que a ampliação da demanda das camadas populares pelo ingresso no ensino superior, catalisa a organização de movimentos sociais que pudessem auxiliar na construção e na conquista desse direito. ${ }^{69}$

Saffioti conta-nos que

O primeiro cursinho popular de que se tem notícia surgiu em 1962, era ligado à Faculdade de Filosofia da USP e tinha como objetivo estender o acesso ao Ensino Superior as camadas de menor poder econômico da população. Nas décadas de 70 e 80, surgiram experiências assim por todo o Brasil. Porém, em estudo feito recentemente sobre cursinhos populares existente na cidade de São Paulo, Bacchetto (2003) afirma que foi só na década de 90 que houve um grande aumento do número de cursinhos alternativos na cidade. Até 1992 havia apenas um cursinho popular em funcionamento e a duplicação dos egressos do Ensino Médio nas Escolas Públicas aumentou a demanda por preparação para os vestibulares para as classes pobres. A procura indiscriminada pelo Ensino Superior, entre estudantes de baixa renda, está geralmente associada com a busca por algum lugar no mercado de trabalho: o diploma universitário, independentemente da graduação escolhida, opera por si mesmo. Noutros casos, para os já integrados ao mercado, o Ensino Superior é visto como possibilidade de uma melhor posição ocupacional, ou seja, como fator de "ascensão social". ${ }^{70}$

A respeito do Cursinho aludido, dito Cursinho do Grêmio, conversamos com o Professor Waldir Cauvilla, da Faculdade de Educação da USP, professor de História e Conhecimentos Gerais no período de 1966 a 1973 deste Cursinho, que contou-nos os detalhes dessa experiência:

Comecei a dar aulas no Cursinho do Grêmio da Faculdade de Filosofia, em 1966. As coisas correram normalmente até final de 67...últimos meses de 67. Se fosse em fins de 68 , acho que as coisas teriam acontecido de outro modo ou nem acontecido.

A diretoria do Cursinho era nomeada pela Direção do Grêmio. Quando mudava a direção do Grêmio, mudava também a do Cursinho. Era elaborada uma listra tríplice, ratificada pela direção do Grêmio. Um nome recorrente na direção era o Jocimar Archângelo, que vinha fazendo um trabalho bom e o cursinho vinha crescendo. O cursinho funcionava fora da USP, tinha três unidades, nas ruas Albuquerque Lins e Martim Francisco e na Praça Carlos Gomes, na Liberdade. Eu dava aula na Liberdade. A fama do cursinho sempre esteve ligada à área de humanas, era um referencial. Marca uma filosofia

${ }^{68}$ FACEIRA, L. S. O ProUni como política pública em suas instâncias macroestruturais, mesoinstitucionais e microssociais: pesquisa sobre a sua implementação pelo MEC e por duas universidades na região metropolitana do Rio. Rio de Janeiro, 2009. Tese (Doutorado em Educação) - Pontifícia Universidade Católica, p. 45.

${ }^{69}$ MENDES, T. C. Cursinhos populares pré-universitários e educação popular: uma relação possível? 2011, p. 2. Disponível em <https://redeemancipa.org.br/2011/05/343/>. Acesso em 12 ago. 2017.

${ }^{70}$ SAFFIOTI, Op. Cit., 2008, p. 36. 
diferente na área docente, porque os professores do Anglo e do Objetivo, os outros cursinhos grandes da época, eram homens ligados à medicina, à engenharia. Essa á grande diferença, no Cursinho do Grêmio, os professores vinham da Física, da História, da Biologia, então, tinham uma perspectiva pedagógica. A aula era diferente, isso é uma marca muito importante. Nos fins de semana sempre passavam um filme e um professor era escalado para comentar e debater depois. Era uma ênfase grande na parte cultural, não só ficar nisso de passar no vestibular.

$\mathrm{Na}$ transição da presidência para o Bernardino Figueiredo, aconteceu a ruptura. Quando ele assumiu, ele foi no sábado tomar o Cursinho, trocando as pessoas. Só não foi no prédio da Rua Martim Francisco, que foi pra onde nós, dissidentes nos reunimos para resistir e tentar segurar o Cursinho, ficamos lá dia e noite! Fomos até para as ruas desviar os alunos para que não fossem para as outras unidades, concentrando todos na Martim Francisco. Mas era uma situação ruim e decidimos entregar o Cursinho ao Grêmio e fundar o "Equipe", fomos para um prédio na Rua Imaculada Conceição, em Santa Cecília, na mesma linha de trabalho. Mais cultural, conservando a fama de referência na área das Humanas, mas com um corpo docente muito bom nas outras áreas também. A elite da esquerda da época colocava os filhos lá. Eu fiquei lá até 73. Tínhamos um material apostilado que cada professor mesmo fazia, dentro da ideia do que na época era uma apostila (Anexo 1). E a relação com os alunos era muito boa, não tínhamos barreira para com os alunos, pra conversar. Mas o máximo de "público" que tinha era a concessão de algumas bolsas de estudos que concedíamos. ${ }^{71}$

\section{3 "Efeitos de lugar": o Cursinho no espaço urbano}

Depois de subir o morrinho, no adro, é paz. Paz existe no mundo, ligeira. Onde a gente dói? Na Justiça, acho!

Paulo Mendes Campos, Crônicas Escolhidas.

Há lutas que problematizam também os territórios nos quais se dá a disputa. Reeditam suas vulnerabilidades, atualizam o debate sobre a segregação e reprodução das desigualdades ${ }^{72}$, isso, porque naturalmente, a cidade [...] "não é um tipo de cenário neutro para a expansão das relações sociais. A qualidade do espaço construído inevitavelmente influencia a qualidade das interações sociais que lá acontecem". ${ }^{73}$

${ }^{71}$ CAUVILLA, W. Entrevista concedida a Stella Verzolla Tangerino. São Paulo, 8 jun. 2018.

${ }^{72}$ Interessante a reflexão de Harvey em Los límites del capitalismo y la teoria marxista: "A circulação do capital transforma, cria, sustenta e inclusive ressuscita certas infra-estruturas sociais a dispensa de outras. É difícil dizer como isto ocorre exatamente, mas a linha geral da interconexão é suficientemente clara. Elas têm que se apoiar nas mais valias, e sob o capitalismo isso significa que se apóiam na produção de mais valia”. In: HARVEY, D. Los límites del capitalismo y la teoria marxista. México: Fondo de Cultura Económica, 1999, p. 402.

${ }^{73}$ CALDEIRA, T. P. Cidade de muros: crime, segregação e cidadania em São Paulo. São Paulo: Editora 34, 2000, p. 302. 
O estudo de Peter Hall ${ }^{74}$ chega mesmo a colocar a "cidade" como um novo ator coletivo. Sendo a cidade o locus do Cursinho, sua expressão, essencialmente urbana e uma de suas propostas passar justamente pela reinvenção dessa experimentação da cidade ${ }^{75}$ por aqueles aos quais o acesso foi historicamente negado, temos o interesse renovado em problematizarmos a estrutura urbana na qual se entrecruzam as vivências dos atores do Cursinho, geografia que não raro, reafirma [...] "o sentimento de que grupos diferentes pertencem a universos separados e têm reinvindicações irreconciliáveis"76, como referência Castel: "O processo pelo qual uma sociedade expulsa alguns de seus membros obriga a que se interrogue sobre o que, em seu centro, impulsiona essa dinâmica. É essa relação encoberta do centro com a periferia que se deve agora tentar fazer aparecer". ${ }^{77}$

Nas palavras de Gadotti:

Precisamos de uma pedagogia da cidade para nos ensinar a olhar, a descobrir a cidade, para poder aprender com ela, dela, aprender a conviver com ela. A cidade é o espaço das diferenças. A diferença não é uma deficiência. É uma riqueza. Existe uma prática da ocultação das diferenças, também decorrente do medo de ser tocado por elas, sejam as diferenças sexuais, sejam as diferenças culturais etc. Em geral, a nossa pedagogia dirige-se a um aluno médio, que é uma abstração. O nosso aluno real, contudo, o aluno concreto, é único. Cada um deles é diferente e precisa ser tratado em sua individualidade, em sua subjetividade. Uma pedagogia da cidade serve também para a escola construir o projeto político-pedagógico de uma "educação na cidade". ${ }^{78}$

Conforme provocação de Bourdieu no capítulo "Efeitos de lugar" de seu Miséria do mundo ${ }^{79}$ traduzido por Borges e Carvalho, "o espaço social se retraduz no espaço físico, exprimindo as hierarquias e distancias sociais e interferindo sobre a disponibilidade e distribuição de bens públicos e privados e sobre as oportunidades de sua apropriação por

\footnotetext{
${ }^{74}$ HALL, P. A. The movement from keynesianism to monetarismo: institucional analysis and British economic policy in the 1970s. In: STEINMO, S.; THELEN, K.; LONGSTRETH, F. (org.). Structuring politics. Oxford: Cambridge University Press, 2010, p. 90-113.

${ }^{75}$ Notadamente em relação à cidade de São Paulo, Sérgio Adorno ilustra-nos que "[...] o território da capital paulista desdobra-se em várias "São Paulos". Esse território é altamente heterogêneo, com desiguais características e situações econômicas, demográficas, sociais e criminais, indicativas de condições de vida e de mortalidade distintas", cf. ADORNO, S.; NUNES, C.; BATISTA NERY, M. A cidade e a dinâmica da violência. In: KOWARICK, L.; FRUGOLI JR., H. (org.). Pluralidade urbana em São Paulo: vulnerabilidade, marginalidade, ativismos". São Paulo: Editora 34; FAPESP, 2016, p. 389.

${ }^{76}$ CALDEIRA, Op. Cit., 2000, p. 340.

${ }^{77}$ CASTEL, Op. Cit., 1998, p. 143.

${ }^{78}$ GADOTTI, M. A escola na cidade que educa. Cadernos CENPEC, São Paulo, n. 1, 2006, p. 139.

${ }^{79}$ BOURDIEU, P. Efeitos de lugar. In: BOURDIEU, P. (Org.). A miséria do mundo. Petrópolis: Vozes, 1997.
} 
diferentes grupos e classes sociais" $" 80$. Caldeira mostra-nos também que [...] "os movimentos sociais influenciaram a ação da administração local não só na criação de serviços públicos e de infra-estrutura urbana, mas também na transformação do status legal da periferia". ${ }^{81}$

Bourdieu identifica que na cena urbana,

A capacidade de dominar o espaço, sobretudo aproximando-se (material ou simbolicamente) de bens raros (públicos ou privados) que se encontram distribuídos, depende do capital que se possui. [...] A posse de capital assegura, além disso, a quase ubiquidade que torna possível o domínio econômico e simbólico dos meios de transporte e de comunicação - e que é muitas vezes reduplicada pelo efeito da delegação, poder de existir e agir à distancia através de um preposto.

Inversamente, os que não possuem capital são mantidos a distancia, seja física, seja simbolicamente, dos bens socialmente mais raros e condenados a estar ao lado das pessoas ou dos bens mais indesejáveis e menos raros. A falta do capital intensifica a experiência da finitude, ela prende a um lugar. ${ }^{82}$ (ênfase nossa)

A distribuição espacial dos equipamentos de saúde, lazer e educação no cenário metropolitano paulista sempre obedeceu à logica da concentração de renda ${ }^{83}$. Se como contanos Seabra, "a cidade chegou a ser promessa de um mundo melhor porque dela foi veiculada para a sociedade inteira uma imagem de mundo com novas possibilidades" ${ }^{84}$, indiscutível que o [...] "pêndulo" do Estado pende para o capital ao compararmos a qualidade dos serviços públicos existentes nas regiões centrais e nas periferias ${ }^{85}$. Isso porque, "[...] assim como o capitalismo divide o tempo do trabalhador em "tempo de trabalho" e "tempo de viver", assim também divide a cidade no espaço do trabalho e espaço de viver, destinado à habitação e ao atendimento das necessidades básicas do homem". ${ }^{86}$

\footnotetext{
${ }^{80}$ BORGES, A.; CARVALHO, I. Revistando os efeitos de lugar: segregação e acesso ao mercado de trabalho em uma metrópole brasileira. Cad. CRH, Salvador, 1, v. 30, n. 79, 2017, p. 121. Disponível em: $<$ http://dx.doi.org/10.1590/s0103-49792017000100008>. Acesso em 4 dez. 2017.

${ }^{81}$ CALDEIRA, Op. Cit., 2000, p. 239.

${ }^{82}$ BORDIEU, Op. Cit., 2007, p. 163-164.

${ }^{83}$ Singer lembra-nos que "Na configuração urbana típica, o centro metropolitano é formado por um conjunto de serviços de controle - atividades políticas (executivas, legislativas, judiciais), religiosas, financeiras, sindicais, de informática, fiscais etc - ao redor das quais organizam outros serviços que atendem necessidades da população (escolas, hospitais, cinemas, centros de cultura e de lazer". In: SINGER, P. A economia dos serviços. Novos Estudos - CEBRAP, São Paulo, v. 2, n. 24, 1989, p. 129. ${ }^{84}$ SEABRA, O. C. de L. Territórios do uso: cotidiano e modo de vida. Cidades, São Paulo, v. 2, n. 2 , 2004, p. 181.

${ }^{85}$ CASTRO, Op. Cit., 2005, p. 69.

${ }^{86}$ VÉRAS, M. P. B. Segregação e alteridade na metrópole: novas e velhas questões sobre cortiços em São Paulo. In: KOWARICK; FRÚGOLI JR., Op. Cit., 2016, p. 116.
} 
O mapa abaixo mostra-nos como a densidade populacional de São Paulo não reflete a distribuição dos equipamentos urbanos e bens simbólicos, não somente aqueles de educação e cultura, mas também de saúde e postos de trabalho. "O que se revela é uma cidade desequilibrada onde há uma baixa correspondência entre crescimento urbano e a distribuição dos equipamentos culturais". ${ }^{87}$

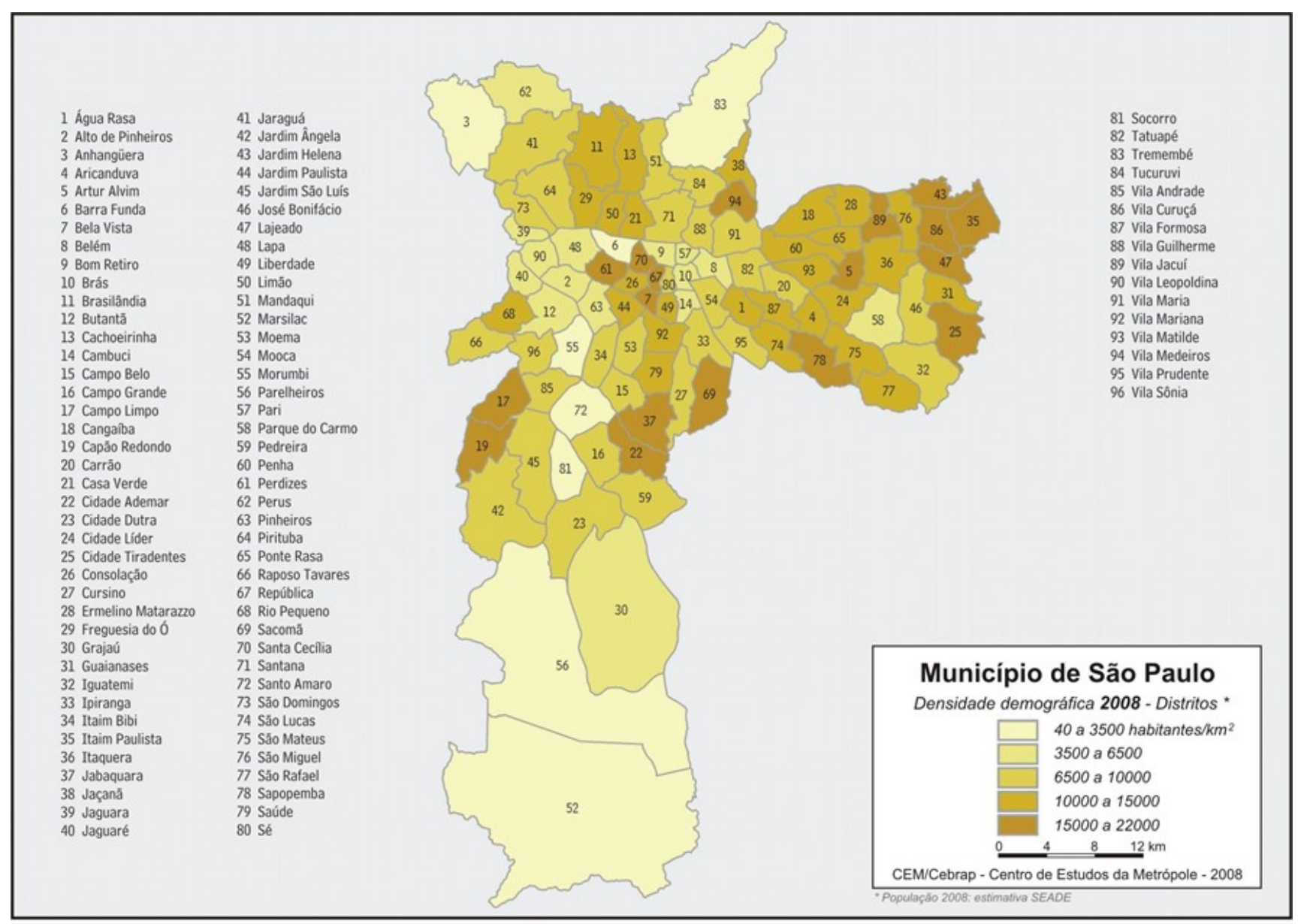

Gráfico 1 - Distribuição equipamentos urbanos por área no município de São Paulo Fonte: Centro de Estudos da Metrópole - CEBRAP (2008)

É oportuna a análise de Borges e Carvalho:

No campo da educação, por exemplo, investigações efetuadas em diversos países constataram a tendência das escolas públicas de se diferenciarem conforme a composição da área onde estão localizadas, com sérias desvantagens para aquelas que servem aos moradores das áreas pobres da cidade. No Brasil e na América Latina, estudos como os de Burgos (2009), Ribeiro e Katzman (2008), Flores (2006) ou Ribeiro et al. (2010) têm comprovado essa realidade. Com isso, essas escolas não conseguem propiciar

${ }^{87}$ BOTELHO, I. Os equipamentos culturais na cidade de São Paulo: um desafio para a gestão pública. Espaço e Debates, São Paulo, n. 43-44, 2004, p. 1. 
a seus alunos a aprendizagem e o avanço necessário para o alcance de credenciais educacionais exigidas crescentemente para a conquista de melhores condições no mercado de trabalho. ${ }^{88}$

Assim, a compreensão de como o espaço refletirá na Educação e na educação do Cursinho demanda noção de contexto. Contexto esse, diz nos Menenguello citando Agnew, “[...] que não é um produto geográfico de processos não espaciais de escolhas políticas, mas processos especializados de influência e escolha política". ${ }^{89}$

Não obstante, a materialidade do lugar, mais do que o acontecer histórico, estabelece a identidade que o sujeito irá definir com essa realidade, mediada por símbolos e unindo-se a uma pluralidade de sentidos e sentimentos, como pudemos ver nos depoimentos de alunos. No nosso estudo, essa "vivência do cursinho popular e a opção pela universidade pública não se restringem à busca por uma melhoria da formação, mas possuem uma dimensão de ocupação dos espaços sociais que atua contra a ordem estabelecida". ${ }^{90}$

Para Lefebvre,

[..] os lugares tanto se opõem como se completam ou se reúnem o que introduz uma classificação por topias, (isotopias, heterotopias, utopias, quer dizer lugares contrastantes), mas também e, sobretudo, uma oposição altamente pertinente entre os espaços dominados e apropriados. ${ }^{91}$

Bem assim, "considerar o componente espacial da privação social implica o reconhecimento de que as "novas formas" de pobreza urbana envolvem uma crescente segregação espacial e menores oportunidades de mobilidade social". ${ }^{92}$

Viu-se que o espaço pedagógico para as práticas de educação popular nos moldes dos Cursinhos, é preferencialmente o do interior das Universidades, como projeto de extensão ou em escolas estaduais e municipais de bairros periféricos; tornando-se comum sua relação com outros movimentos sociais, como "o movimento estudantil, o movimento negro, e também as comunidades eclesiais de base"93. Maíra Tavares conta-nos que "essa matriz de influências acaba sendo entrecruzada pelo pensamento de Paulo Freire, seja por se tratar de uma

\footnotetext{
${ }^{88}$ BORGES; CARVALHO, Op. Cit., 2017, p. 121.

${ }^{89}$ AGNEW, J. Mapping Politics: how context counts in electoral geography. Political geography, v. 15, n. 2, pp. 129-46. Apud MENEGUELLO, R. Partidos e comportamento político na metrópole paulistana. In: KOWARICK; FRÚGOLI JR., Op. Cit., 2016, p. 275-276.

${ }^{90}$ SAFFIOTI, Op. Cit., 2008, p. 177.

${ }^{91}$ LEFEBVRE, H. La production de l'espace. Paris: Éditions Anthropus, 1971, p. 152.

${ }^{92}$ SÃO PAULO (Município). Secretaria de Assistência Social. Mapa da Vulnerabilidade Social da População da Cidade de São Paulo. São Paulo: Cebrap, SESC e SAS-PMSP, 2004, p. 12.

${ }^{93}$ ZAGO, N. Cursos Pré-vestibulares populares: limites e perspectivas. Perspectiva, Florianópolis, v. 26, n. 1, 2008, p. 153.
} 
modalidade de educação não-formal, seja pela crítica da "educação bancária", que não problematiza os problemas vividos pelos educandos com vistas à sua emancipação". 94

O Cursinho Popular Florestan Fernandes situa-se no interior da Universidade de São Paulo. Essa espacialidade traduz para os alunos esse valor simbólico a que aludimos; o "estar" fisicamente na USP remete também à proximidade simbólica com o ideal acalentado de efetivamente ser aluno da Universidade.

Bem assim, dentre os níveis de rompimento de barreiras proporcionados pelo universo do Cursinho na vida dos alunos vemos que o penetrar em um território tido como inacessível ${ }^{95}$ menos geográfica e mais simbolicamente, reveste-se de grande relevância para eles, pois é como se operasse, nas expressivas palavras do historiador De Certeau, uma espécie de “transgressão da lei do lugar, mantendo uma relação entre o visível e o invisível, o material e o imaterial, constituindo-se em variantes que retratam-se em projeções simbólicas e narrativas, as sombras da prática cotidiana [...]". ${ }^{96}$

A representação do "morrinho" do poema epigrafado é a definição simbólica, pelos alunos, de um local de amadurecimento intelectual, mas antes, de acolhimento, um lugar no qual após as angustias da semana é possível sentir-se bem.

No expressivo dizer de Costa, "o simbólico da paisagem permite também um êxodo conceitual"97, o que nitidamente se vê nas palavras da aluna Fernanda Lobato Cabral, 20 anos: “A ansiedade pra chegar sábado e a vontade de não ir embora mesmo depois de horas mostra bem qual a importância do CPFF. [...] lá encontrei casa, abrigo, aconchego, o que vale todo o esforço, porque a USP não tem um acesso tão fácil e a grana é curta...".98

Acerca dessa percepção subjetiva do local físico no imaginário dos alunos, destacamos,

As dimensões da condição juvenil, que viemos tratando até então, estão condicionadas ao espaço onde são construídas. Esse passa a ter sentidos próprios, transformando-se em lugar, em um espaço do fluir da vida, do

\footnotetext{
${ }^{94}$ MENDES, M. T. Cursinhos populares pré-universitários e educação popular: uma relação possível? Porto Alegre: Editora UFGRS, 2009. Fórum de Leituras Paulo Freire, v. 11, p. 3.

${ }^{95}$ Remetemo-nos a Carlos: “[...] o modo como o corpo transita nos espaços-tempos de realização da vida cotidiana permeados por acessos normatizados com produtos das cisões que marcam a vida em espaços diferenciados, submetidos à coação da propriedade privada do solo urbano, traz em seu âmago aquilo que nega essa situação". Cf. CARLOS, A. F. A. O poder do corpo no espaço público: o urbano como privação e o direito à cidade. GEOUSP - Espaço e Tempo, São Paulo, v. 18, n. 2, 2014, p. 474.

${ }^{96}$ DE CERTEAU, M. A invenção do cotidiano: artes de fazer. Petrópolis: Vozes, 1994, p. 161.

${ }^{97}$ COSTA, O. Memória e paisagem: em busca do simbólico dos lugares. Espaço e Cultura, Rio de Janeiro, n. 15, 2003, p. 2.

${ }^{98}$ CABRAL, F. Entrevista concedida a Stella Verzolla Tangerino. São Paulo, 21 fev. 2018.
} 
vivido, além de fornecer suporte e mediação para as relações sociais com sentidos próprios, o lugar como ancoragem para a memória, tanto a individual quanto a coletiva. Os jovens tendem a transformar os espaços físicos em espaços sociais, pela produção de estruturas particulares de significados. (ênfase nossa) ${ }^{99}$

Os questionários socioeconômicos aplicados na ocasião da matrícula dos dois semestres de 2017 trazem-nos dados acerca da habitação dos alunos, indissociáveis da estrutura e recorrência simbólica dos espaços da cidade: “a espacialização confirma as diferenciações sociais existentes que se tornam espaciais, sem deixar de ser sociais" afirma Ferreira. ${ }^{100}$

Em ambos os infográficos, vemos o predomínio de alunos egressos de partes da Zona Sul, seguido por partes das Zonas Oeste e Leste, em segundo e terceiro lugares respectivamente, no caso das Zonas Sul e Leste, localidades relativamente distantes da Cidade Universitária, no Butantã, evidencia-se a importância a que aludimos, dada pelos alunos, de frequentar um “cursinho na USP".

\title{
Em que zona/cidade você mora?
}

\section{8 respostas}

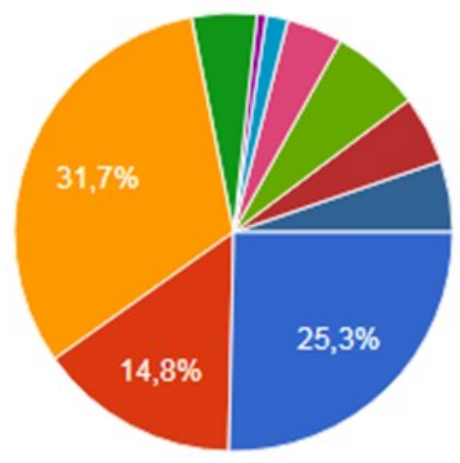

\author{
Zona Oeste \\ Zona Leste \\ Zona Sul \\ Zona Norte \\ Centro \\ ABC Paulista \\ Osasco \\ Taboão da Serra \\ $1 / 2$
}

Gráfico 2 - Em que zona/cidade você mora?

Fonte: Questionário socioeconômico - Matrícula para extensivo de janeiro de 2017

\footnotetext{
${ }^{99}$ DAYRELL, J.; CARRANO, P. Juventude e ensino médio: quem é este aluno que chega à escola? In: DAYRELL, J.; CARRANO, P.; LINHARES, C. M (org.). Juventude e ensino médio: sujeitos e currículos em diálogo. Belo Horizonte: Editora UFMG, 2014, p. 118-119.

${ }^{100}$ FERREIRA, I. C. B.; VASCONCELOS, A. M. N.; PENNA, A. N. Violência urbana: vulnerabilidade dos jovens da periferia das cidades. In: ENCONTRO NACIONAL DE ESTUDOS POPULACIONAIS, 16, 2008, Minas Gerais. Anais... Minas Gerais: Encontro Nacional de Estudos Populacionais, 2008, p. 18.
} 


\section{Em que região você mora?}

\section{8 respostas}
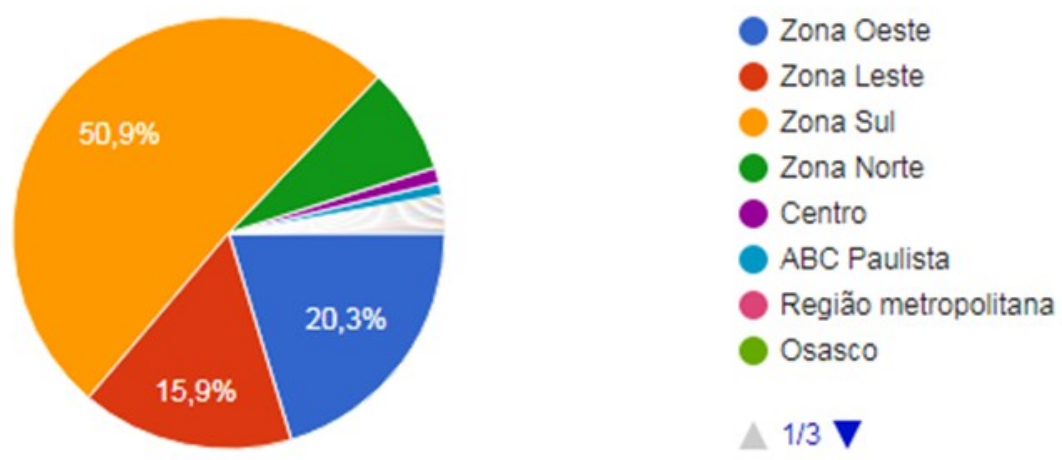

Gráfico 3 - Em que zona/cidade você mora?

Fonte: Questionário socioeconômico - Matrícula para extensivo de junho 2017.

\subsection{Antecedentes: O Cursinho da Poli}

Falar da experiência do Cursinho Popular Florestan Fernandes faz-nos remontar ao ano de 1987, ocasião em que começa a funcionar no prédio da Escola Politécnica da Universidade de São Paulo (USP) o Cursinho da Poli, experiência precursora ao que seria mais tarde o Emancipa, do qual deriva diretamente, nossa unidade em estudo, o Cursinho Florestan Fernandes. Sua gestão dividiu-se entre o Grêmio e a Escola Politécnica até 1992 e gratuitamente, "atendia anualmente cerca de 200 estudantes pré-universitários no período noturno". 101

A partir de 1996, “com o distanciamento paulatino do Grêmio Politécnico da vida cotidiana do projeto" ${ }^{102}$, o Cursinho sai do espaço universitário da USP, e passa a utilizar as instalações da Rua Alvarenga, no Butantã, zona oeste da Capital paulista. Posteriormente, amplia a capacidade de atendimento, produz seu próprio material didático e muda-se para a Rua MMDC, ainda no Butantã.

O periódico, O Politécnico, de 08 de agosto de 2001, informa-nos que em 1999,

10.000 candidatos faziam uma prova de conhecimentos gerais. Apenas 1250 candidatos passavam para a segunda fase, uma análise sócio-econômica. Selecionávamos por fim uma elite de 850 alunos carentes e bem informados. 9150 jovens ficavam do lado de fora. Entre eles os mais pobres e

${ }^{101}$ MENEZES, R. G. O movimento pelo resgate social do Cursinho da Poli e a criação da Rede Emancipa. In: ARELARO, L. G.; FRANÇA, G. C.; MENDES, M. T. (org.). Às portas da universidade: alternativas de acesso ao ensino superior. São Paulo: Xamã, 2012, p. 109.

${ }^{102}$ Ibid., p. 110. 
desinformados. O seu dinheiro gasto na inscrição para a prova do cursinho pagava parte do curso dos colegas que conseguiam entrar. ${ }^{103}$

Em entrevista a nós concedida em 20 de julho de 2017, o professor Gilberto Alvarez Giusepone Júnior ${ }^{104}$, presidente do Grêmio Politécnico em 1996, ano em que o Cursinho sai das dependências da USP e adquire outra configuração, conta-nos um pouco dessa história:

Em 1987 surge o Cursinho da Poli ${ }^{105}$, pequeno, dentro da própria USP, usando os espaços da USP. Ficamos lá até 1996 [...]. É uma história de embate político. [...] Tinha uma linha muito forte de politica de extensão universitária, uma responsabilidade para além de só "formar engenheiro para ser rico na vida". [...] Em 1994, tínhamos 800 vagas com 15 mil interessados. Fazíamos concursos para ingresso para dar conta dessa demanda, a seleção era feita em duas etapas, primeiramente a aplicação de uma prova e uma segunda análise com viés sócio-econômico. O problema era que com isso acabávamos selecionando somente a "elite da escola pública". Em 1997-98, tínhamos 8 mil alunos. Com a saída da USP e a negativa cursinhos comerciais em nos fornecer material, tivemos a urgência de criar o nosso próprio material pedagógico. Um expoente nessa empreitada foi André Miranda Leite, idealizador da Escola da Vida, que cria um projeto editorial inovador, que buscava propiciar reflexões e propor discussões interdisciplinares. Um grupo de professores de renome da USP supervisionou esse material didático, o PoliSaber. No ano 2000, da Rua Alvarenga vamos para a Rua MMDC e posteriormente para cá (Avenida Ermano Marchetti, 576) já com 8 mil alunos. Atualmente não temos mais o processo seletivo e atendemos uma média de 7 mil alunos/ano em três unidades: Lapa, Itaquera e Largo 13 (Santo Amaro). Somos o maior CP do Brasil. Mantido hoje por um instituto e uma Fundação (Polisaber), somos hoje uma ONG. 90\% dos nossos alunos são egressos da escola pública. Nossa mensalidade mais barata está na faixa de R $\$ 300 /$ mês, a mensalidade mais barata de Cursinho em São Paulo. Contamos com um departamento de serviço social e mediante critério sócio-economico concedemos bolsas e descontos. Temos também convênio com a FUNAP, através do qual atendemos alunos presos, autorizados a sair aos fins de semana.

Em artigo sobre a crise de identidade do Cursinho da Poli, Menezes destaca outro viés dessa dinâmica:

O Cursinho da Poli sempre se destacou pelo seu caráter não mercantil. No entanto, a partir de 1997 ele sofreu mudanças substanciais em sua estrutura, que desembocaram na apropriação privada de seu projeto social. Sua transferência para um edifício de 5 mil metros quadrados no bairro da Lapa em 2000, acirrou, dentro e fora dele, a discussão acerca de seu caráter social. $\mathrm{O}$ novo endereço passou a abrigar cerca de 8 mil alunos (uma expansão vertiginosa de $1000 \%$ em relação ao ano anterior) e saltou, no seguinte, para 15 mil vagas. Essa captura englobou a credibilidade social que o CP havia conquistado, bem como o uso do prestígio da maior universidade do país - a

${ }^{103}$ O Politécnico, São Paulo, número, 8 ago. 2001, p. 12.

${ }^{104}$ GIUSEPONE JR., G. A. Entrevista concedida a Stella Verzolla Tangerino. São Paulo, 20 jul. 2017.

${ }^{105}$ Nas décadas de 60/70, na chamada Poli velha, funcionava um cursinho que atendi alunos egressos das escolas públicas e preparava para o vestibular de exatas (MAPOFEI - Mauá, Poli e Fei). À época o vestibular era dividido entre o CESCEM (área médica e biológica), CESCEA (humanas) e MAPOFEI. 
USP. O coroamento dessa estratégia de apropriação ficou evidente em meados de 2004, quando a diretoria do CP iniciou os trâmites burocráticos para transformar o cursinho em fundação privada. Esse anúncio instalou um malestar no projeto. ${ }^{106}$

Em que pese as discussões sobre o desvirtuamento do caráter social do Cursinho da Poli, nas palavras de Demétrio Magnoli: “[...] a substituição da lógica social pela empresarial”107, inegável sua referência como experiência que "ecoa em todos aqueles que acreditam e lutam por outra forma de educação, de universidade e pela democratização do conhecimento e da sociedade". ${ }^{108}$

\subsection{Antecedentes: a Rede Emancipa - Movimento Social de Cursinhos Populares}

Ante o cenário de divergência com o Cursinho da Poli, pelo desvirtuamento do projeto original daquele Cursinho, que assumia agora feições comerciais, estrutura-se um processo de retomada a partir do movimento estudantil do Grêmio da Poli-USP.

A Carta aos Professores e direção do Cursinho da Poli (Anexo 02) subscrita por 29 professores em 17 novembro de 2004, deixa claro o propósito de repensar o movimento do Cursinho e seus rumos face à recente alteração da feição jurídica do coletivo, que passara a ser uma fundação privada com fins públicos. Destacamos o trecho que se segue:

Nós, proponentes abaixo assinados, apostamos na retomada das discussões de forma democrática e franca sobre os rumos do cursinho, na maneira mais adequada para enfrentar esses dilemas atuais. Sem retomarmos os alicerces do projeto de inclusão social e educacional tais dilemas só se aprofundarão. Retomar a tradição do Cursinho da Poli como parte do movimento social pela universidade pública, gratuita e de qualidade. Transformar o Cursinho da Poli num espaço público e democrático. Para isso precisamos superar coletivamente os entraves que tanto têm impedido esse diálogo.

Isso significa objetivamente: construir condições para oferecer vagas a um preço mais acessível e repensar o programa de bolsas no Cursinho da Poli, numa cidade que apresenta elevados índices de privação social ou, para usarmos a terminologia corrente, exclusão social. Promover a participação política de todos buscando contribuir na luta para transformar a cartografia da desigualdade social na cidade e não se tornar um agente de exclusão. Sabemos que não faltam dados qualificados para comprovar a situação de privação social vivida por mais da metade da população de São Paulo, praticamente entregue à própria sorte. ${ }^{109}$

\footnotetext{
${ }^{106}$ MENEZES, Op. Cit., 2012, p. 110.

${ }^{107}$ MAGNOLI, D. Tudo pelo social. Folha de S. Paulo, São Paulo, p. A-23, 3 mar. 2005. Disponível em $<$ http://www1.folha.uol.com.br/fsp/opiniao/fz0303200507.htm>. Acesso em 08 fev. 2018.

${ }^{108}$ MENEZES, Op. Cit., 2012, p. 118.

109 Carta aos professores e a direção do Cursinho da Poli, 17 nov. 2014. Disponível em $<$ https://midiaindependente.org/pt/red/2005/02/308174.shtml>. Acesso em 14 set. 2017.
} 
O professor Maurício Costa, um dos fundadores da Rede Emancipa, em entrevista a nós concedida ${ }^{110}$ relata que

[...] o projeto foi perdendo a identidade e alguns professores começaram a lutar pela retomada do projeto original, acarretando na demissão de alguns desses professores. Houve o apoio de grande parte dos alunos do Cursinho da Poli a esses professores demitidos e surgiram então dois projetos: o Cursinho do Grêmio da Poli-USP que foi uma tentativa de retomada do projeto original do Cursinho da Poli, pelo Grêmio e o outro que é a Rede Emancipa, um movimento social de educação popular, com sua primeira unidade na cidade de Itapevi, região metropolitana de São Paulo, que ficou até hoje.

\section{A Revista Cursinho Popular Emancipa - 10 anos educando para liberdade conta-nos} como foi o começo dessa primeira unidade da Rede, no município de Itapevi, periferia da região metropolitana de São Paulo:

Era um dia de inverno, clima seco, sol durante o dia e frio ao finalzinho da tarde e de noite...Um grupo de jovens se reúne numa padaria no centro da cidade. Eram em sua maioria estudantes universitários, mas havia também alguns professores, todos preocupados com a educação dos jovens da periferia. Como podia, numa cidade tão populosa como Itapevi, na periferia da Grande São Paulo, com tantos jovens, não haver nenhum projeto de educação popular para além do ensino básico?

No meio de devaneios e sonhos, inspirados pela discussão em curso sobre a formação da Rede Emancipa de cursinhos populares, fomos instigados a fazer nossa primeira experiência de um cursinho pré-universitário. A partir disso, só correria. Dezenas de reuniões nas lanchonetes, praças, shopping, salas e quartos das casas. Os professores correram atrás do lugar para o cursinho, os universitários atrás de mais professores e material didático. "Precisamos de um nome!" Depois da discussão e votação: "o nosso porta voz, o nosso estandarte será o maior ativista da questão ambiental no país: Chico Mendes". Um simples seringueiro que sonhou e ousou unir trabalhadores nos seringais com os índios, com os povos ribeirinhos, com os pescadores, com todos os povos da mata, em defesa do nosso verde, na defesa do nosso planeta. Nem tudo foi fácil. A incompreensão e as práticas da velha política em Itapevi fizeram com que a conquista de um espaço para o Cursinho demandasse muita luta.

No primeiro ano de existência, apesar de todo o apoio da comunidade e da direção da escola, tivemos que sair de onde estávamos por determinação da diretoria de ensino. Não nos abalamos. Fomos recebidos por dois anos em uma igreja até voltar a uma escola pública da qual, mais uma vez por força de negociatas da velha política tivemos que sair. Fizemos a experiência de alugar a nossa própria sede, contando com a mobilização incrível de todos pelo autofinanciamento principalmente dos estudantes. A força desse novo momento nos permitiu organizar, em 2013, um grande movimento que ocupou a prefeitura e, atendidos diretamente pelo prefeito, conseguimos finalmente

${ }^{110}$ COSTA, M. Entrevista concedida a Stella Verzolla Tangerino. São Paulo, 16 fev. 2018. 
abrir as portas da escola pública- onde estamos até hoje - para a nossa educação popular. ${ }^{111}$

No projeto político-pedagógico da Rede Emancipa, destacam-se os ideais da Rede e o empenho na

[...] construção de um amplo movimento de cursinhos populares préuniversitários para que milhares de jovens das periferias rurais e urbanas possam ingressar nas universidades, compartilhar e se apropriar do conhecimento aí desenvolvido e transforma-lo, dentro e fora deste espaço. As fronteiras deste projeto, contudo, se limitam à prova para ingresso no sistema de ensino superior. Se assim fosse, seria preciso deixar de lado uma ampla parcela da juventude pobre que conhece e se aproxima das iniciativas dos cursinhos populares. Queremos uma educação para os $99 \%$ da população brasileira e isso exige transformar a própria concepção de ensino - e de ensino universitário, em particular - e conecta-la a uma nova visão de nação, capaz de superar o sentido excludente das instituições, cultura e conhecimento vigente. Assim, entendemos e praticamos a educação popular como ferramenta político-pedagógica que tem como objetivo divulgar e recriar permanentemente o conhecimento como força material para transformar a sociedade. É uma concepção de formação comprometida com as necessidades das classes populares. Nesse sentido, ela deve, ao mesmo tempo, ser instrumento de mobilização, capacitação e estratégia de organização do povo em torno de seus próprios interesses, isto é, assumir o desafio de tornar comum o saber de uma estratégia de poder popular e construí-lo no cotidiano. $^{112}$

Nos dias atuais, a Rede Emancipa encontra-se presente em 19 cidades de 07 estados brasileiros, totalizando 32 cursinhos, com aproximados 5000 estudantes e cerca de 600 professores. ${ }^{113}$ É de uma dessas unidades que nasce o Cursinho Florestan Fernandes, objeto de nosso estudo, criado em 2007, inicialmente vinculado à Rede e após abril de 2016, em trajetória autônoma.

111 CHAVES, T.; MATA, A. In: Revista Cursinho Popular Emancipa - 10 anos educando para liberdade, São Paulo, 2017, p. 7-8.

112 Projeto político pedagógico da Rede Emancipa, enviado a nós via e-mail por Maurício Costa, professor e fundador da Rede.

${ }_{113}$ Dados obtidos no site da Rede. Disponível em < https://redeemancipa.org.br/institucional/quemsomos/>. Acesso em 11 jan. 2018. 


\section{CAPÍTULO 2: O Cursinho Popular Florestan Fernandes (CPFF)}

\subsection{Identidade e projeto pedagógico}

As pessoas são tão diferentes. Aprecio muito que o sejam. [...] Ser tudo igual é característica do azulejo na parede e, mesmo assim, há quem misture.

Valter Hugo Mãe, O paraíso são os outros. ${ }^{114}$

O Cursinho Florestan Fernandes, inicialmente uma das nove unidades de PréVestibulares da Rede Emancipa na Capital paulista nasce em 2007, da iniciativa associativa de Professores e ex-alunos dissidentes do Cursinho da Poli, fundado em 1987 e referência nacional na área de preparatórios populares, que não anuíam com a nova estratégia política desse Cursinho de cobrança de matrícula e material didático dos alunos.

Seus trabalhos, que acontecem desde então aos sábados, em período integral (das $8 \mathrm{~h} 30$ às 18h45), iniciaram-se a princípio às dependências da Escola Estadual Professor Emydio de Barros, sita à Avenida Nossa Senhora da Assunção, 292, Jardim Bonfiglioli, em São Paulo e a partir de março de 2014, no prédio da Faculdade de História da Universidade de São Paulo (USP), região do Butantã, zona oeste do município de São Paulo.

A concessão para ocupação e utilização de SEIS salas ${ }^{115}$ da Faculdade de História é autorizada mediante formulário preenchido no início de cada semestre pela coordenação do Florestan ao Diretor do Departamento de História, responsabilizando-se financeiramente por eventuais danos causados às salas requisitadas (Anexo 3). Muito embora haja esse amparo institucional por parte da USP, o Cursinho em comento não está vinculado diretamente a nenhuma atividade de extensão da Faculdade de História ou de outra unidade, limitando-se referido vinculo ao espaço físico das instalações.

De estrutura própria, o Cursinho conta apenas com um armário, doado pelo pai de um dos ex-professores, utilizado para guardar livros, materiais como giz, cabos para

\footnotetext{
${ }^{114}$ MÃE, V. H. O paraíso são os outros. São Paulo: Cosac Naify, 2014, p. 4.

${ }^{115}$ As salas recebem os nomes de mulheres que lutaram e destacaram-se nas Artes e Literatura como Carolina Maria de Jesus, Maria Firmina dos Reis, Lia de Itamaracá, Luana Hansen, Ana Maria Gonçalves, Raquel Trindade como se pode ver no Anexo n 05 (grade horária), prestando-lhes justa homenagem e incitando os alunos a que as conheçam melhor.
} 
computador/notebook, caixas de som, alguns medicamentos para necessidades básicas dos alunos.

A média de alunos que se matriculam e comparecem ao Florestan Fernandes é de 350 a 400 por semestre, sendo que, ao final desse período, esse número cai para 150 a 200, principalmente, no segundo semestre do ano, no qual o índice de evasão se acentua. Um dos fatores para a saída dos alunos é principalmente o desestímulo frente aos baixos resultados após prestarem o Exame Nacional do Ensino Médio (ENEM). Todavia, interessante anotar que se a evasão é um movimento presente na dinâmica do Cursinho, o retorno de ex-alunos no próximo ano letivo também se verifica, e em número expressivo.

Atualmente, seu quadro docente é formado por 40 professores, sendo 07 deles, também coordenadores, alunos que já concluíram ou ainda estão cursando a graduação ou pósgraduação de cursos da USP: História, Letras, Matemática, Geografia, Sociologia, Física, entre outros. A idade média dos professores fica entre 19-30 anos, sendo que atualmente temos dois professores fora dessa faixa, com 46 (João Paulo, de inglês) e 53 anos (Regina, professora de matemática).

Sobre a questão da problemática do compromisso docente Santos, analisa:

A dificuldade da maioria das iniciativas para arregimentar professores voluntários faz com que se trabalhe com todos aqueles que se apresentam como interessados, ou seja, na maioria dos cursos não há conjunto de critérios para aglutinação de novos militantes/colaboradores. Isto contribui para que (ao mesmo tempo em que é possibilitado pela) agregação de indivíduos que nem sempre concordam com os marcos ideológicos principais do movimento inicial (ou deles partilham), quais sejam, a discussão racial e as injustiças no mundo da educação. Os "prés" são replicados e difundidos, portanto, a partir da agregação de indivíduos que conformam, diante de suas diferenças e divergências, pactos ideológicos frouxos - e, diga-se de passagem, muitas vezes de fácil ruptura - vide alta rotatividade de professores, que caracteriza a maioria desses cursos. ${ }^{116}$

Em abril de 2016, essa unidade rompe com a Rede Emancipa e com sua Carta de Princípios, lança-se de modo autônomo sob a coordenação de sete professores, mantendo suas instalações na Faculdade de História. As justificativas para o desligamento relacionaram-se a divergências ideológicas no tocante à formulação da política da Rede, a qual não era construída em fóruns e espaços abertos de coordenação compostos por representantes das unidades e sim, por coordenadores integrantes do Movimento Esquerda Socialista (MES), inviabilizando a

\footnotetext{
${ }^{116}$ SANTOS, E. Pré-vestibulares Populares: dilemas políticos e desafios pedagógicos. In: CARVALHO; ALVIM FILHO; COSTA, Op. Cit., 2008, p. 193.
} 
disputa do movimento pela base. Nesse cenário, em que sugestões das unidades eram tidas como desnecessárias frente às linhas políticas formuladas previamente, as divergências acirraram-se, culminando na ruptura.

O entendimento da Coordenação do Florestan Fernandes à época era o de que não obstante a participação partidária nos movimentos sociais seja desejável, legitima e reflexo de um cenário democrático, sua construção, em lugar de políticas centralizadoras, deveria ser pensada coletivamente, tendo-se em vista as demandas reais e peculiaridades de cada unidade, conforme se nota na Carta do Cursinho Florestan em ruptura à Rede Emancipa (Anexo 4).

De outro lado, em entrevista a nós concedida, o professor Maurício Costa ${ }^{117}$, fundador da Rede Emancipa, indagado sobre a ruptura da unidade Florestan, acredita que algumas divergências metodológicas culminaram na retirada. "Divergências no sentido de fazer cursinho", explica,

de escolher entre ser um movimento social ou um cursinho. Os Cursinhos que se estruturam dentro dos espaços universitários acabam tendo uma configuração diferenciada, muitas vezes se nutrindo dos debates internos universitários. É bem difícil manter um ponto de contato, de convergência com todas as unidades da rede, cada uma delas com suas peculiaridades, heterogeneidade de professores e alunos, nesse ponto, acredito que também tivemos nossa falha enquanto rede, nessa retirada.

\subsubsection{Elementos estruturantes: círculos, oficinas e aulas em movimento}

Procura-se pautar as ações pedagógicas pela apresentação de um conhecimento dinâmico, significativo ${ }^{118}$ e promotor do pensar dialético, tendo em vista a escassez de tempo, de conteúdos e o desafio adicional do enfrentamento do desânimo e da evasão dos alunos após experiências frustradas de ingresso no ensino superior, militando essencialmente para os que tiveram e continuam a ter espaços negados por uma estrutura racista, machista, homolesbobifóbica, transfóbica e elitista.

A estrutura didática abrange as disciplinas regulares: Linguagem e Códigos, Literatura, Redação, Inglês, Geografia, História, Filosofia, Sociologia, Atualidades, Matemática, Física, Química e Biologia, organizadas em cargas horárias proporcionais à sua incidência no Exame

\footnotetext{
${ }^{117}$ COSTA, M. Entrevista concedida a Stella Verzolla Tangerino. São Paulo, 16 fev. 2018.

118 Resume Ausubel: "[...] a essência do processo de aprendizagem significativa é que as idéias expressas, simbolicamente, são relacionadas às informações, previamente, adquiridas pelo aluno através de uma relação não arbitrária e substantiva". In: AUSUBEL, D. P.; NOVAK, J.; HANESIAN, H. Psicologia educacional. Rio de Janeiro: Editora Interamericana, 1980, p. 34.
} 
Nacional do Ensino Médio (ENEM) e nos principais vestibulares, conforme grade horária em anexo (Anexo 5).

Em acréscimo às aulas, a agenda do Cursinho envolve também atividades extracurriculares oferecidas todos os sábados: Orientação Pedagógica, Monitorias para reforço e saneamento de dúvidas, Círculos, Oficinas, um sistema de Tutoria e a "Aula em Movimento", animados pela certeza Freireana da significativa "importância de experiências informais nas ruas, nas praças, no trabalho, nas salas de aula das escolas, nos pátios dos recreios, em que variados gestos de alunos, de pessoal administrativo, de pessoal docente se cruzam cheios de significação". 119

E mais do que isso, como forma de resgatar e despertar outras inteligências e formas de expressão do pensamento, para além do estudo das disciplinas formais dos currículos;

Historicamente, os sistemas educacionais privilegiam os modos mais analíticos de aprendizagem, negando a importância das artes e das expressões culturais como formas válidas de conhecimento. No Ensino Médio, as aulas de artes visuais, por exemplo, seguindo as correntes educacionais positivistas, foram muitas vezes substituídas por aulas de desenho técnico ou de geometria com a justificativa de serem mais importantes já que atendem a demandas de preparação para o vestibular ou para o mercado de trabalho. As aulas de dança, de teatro e de música praticamente ficaram ausentes nos currículos das escolas brasileiras. (ênfase nossa) ${ }^{120}$

Os "Círculos" são debates de periodicidade semanal com cerca de uma hora de duração; neles são discutidos vários assuntos, quase sempre vinculados à opressão contra algum grupo, direta ou indiretamente. O diálogo, no contexto da Educação Popular, é sinônimo de educação, já que pressupõe reciprocidade e igualdade ${ }^{121}$, por isso, o momento do círculo é de grande relevância para a formação dos estudantes e também dos professores, não somente por abordar temas afetos aos vestibulares, mas, sobretudo, por auxiliar na construção de conceitos e conscientização relativa a questões como o feminismo, movimento afroindígena, movimento LGBTT, entre outros pouco trabalhados pelos currículos dos espaços formais de educação e das escolas das quais são egressos. ${ }^{122}$ Bem assim, nas palavras de Freire: "Aqueles que falam

\footnotetext{
119 FREIRE, P. Pedagogia da autonomia: saberes necessários à pratica educativa. São Paulo: Paz e Terra, 1997, p. 50.

${ }^{120}$ VIANA, M. L. Estéticas, experiências e saberes: artes, culturas juvenis e o Ensino Médio, In: DAYRELL; CARRANO; LINHARES, Op. Cit., 2014, p. 252.

${ }^{121}$ BEISIEGEL, C. de R. Política e Educação Popular: a teoria e a prática de Paulo Freire no Brasil. Brasília: Liber, 2008.

${ }^{122}$ Destacamos que "Às questões de gênero, raça e etnia (herdadas dos anos 1970 e 1980), mais recentemente se somaram demandas voltadas às distintas orientações sexuais e aos "jovens com
} 
de modo democrático precisam silenciar-se para que se permita que a voz daqueles que devem ser ouvidos emerja". ${ }^{123}$

A propósito,

O diálogo é o encontro entre os homens, mediatizados pelo mundo, para designá-lo. Se, ao dizer suas palavras, ao chamar ao mundo, os homens o transformam, o diálogo impõe-como o caminho pelo qual os homens encontram seu significado enquanto homens, o diálogo é, pois, uma necessidade existencial. ${ }^{124}$

A esse tocante, o aluno Cleiton França Santos, 18 anos, relata-nos:

[...] o cursinho teve grande importância para sanar a ignorância política que é reproduzida e tão pouco importante no ensino médio. Conversar, debater e criar perspectivas para o futuro são um dos fatores que o ensino público deveria oferecer, mas isso não ocorre diferentemente do cursinho. Recebemos suporte para analisarmos tudo aquilo que é apregoado rumo a alienação, ou seja, os professores durante as aulas nos fazem pensar e refletir sobre a nossa realidade, e questiona-la de forma autônoma. De fato, a grande importância pra mim no cursinho, em específico o Florestan Fernandes, foi a ajuda na minha identidade e reconhecimento como AFRO-INDÍGENA; reconhecimento que me toca profundamente, seja na alma, na carne ou até mesmo no coração; reconhecimento que mudou minha perspectiva de olhar o mundo, reconhecimento que me ajudou a me engajar mais e mais na luta negra e indígena. E por fim, seu objetivo com agente transformado está sendo efetivo, principalmente por levar educação pública de qualidade. ${ }^{125}$

Incontestável a proximidade com os "Círculos de Cultura" 126 freireanos, espaços educativos para diálogo e construção. Marinho explica-nos um pouco de sua dinâmica:

Círculo de Cultura era uma ideia que substituía, naquele processo de alfabetização, a sala de aula. Tinha a nomenclatura de Círculo porque todos seus participantes formavam a figura geométrica do círculo, nessa disposição todos se olhavam e se viam. Cultura porque havia uma interação das relações

deficiência", configurando-se, assim, um dinâmico mapa da diversidade da juventude brasileira". In: NOVAES, R. As juventudes e luta por direitos. Le Monde Diplomatique, n. 64, 5 nov. 2012. Disponível em $<$ http://diplomatique.org.br/as-juventudes-e-a-luta-por-direitos/>. Acesso em 23 mar. 2017.

${ }^{123}$ FREIRE, P. Pedagogia dos sonhos possiveis. São Paulo: Paz e Terra, 2014, p. 90.

${ }^{124}$ FREIRE, P. Conscientização: teoria e pratica da libertação: uma introdução ao pensamento de Paulo Freire. $4^{\text {a }}$ ed. São Paulo: Moraes, 1980, p. 82.

${ }^{125}$ FRANÇA, C. Entrevista concedida a Stella Verzolla Tangerino. São Paulo, 16 jun. 2017.

${ }^{126}$ Nas palavras do próprio idealizador dessa dinâmica: “[...] Assim em lugar de escola, que nos parece um conceito, entre nós, demasiado, carregado de passividade, em face da nossa própria formação (mesmo quando lhe dá o atributo de ativa), contradizendo a dinâmica fase de transição, lançamos o Círculo de Cultura. Em lugar de professor, com tradições fortemente "doadoras", o Coordenador de Debates. Em lugar de aula discursiva, o diálogo. Em lugar de aluno, com tradições passivas, o participante de grupo. Em lugar dos "pontos" e de programa alienados, programação compacta, "reduzida", "codificada" em unidades de aprendizado". In: FREIRE, P. Educação como pratica da liberdade. $27^{\mathrm{a}}$ ed. São Paulo: Paz e Terra, 2003. Coleção Leitura, p. 111. 
do homem com a realidade, recriando-a e buscando-se a dinamização de seu espaço no mundo. ${ }^{127}$

Para Freire, o Círculo de Cultura seria o ambiente nos quais se

[...] re-vive a vida em profundidade crítica. A consciência emerge do mundo vivido, objetiva-o, problematiza-o, compreende como projeto humano. Em diálogo circular, intersubjetivando-se mais e mais, vai assumindo criticamente, o dinamismo de sua subjetividade criadora. Todos juntos, em círculo, e em colaboração, re-elaboram o mundo [...]. ${ }^{128}$

O "Sistema de Tutoria" envolve a escolha pelo aluno, de um professor para seu acompanhamento por meio de uma lista circulada no início do período letivo. O tutor fica responsável por estabelecer um contato mais aproximado com o tutorando, seguindo sua frequência de perto, assistindo à suas dificuldades individuais (problemas financeiros para frequentar o Cursinho, emprego, questões familiares ou de saúde) ou escolares de modo a tornar mais confortável sua experiência no Cursinho.

As “Oficinas” são pensadas de modo a conjugar pausas necessárias na jornada de estudo a experiências artísticas de caráter mais prático. Cabe ressaltar que "o corpo para o jovem funciona como um vetor de agregação e de experiência estética coletiva, representado pela forma como exprimem as sensações e sensibilidades vividas em comum". ${ }^{29}$

Desde março de 2013, data do ingresso da autora no Cursinho, algumas das oficinas oferecidas no Florestan foram: grafite, stencil, criação literária, capoeira, violão, Hip Hop ${ }^{130}$, língua alemã, exibição do curta metragem "Racionais", atuação das mulheres no Hip Hop com Domênica Dias. Os materiais para as oficinas são financiados com recursos restritos egressos de doações e campanhas de arrecadação promovidas pelo próprio Cursinho.

É pertinente a citação que se segue:

[...] educação popular vivenciada nos movimentos sociais proporciona processos educativos e de produção de saberes entre pessoas que comungam de objetivos e identidades comuns, mediados por práticas organizativas e

\footnotetext{
${ }^{127}$ MARINHO, A. R. B. Círculo de cultura: origem histórica e perspectivas epistemológicas. São Paulo, 2014. Dissertação (Mestrado em Educação) - Faculdade de Educação, Universidade de São Paulo, p. 50.

${ }^{128}$ FREIRE, P. Pedagogia do oprimido. $17^{\mathrm{a}}$ ed. Rio de Janeiro: Paz e Terra, 1987, p. 17.

${ }^{129}$ VIANA, M. L., Estéticas, experiências e saberes: artes, culturas juvenis e o Ensino Médio. In: DAYRELL; CARRANO; LINHARES, Op. Cit., 2014, p. 256.

130 "O papel do Hip Hop em São Paulo nos últimos 30 anos foi justamente de ser a "liga" que, num primeiro momento, construiu uma estética autóctone, a periférica, que possibilitou a elaboração de um discurso performático de pertencimento à periferia", cf. MACEDO, M. Hip-Hop SP: transformações entre uma cultura de rua, negra e periférica (1983-2013). In: KOWARICK; FRÚGOLI JR., Op. Cit., 2016, p. 49.
} 
discursivas em que todos são sujeitos do processo. As variadas formas e linguagens utilizadas como a música, o teatro, a mística, os símbolos, os textos escritos, a linguagem oral e todos os recursos utilizados formam uma rica contribuição para as concepções de educação. ${ }^{131}$ (ênfase nossa)

A “Aula em Movimento", à exemplo da “Aula-oficina” de que relata-nos Barca ${ }^{132}$, é uma atividade de periodicidade anual, pensada de maneira interdisciplinar, proferida em conjunto pelos professores ao pé dos diversos marcos históricos do centro da cidade de São Paulo: o Theatro Municipal como tema para a Semana de Arte Moderna, o Viaduto do Chá como palco para discussão da urbanização e migração, debate sobre as primeiras escolas jesuítas no Pátio do Colégio, entre outros temas, promovendo além da vivência do conteúdo, a vivência de "estar no centro" da cidade, um espaço privilegiado, por vezes inacessível ${ }^{133}$, atualizando a lição de Milton Santos de que "a proximidade é potencializadora da criação de laços culturais e de identidade". ${ }^{134}$

Com tais recursos, busca-se suavizar a distância muitas vezes assimétrica entre a prática e os conteúdos, motivando e colocando o estudante como protagonista no processo de aprendizagem, permitindo interdisciplinaridade e conexões entre contextos variados, em oposição aos currículos essencialmente conteúdistas dos cursinhos pré-vestibular do mercado e até das escolas das quais saíram. Um trabalho de construção, de ancoragem nos conceitos préexistentes no estudante a fim de despertar-lhe a curiosidade e a vontade de abrir-se para o assunto que se quer ensinar.

Isso porque, ilumina-nos Isabel Barca:

A aprendizagem processa-se em contextos concretos. É necessário que os conceitos façam sentido para quem os vai aprender. Existe uma multiplicidade de factores da cognição a ter em conta. As vivências prévias dos sujeitos e a natureza específica do conhecimento, o tipo de tarefas a desempenhar, as aptidões individuais são aspectos fundamentais para a progressão do conhecimento. ${ }^{135}$

No mesmo sentido, as palavras de Maria Auxiliadora Schmidt,

\footnotetext{
${ }^{131}$ BATISTA, Op. Cit., 2005, p. 11.

${ }^{132}$ BARCA, I. Educação Histórica: uma nova área de investigação. Revista da Faculdade de Letras História, Porto, v. 2, n. 3, 2001.

${ }^{133}$ Interessantíssima é a análise de Caldeira: “[...] A circulação no espaço público sempre foi regulada. Desde os tempos de Baudeleire, vagar pela cidade foi mais para uns - homens, ricos, dândis - do que outros - mulheres, pobres, negros, jovens. In: CALDEIRA, T. P. R. Qual a novidade dos rolezinhos? Espaço público, desigualdade e mudança em São Paulo. Novos Estudos - Cebrap, São Paulo, v. 22, n. 98, 2014, p. 13.

${ }^{134}$ SANTOS, M. A força do lugar: In: A natureza do espaço. $4^{\text {a }}$ ed. São Paulo: Edusp, 2006, p. 216.

${ }^{135}$ BARCA, Op. Cit., 2001, p. 21.
} 
É necessário, também, destacar que, do ponto de vista didático-pedagógico, só é relevante a aprendizagem que seja significativa para o próprio aluno. Tal fato pressupõe o trabalho com o conhecimento histórico em sala de aula particularmente em duas direções: na primeira, o conteúdo precisa ser desenvolvido na perspectiva de sua relação com a cultura experiencial dos alunos e com suas representações já construídas; na segunda, para uma aprendizagem significativa, é necessário construir, em sala de aula, um ambiente de compartilhamento de saberes. ${ }^{136}$

Destaca-se também o Coletivo Conceição Evaristo $^{137}$, organizado em 2014 pelas professoras do cursinho com o intuito de construir um espaço auto-organizado de mulheres, que inclua professoras e alunas, a fim de conseguir empoderar umas às outras e fortalecer a luta contra o machismo e participação enquanto mulheres militantes, e conseguir pensar em conjunto soluções e prevenções para eventuais casos. Trata-se de uma dimensão ética, política e prática do feminismo. Desde sua criação, tornou-se um espaço no qual as alunas podem contar com apoio frente alguma situação de gênero que ocorra no âmbito do Cursinho ou queiram orientação para o enfrentamento de alguma questão fora daquele ambiente. Viu-se que a existência desses coletivos colabora para a união entre estudantes e cria um laço que pode ser essencial em vários aspectos, haja vista o incentivo a essas iniciativas ter contribuído expressivamente na conscientização e empoderamento das alunas.

\subsection{Carta de princípios e I Congresso de Educação Popular Florestan Fernandes}

Por ocasião da ruptura da unidade com a Rede Emancipa de Cursinhos Populares, em abril de 2016, pensou-se em um evento que configurasse sua autonomia e no qual pudesse ser redigida, conjuntamente com os alunos, uma Carta de Princípios do novo Cursinho.

O I Congresso de Educação Popular Florestan Fernandes, ocorrido em 23 de julho de 2016, na Universidade de São Paulo - USP versou sobre a relevância e o significado do Cursinho para os alunos que participaram do evento e mostrou-se a ocasião para essa empreitada.

Foram convidados para a Mesa de Abertura, no período da manhã, intitulada "Educação Popular: Resistência" a assessora do programa EJA da Ação Educativa, Ednéia Gonçalves, Emerson Gabriel dos Santos, integrante da Frente de Cursinhos Populares de São Paulo e professora do cursinho Griot, Jupiara Castro, do Núcleo de Consciência Negra e o Professor

\footnotetext{
${ }^{136}$ SCHMIDT, M. A. A formação do professor de história. In: BITTENCOURT, C. (Org.). O saber histórico na sala de aula. São Paulo: Contexto, 1998, p. 18.

${ }^{137}$ O Coletivo homenageia Conceição Evaristo, uma das mais notáveis escritoras negras, expoente da literatura brasileira e afro-brasileira da atualidade. Sua literatura traz significativas reflexões sobre a problemática de raça e gênero e sobre desigualdade social.
} 
Elie George Guimaraes Ghanem Junior, professor de Sociologia da Educação na Faculdade de Educação da Universidade de São Paulo (FE-USP).

Durante a tarde, na Mesa (Gestão Democrática e Cursinho Populares) convidamos os ex-alunos Thiago da Silva, Yago Duarte, Jacquelyn da Silva Souza e Eduarda Ribeiro Rodrigues, atualmente professores do Cursinho para relatarem suas experiências após o ingresso no ensino superior, narrativas que muito impressionaram os alunos participantes, justamente porque materializavam que o sonho do ingresso na Faculdade não era uma abstração inalcançável.

Ao final do dia, foram estruturados na Carta, os objetivos gerais do Cursinho, sumarizados em três eixos: Política Externa; Política Interna e Princípios. O primeiro estipulava o mapeamento dos espaços culturais e escolas próximos à USP; das escolas e moradias dos alunos, dos grêmios estudantis dessas escolas, dos espaços culturais próximos ao CPFF e dos alunos visando a aproximação entre escola e Cursinho, tendo como desdobramento natural a formação de grupos de alunos articuladores. Foi também pensada para esse eixo, a intenção de fortalecimentos dos coletivos do CPFF para atividades fora do Cursinho; e encontros periódicos com alunos de outros Cursinhos populares.

No âmbito da Política Interna, estruturou-se como linhas gerais a agenda de assembleias bimestrais entre alunos e professores, e entre alunos somente; reuniões de professores abertas e divulgadas para os alunos; articulação e autonomia das disciplinas; Encontros de Formação de professores bianuais, com balanço sobre permanência e experiência no CPFF; oferecimento de Orientação pedagógica para os alunos, aproximação de professores e alunos, organização da Feira de Profissões e tour pela USP, apresentando os cursos e opções de carreiras, transversalização dos temas dos círculos nas disciplinas regulares, criando assim uma conexão entre o que foi debatido e o conteúdo cobrado pelos exames e pela redação, à medida do possível.

Como Princípios, os alunos e professores levantaram grandes temas que consideravam como essenciais a ser elencados como bandeiras de luta do Cursinho: combate ao machismo, racismo, lesbofobia, transfobia, homofobia, contra o Processo de Destituição da Presidenta Dilma Roussef em 2016, contra a Escola sem Partido e Contra o vestibular, nos moldes como é estruturado atualmente. Tais temas são o exemplo concreto de que o Movimento dos Cursos Pré-Vestibulares Populares, mais do que surgir em cena como um novo ator coletivo, é "um sujeito social político, pois que se movimentando com a intencionalidade de abrir espaços a 
negros e pobres para o acesso destes ao ensino superior, resiste a formas e práticas naturalizadas na sociedade (racismos, discriminações, desigualdades, mérito como merecimento, etc)". ${ }^{138}$

A realização desse Congresso impactou positivamente, sobretudo na construção do material para os Círculos de debates do ano subsequente (2017).

\subsection{Perfil docente}

[...] A paixão raramente se afirma institucionalmente. Espera-se que os professores publiquem trabalhos cientificos, mas ninguém espera ou exige deles que realmente se dediquem ao ensino de um modo apaixonado que varia de pessoa para pessoa. Os professores que amam os alunos e são amados por eles ainda são "suspeitos" na academia. Parte dessa suspeita se deve à ideia de que a presença de sentimentos, de paixões, pode impedir a consideração objetiva dos méritos de cada aluno. Mas essa noção de baseia no pressuposto falso de que a educação é neutra, de que existe um terreno emocional "plano" no qual podemos nos situar para tratar a todos de maneira igualmente desapaixonada.

Bell Hooks ${ }^{139}$

[...] Sou adjetivamente pedagogo, porque, substantivamente, sou político.

Paulo Freire em entrevista a Carlos Nuñez ${ }^{140}$

Para Gutiérrez ${ }^{141}$, o educador popular tem um papel eminentemente político ${ }^{142}$, devendo tomar partido frente à ressignificação da realidade social ${ }^{143}$, trabalho que é antes de tudo "paixão indignada e cheia de ternura que incorpora a vontade individual à teoria, à ciência e à criatividade. É uma paixão assumida e recriada por militantes que se entregam pelo projeto de

\footnotetext{
${ }^{138}$ NASCIMENTO, Op. Cit., 2012, p. 94.

${ }^{139}$ HOOKS, B. Ensinando a transgredir: a educação como pratica da liberdade. Trad. Marcelo Brandão Cipolla. São Paulo: Editora WMF Martins Fontes, 2013, p. 223.

${ }^{140}$ NÚÑEZ-HURTADO, C. Vigencia del pensamiento de Paulo Freire. Revista Educación de adultos y desarrollo, México, n. 69, 2007, p. 9.

${ }^{141}$ GUTIÉRREZ, F. Educação como práxis política. São Paulo: Summus, 1988.

142 "O poder do professor está tanto na sua capacidade de refletir criticamente sobre a realidade para transformá-la quanto na possibilidade de formar um grupo de companheiros e companheiras para lutar por uma causa comum". In: GADOTTI, Op. Cit., 2003, p. 110.

143 " [...] O educador ou educadora como um intelectual tem que intervir. Não pode ser um mero facilitador. [...] O que o educador deve fazer quando ensina é possibilitar os alunos a se tornarem eles mesmos. E ao fazer isso, ele ou ela vive a experiência de relacionar democraticamente como autoridade com a liberdade dos alunos", cf. RICCI, R. A complexa relação entre educação e movimentos sociais no Brasil ou Aventuras e Desventuras da Educação Popular em tempos difíceis. In: INSTITUTO SUPERIOR DE EDUCAÇÃO ANÍSIO TEIXEIRA/FUNDAÇÃO HELENA ANTIPOFF. Escritos em Educação. Belo Horizonte: Ibirité, 2004, p. 4.
} 
vida solidária, fraterna e livre" ${ }^{144}$. O Cursinho Florestan nos deu de forma generosa essa vivência.

A historiadora Lilian L'Abbate Kelian, prefaciando A Educação Democrática diz-nos que o desafio da promoção da Educação emancipadora surge simultaneamente a um receio de que talvez esse desejo não possa ser concretizado ${ }^{145}$, tamanha a consistência de um trabalho que passa não somente pela ansiedade de ensinar, mas também pela consciência de ter que dar espaço para esse conhecimento se realizar, de contornar o medo, o desânimo, a frustração dos alunos, a falta de tempo, de espaço, de apoio, de aporte financeiro para realizar muitas das atividades idealizadas, de obter o compromisso e a permanência dos professores sábado após sábado.

Mais do que em qualquer outro espaço de educação, o professor do Cursinho Popular deve além dos conteúdos formais, prover aos alunos "as condições que irão encoraja-los a aventurar-se para fora do "quadrado", começando um processo de busca pelas áreas de força em que poderão aperfeiçoar sua confiança em suas próprias habilidades". ${ }^{146}$

A professora de linguagens e códigos, Fabiana $\mathrm{Cabral}^{147}$, em entrevista a nós concedida, ressalta justamente essa contradição expressa por Kelian,

de se buscar uma educação libertadora, que escape à lógica objetivista e mercantilista do sistema em que vivemos, mas ao mesmo tempo precisar suprir a necessidade que esse mesmo sistema impõe à educação. Queremos fazer educação popular, mas ao mesmo tempo queremos que nossos estudantes consigam acessar a Universidade Pública, ou seja, passar numa seleção que defendemos que não deveria existir.

A propósito,

É notório que o trabalho dos cursos pré-vestibulares populares possui, além da dimensão explicita que é o ensino preparatório para o vestibular, outra dimensão especificamente política, que coloca em questão o ensino superior e exige políticas concretas no sentido da abertura das instituições deste nível de ensino a estudantes "negros e carentes". Fazem parte da própria natureza desses cursos um desejo e uma exigência: o desejo de participar dos processos de difusão e produção dos conhecimentos codificados em face das transformações do trabalho e a exigência de mudanças no estatuto do ensino superior e nas formas de funcionamento das instituições universitárias. ${ }^{148}$

\footnotetext{
${ }^{144}$ PELOSO, R. (org.). Trabalho de base. São Paulo: Expressão Popular, 2012, p. 10.

${ }^{145}$ KELIAN, L. L. Prefácio. In: HECHT, Y. Educação democrática: o começo de uma história. Trad. Adriana Scandolara. Belo Horizonte: Autêntica, 2016, p. 9.

${ }^{146}$ HECHT, Op. Cit., 2016, p. 81.

${ }^{147}$ CABRAL, F. S. Entrevista concedida a Stella Verzolla Tangerino. São Paulo, 21 fev. 2017.

${ }^{148}$ NASCIMENTO, Op. Cit., 2012, p. 22.
} 
O educador de um Cursinho Popular precisa considerar o desafio adicional de conceber uma aula de tal modo instigante que possa assegurar a continuidade da presença do estudante, uma vez que a evasão dos alunos é um problema recorrente. Em um paralelo bastante interessante com relato de Daniel Pennac, assemelha-se ao trabalho de "mergulhar de cabeça" até conseguir "resgatar" o aluno. ${ }^{149}$

[...] Às vezes, no final do ano, os cursos têm mais professores do que alunos! Este fenômeno, com picos normalmente em maio (quando diversos cursos realizam seus primeiros exames simulados e agosto/setembro (época de inscrição nos vestibulares), está relacionado à fragilidade do acesso à universidade enquanto projeto de vida para indivíduos de grupos sociais desfavorecidos, entre os quais o ingresso na universidade é exceção, e não regra. Diante das adversidades e da tensão, por força dos outros projetos (o ingresso no mercado de trabalho, com vistas a contribuir para a renda familiar é o predominante), e da pressão social negativa, baseada na ideologia do fracasso escolar (atribuído à incapacidade do aluno e as suas condições adversas, e que são alçados ao status de barreiras intransponíveis), a desistência e a evasão são realidades massivas em quase todos os cursos prévestibulares populares. ${ }^{150}$

Mendes faz aguda análise sobre a formação dos professores desses coletivos, mostrando-nos que:

[...] Dentre os formados, a maior a parte não tem licenciatura, não é professor por formação e falta-lhes uma compreensão técnica e teórica da Pedagogia. Todavia, se por um lado as adversidades acima causam a evasão de uma parcela significativa dos alunos dos núcleos, por outro fazem acontecer um fenômeno educacional que poderíamos descrever como pedagogia intuitiva. Essa pedagogia está fundada em uma identidade cultural entre educador e educando, que por terem na maioria das vezes a mesma origem histórico-social, sofrerem ou terem sofrido as mesmas agruras, possuem cosmovisões bastante sintonizadas, o que cria um elo dialógico comunicativo, fundamentalmente necessário para o processo de aprendizagem. Acrescente-se o fato de haver ainda uma sintonia étnicocultural entre educador e educando. (ênfase nossa) ${ }^{151}$

\footnotetext{
149 "Os professores que me salvaram - e que fizeram de mim um professor - não tinham recebido nenhuma formação para esse fim. Não se preocuparam com as origens da minha incapacidade escolar. Não perderam tempo a procurar as causas nem tampouco a ralhar comigo. Eram adultos confrontados com adolescentes em perigo. Pensaram que era urgente. Mergulharam de cabeça. Não me apanharam. Mergulharam de novo, dia após dia, mais e mais... Acabaram por me pescar. E muitos outros como eu. Repescaram-nos, literalmente. Devemos-lhes a vida". In: PENNAC, D. Diário de escola. Rio de Janeiro: Rocco, 2008, p. 47.

150 SANTOS, R. E. Pré-vestibulares populares: dilemas políticos e desafios pedagógicos. In: CARVALHO; ALVIM FILHO; COSTA, Op. Cit., 2008, p. 199.

${ }_{151}$ MENDES, F. L. S. Didática, formação docente e supervisão pedagógica nos CPVCs. In: CARVALHO; ALVIM FILHO; COSTA, Op. Cit., 2008, p. 66.
} 
No caso em estudo, o cenário é heterogêneo; alguns de nossos professores ainda não concluíram os cursos de bacharelado, não tendo concluído, portanto, o período da licenciatura. Outros, tendo finalizado seus cursos, estão já na pós-graduação lato ou stricto sensu, na área da Educação ou nos campos de seus próprios cursos de origem.

O processo exige persistência e unidade de seus militantes para a construção dessa “Educação Menor", pensada por Sílvio Gallo:

[...] professor seria aquele que procura viver a miséria do mundo, e procura viver a miséria de seus alunos, seja ela qual miséria for, porque necessariamente miséria não é apenas uma miséria econômica: temos miséria social, temos miséria cultural, temos miséria ética, miséria de valores. Mesmo em situações em que os alunos não são nem um pouco miseráveis do ponto de vista econômico, certamente eles experimentam uma série de misérias outras. O professor militante seria aquele que, vivendo com os alunos o nivel de miséria que esses alunos vivem, poderia, de dentro desse nível de miséria, de dentro dessas possibilidades, buscar construir coletivamente. ${ }^{152}$ (ênfase nossa)

Do ponto de vista institucional, são organizadas reuniões quinzenais para delinear questões didáticas, políticas e burocráticas referentes a rotina Cursinho e aprofundar questões pedagógicas. As datas e locais dessas reuniões são decididas em conjunto e informadas através de um grupo de e-mail dedicado aos professores. É também enviado pela Coordenação, responsável pela integração dos professores, um e-mail semanal de informes com a grade horária do próximo sábado e questões mais urgentes a serem resolvidas. Os alunos recebem a grade normalmente às sextas-feiras a noite, através de postagem no grupo do Cursinho na rede social Facebook

Pouco antes do início de cada semestre letivo é ministrado um dia de "Formação de Professores", entendido como uma reunião dinâmica na qual são debatidos casos hipotéticos ou realmente vividos em sala de aula e qual seria, dentro da filosofia do Cursinho, a melhor condução para eles. "Apesar do reconhecimento de que a luta se aprende lutando, há unanimidade de que é necessário formação e consciência política de todos" ${ }^{153}$, daí a grande importância de tais encontros, sobretudo para que os novos professores se familiarizem com a orientação ideológica e política do Cursinho.

\footnotetext{
${ }^{152}$ GALLO, Op. Cit., 2002, p. 171.

${ }^{153}$ KOHARA, L. A exploração nos cortiços do Centro e a luta pelo direito de morar dignamente. In: KOWARICK; FRÚGOLI JR., Op. Cit., 2016, p. 156.
} 
À época da gestão da unidade Florestan pela Rede Emancipa, eram distribuídos no início dos semestres, os Manuais do Aluno (Anexo 6) e do Professor (Anexo 7). Atualmente, entregase aos alunos apenas o Cronograma das disciplinas com os conteúdos que serão abordados, para maior organização dos alunos (Anexo 8).

A questão do cronograma unificado, exigência da coordenação para que em caso de ausência de um dos professores daquela área outro consiga substitui-lo sem prejuízo da continuidade da matéria, é um ponto bastante problemático e no qual divergimos da coordenação justamente por acreditar que o prejuízo advindo desse enrijecimento da autonomia e criatividade das ações educacionais do professor acaba sendo maior do que o suposto benefício de uma organização do conteúdo. Esse direcionamento normativo, quase uma antítese do que se defende no Cursinho, fomenta, acreditamos, uma produção de conhecimento anacrônico e muitas vezes desvinculado da vivência do estudante.

Esclarece-nos Sposito:

A experiência desses movimentos revela, em toda sua trajetória, que há um saber que se recria e se transforma no desenvolvimento e no amadurecimento das lutas por educação. A luta social educa. O modo como são conduzidas todas as etapas, seus erros e acertos, geram uma nova pedagogia que impõe aos movimentos, de forma cada vez mais profunda, a necessidade do confronto dessa prática com a educação que se recebe na escola. A possibilidade de discutir a condição de classe, a experiência de participação democrática, a luta cotidiana contra relações humanas desiguais, a descoberta do outro como companheiro de caminhada, o respeito ao seu modo de ser e a experiência compartilhada ensinam muito. Ensinam a descobrir um modo diverso de conceber o existir, o educar, o saber. Estes são os germes de uma nova concepção educativa que nega, em profundidade, a prática dominante nas escolas, que discrimina os trabalhadores, os pobres e os marginalizados. A luta pela educação também ensina a criticar a escola conduzindo à negação dela na forma em que existe hoje. ${ }^{154}$

Das entrevistas conduzidas com treze professores do Florestan Fernandes, identificamos cinco eixos de análise que nortearão a compreensão do universo do Cursinho, pela ótica docente: 1) A chegada (motivação inicial); 2) O diferencial da Educação Popular na visão docente, 3) A visão do professor de Educação; 4) Contribuição pessoal e profissional da vivência do Cursinho e 5) Um fato marcante em sua trajetória docente no Florestan.

Com relação à primeira categoria, a motivação inicial para a procura de um cursinho popular é na totalidade dos casos a busca por um projeto que unisse a formação profissional em

${ }^{154}$ SPÓSITO, M. P. Luta popular por educação: projeto de uma nova escola. Caderno do Cedi, São Paulo, n. 15, 1986, p. 59. 
curso a ideais políticos e pessoais. A forma de ingresso mais comum é o convite de algum amigo que já conhecia os trabalhos e leva o futuro educador a envolver-se ou então através da internet, geralmente das redes sociais, nas quais são divulgadas as aulas e eventos do Cursinho.

A professora de espanhol Talita Zanata ${ }^{155}, 27$ anos, que ingressou em agosto de 2014 no Florestan, conta-nos que após voltar de um intercambio para a Argentina e participando lá de um projeto voluntário de complementação da educação, em áreas periféricas, teve vontade de procurar algo análogo quando voltou ao Brasil:

Fiz intercambio em 2014 para a Argentina e em um curso de educação popular e gênero que assisti lá conheci o conceito de Educação Bairro, que é um modo de complementar a educação. Comecei a frequentar essas atividades. Quando cheguei ao Brasil tentei encontrar algo parecido e uma coisa levou a outra e cheguei ao Florestan.

Para a professora Regina França Ferreira, 53 anos, a motivação foi a possibilidade de ensinar Matemática aos alunos que não tinham condições de que pagar por um cursinho prévestibular comercial.

Fabiana Cabral Silva, professora de português, $25 \operatorname{anos}^{156}$, conta-nos o que a levou procurar uma estrutura de educação não-formal:

Sempre acreditei que o sistema educacional adotado na maior parte do Brasil não levava em conta as particularidades do sujeito educando. Com bastante afeição pela educação freiriana, com a qual tive mais contato no início, e por acreditar que a educação é um espaço de formação muito mais pessoal que profissional, procurei lugares que tivessem como fundamento políticopedagógico um método de educação que realmente valorizasse a experiência do aluno fora do ambiente escolar. Para mim, a educação tinha que fugir à lógica capitalista de formar apenas para serem mão de obra.

Com relação ao diferencial da educação não formal, os entrevistados consideraram como nota mais marcante a liberdade de trabalhar diferentes conteúdos, sem seguir algo préformatado ou imposto ${ }^{157}$, em que pese o objetivo da aprovação no vestibular, ressaltando como

\footnotetext{
${ }^{155}$ ZANATA, T. A. Entrevista concedida a Stella Verzolla Tangerino. São Paulo, 17 jul. 2017.

${ }^{156}$ CABRAL, F. S. Entrevista concedida a Stella Verzolla Tangerino. São Paulo, 21 fev. 2018.

${ }^{157}$ A esse respeito, veja-se: "A educação não-formal, ao contrário da educação formal, caracteriza-se por não ter a preocupação de desenvolver um currículo predefinido, um currículo que se faz principalmente baseado em desejos, necessidades e interesses das pessoas que constituem os grupos envolvidos em ações e práticas desse campo educacional”. In: FERNANDES, R. S. A cultura e transformação no contexto da educação não formal. Regulamento do Programa Rumos - Educação Cultura e Arte. São Paulo: Itaú Cultural, 2005. Documento disponível em $<$ www.itaucultural.org.br/rumos>. Acesso em 18 abr. 2018.
} 
ponto extremamente positivo essa autonomia no ensinar ${ }^{158}$, rompendo com a mera reprodução das práticas da educação regular.

Graziela Campana Drago ${ }^{159}$, professora de redação, 25 anos pondera: “A educação não formal permite associações interdisciplinares nem sempre contempladas nas instituições formais, já que é frequente que a prioridade dessas organizações seja cumprir um cronograma de conteúdos".

A possibilidade de realizar projetos diferenciados, estimular o pensamento crítico, nas palavras da professora de espanhol Alessandra de Assis ${ }^{160}, 25$ anos, "mostrar como o próprio conteúdo que eles estudam é na verdade algo escolhido" é uníssona nas entrevistas. A professora Talita Zanata reforça: “Os alunos só param de aprender, porque ficam bloqueados. Tento trazer importância para o aluno, o ensino regular fala muito em autonomia, mas não traz essa autonomia. A educação não formal consegue fazer isso melhor".

O professor de inglês, João Prado ${ }^{161}$, 46 anos, conta-nos que é justamente essa possibilidade criativa que traz o diferencial dos Cursinhos populares:

E aí entra os cursinhos populares que são uma excelente oportunidade de criar uma forma de difusão de conteúdos com os próprios alunos, conforme suas especialidades. Nesse ponto, tem duas experiências que vivi... a primeira foi a do meu pai que criou a coleção primeiros passos que foi o canal não só para incentivo à leitura como para a formação de escritores. E a segunda do pai de mais um grande amigo que na década de 70 e 80 estava na Editora Abril criando as enciclopédias Conhecer. Me lembro como se fosse ontem do Professor Ottaviano De Fiore comentando de que naquela época as famílias já se preocupavam com a deterioração do ensino público e pais compravam as enciclopédias e liam com os filhos.

O professor de matemática Caio Jonas Vieira da Silva ${ }^{162}$, de 22 anos, considera que o grande diferencial do Cursinho é "dar voz às minorias" e "fazer do local de aulas um ambiente acolhedor." Bastante interessante é fala do Professor de artes, Marcelo Augusto Boujikian ${ }^{163}$, 28 anos:

Na educação popular, existe espaço para uma atividade de descontração, como uma oficina que movimente o corpo ou traga um conhecimento de um escopo

\footnotetext{
${ }^{158}$ Anota Chauí: "[...] a autonomia redefine o sentido da representação e da participação". In: CHAUÍ, M. Brasil: mito fundador e sociedade autoritária. São Paulo: Fundação Perseu Abramo, 2000, p. 304.

${ }^{159}$ DRAGO, G. C. Entrevista concedida a Stella Verzolla Tangerino. São Paulo, 23 agosto. 2017.

${ }^{160}$ ASSIS, A. B. Entrevista concedida a Stella Verzolla Tangerino. São Paulo, 17 jul. 2017.

${ }^{161}$ PRADO, J. Entrevista concedida a Stella Verzolla Tangerino. São Paulo, 12 maio. 2018.

${ }^{162}$ DA SILVA, C. J. V. Entrevista concedida a Stella Verzolla Tangerino. São Paulo, 7 jul. 2017.

${ }^{163}$ BOUJIKIAN, M. A. Entrevista concedida a Stella Verzolla Tangerino. São Paulo, 6 jul. 2017.
} 
diferente, ou uma celebração conjunta, isso deixa a mente em estado mais relaxado e permite que se recupere para se concentrar posteriormente.

\section{A professora Fabiana Cabral destaca que}

[...] o diferencial se encontra justamente na valorização da realidade do estudante, ou seja, trazendo para a sala de aula o que ele já conhece e traz como bagagem. É a tal história, por exemplo, de que não se ensina português a um falante nativo de português, mas constrói, junto a ele, as diversas maneiras com as quais ele pode brincar com seu idioma. Não sei se faria diferente se estivesse dando aulas no ensino regular. Acredito que é muito mais difícil assumir essa postura dialógica, sobretudo em espaços privados, pois existe a cobrança de se estabelecer uma distância entre o papel do professor e o do aluno, o qual não penso existir de forma tão categórica. Contudo, não saberia afirmar se realmente faria diferente do que faço no CPFF. ${ }^{164}$

Victor Augustus Manfredini Vital Bessa, professor de História, 24 anos, está no Florestan desde 2013 e pontua o necessário diálogo com a educação formal, em que pese a liberdade de conteúdos proporcionada pelo Cursinho:

Isso se faz necessário não só pelo conteúdo do vestibular, como também pela nossa estrutura de aula. O que vejo de diferente, da minha vivência da educação formal, são os espaços de protagonismo estudantil. Tanto o círculo, quanto o coletivo LGBT são exemplos de lugares onde os estudantes trocam experiências e vivências que ajudam a uma formação individual argumentativa e emancipadora. Ser um espaço não formal ajuda à defesa desses espaços, por haver menos interesses envolvidos e exigências, mas não é condição deles existirem, logo considero que tentaria levar a prática pedagógica do cursinho para a estrutura regular quando fizer parte dela. ${ }^{165}$

Para Victor, "todo compartilhamento de vivência e experiência com a intenção de emancipar é um ato de educar. É uma definição estrita, no sentindo de determinar intenção, mas também acho importante a amplitude do que é esse compartilhamento para não minimizar formas de conhecimento não hegemônicas".

O terceiro indicador, o das impressões dos docentes sobre o significado do educar, traznos que, em essência, o professor do Cursinho Florestan Fernandes entende o educar como uma construção conjunta, levando-se em consideração a bagagem que o aluno já traz consigo, como vemos na fala da professora Fabiana:

Tenho para mim que, antes de mais nada, não existe alguém na posição apenas de "educador", pois isto exigiria do outro exercer a função apenas de "educando". Como não acredito que exista educação sem aprendizado,

${ }^{164}$ CABRAL, F. S. Entrevista concedida a Stella Verzolla Tangerino. São Paulo, 21 fev. 2018.

${ }^{165}$ VITAL, Victor Augustus. Entrevista concedida a Stella Verzolla Tangerino. São Paulo, 7 junho 2018. 
procuro entender o verbo "educar" numa via de mão dupla. Enquanto ensino, eu também estou aprendendo. Eu tenho conhecimentos que minha trajetória e formação me concederam e os quais posso passar para pessoas com trajetórias e formações diferentes, enquanto elas fazem o mesmo comigo. ${ }^{166}$

A professora Talita Zanata avalia: "Eu acho que tem a ver com dar caminhos possíveis para as pessoas tornarem quem elas são e com isso você também vai se tornando outra pessoa. [...] a educação para o trabalho não é quem você é"167. Para a professora Regina Guimarães, "educar é muito mais do que ensinar conteúdos. Acho que tem a ver com auxiliar o aluno a significar o que ele aprende, a dar um sentido ao que lhe é apresentado. Essa significação não é somente intelectual, mas é feita principalmente estimulando o lado afetivo do aluno". ${ }^{168}$

O professor Marcelo Boujikian entende que

[...] Os professores também são estudantes, e apenas o que os diferencia dos demais é a sua disposição de investigar o tema em questão a fundo, para ter condições de mediar o debate. O caminho do conhecimento é sempre recriado a cada aula, e o trabalho em conjunto envolve oportunidades de aprendizado que muitas vezes abrangem aspectos da comunicação e socialibilização, ultrapassando as fronteiras do tema estudado. ${ }^{169}$

Graziela Drago filosofa: "Educar é relembrar algo como se você não entendesse e juntamente refazer um significado válido" ${ }^{170}$.

A quarta categoria abrange as contribuições pessoais e profissionais do Florestan na vida do educador voluntário. Os depoimentos ressaltam a formação política, além da experiência docente.

A professora de espanhol Ana Beatriz Takematsu ${ }^{171}$ relata:

Foi com os projetos do cursinho que me reconheci enquanto educadora e confirmei meus ideais políticos e relacionados à educação. $\mathrm{O}$ aprendizado pessoal é enorme, pelo convívio com professores e alunos donos de tantas histórias improváveis.

\footnotetext{
${ }^{166}$ CABRAL, F. S. Entrevista concedida a Stella Verzolla Tangerino. São Paulo, 21 fev. 2017.

${ }^{167}$ ZANATA, T. A. Entrevista concedida a Stella Verzolla Tangerino. São Paulo, 7 jul. 2017.

${ }^{168}$ GUIMARÃES, R. Entrevista concedida a Stella Verzolla Tangerino. São Paulo, 3 jul. 2017.

${ }^{169}$ BOUJIKIAN, M. A. Entrevista concedida a Stella Verzolla Tangerino. São Paulo, 6 jul. 2017.

${ }^{170}$ DRAGO, G. C. Entrevista concedida a Stella Verzolla Tangerino. São Paulo, 23 agosto. 2017.

${ }^{171}$ TAKEMATSU, B. Entrevista concedida a Stella Verzolla Tangerino. São Paulo, 4 jul. 2017.
} 
A professora de literatura Lara Rocha Santos ${ }^{172}, 26$ anos, diz-nos que através do trabalho no cursinho "[...] compreendo melhor na prática o que seria educação popular, os papéis do movimento negro e feminista e o que eu realmente acredito ser a função da esquerda no Brasil”.

Para a professora Alessandra ${ }^{173}$, o Cursinho a faz "ver a educação com outros olhos". Talita Zanata complementa:

[...] Uma das coisas que mais gosto é de como as reuniões com professores mostram como estamos preocupados em educar, compartilhar. Aprendi o quanto educação é compartilhar, ouvir. Principalmente, ouvir. Na pessoal, eu não seria quem eu sou sem o Florestan, porque desde questões políticas, orientação sexual, enfim, entender a família...eu nunca imaginaria me ajudou. Você vê nos alunos e se reconhece ne? Valorizamos a individualidade, a expressão dela. ${ }^{174}$

O professor Marcelo resume a participação no Florestan como uma das experiências mais determinantes de sua vida:

Eu aprendi a dar aulas ali, aprendi a me comunicar com as pessoas de forma mais eficiente, incluindo aspectos como a dicção e propulsão da voz, e trabalhar como parte de uma equipe. Aprendi muito me preparando para dar aulas, participando das oficinas e dos círculos sobre temas os mais variados possíveis. Aprendi muito sobre a importância de ouvir e apoiar as vozes do feminismo, movimento negro e LGBT. Me aproximei desses universos através do cursinho e acredito que esses conhecimentos me propiciaram um amadurecimento pessoal muito importante. ${ }^{175}$

A professora de língua portuguesa, Raphaela da Costa Crispim $^{176}, 22$ anos fala-nos de outro viés de contribuição pessoal:

Ver os rostos dos alunos quando conseguem elevar suas notas me traz satisfação pessoal e profissional, assim como vê-los socializando entre si, trocando experiências e se ajudando. $\mathrm{O}$ ingresso numa universidade pública não é a realidade da camada pobre da população, que sempre estudou em escola pública. Dizer para essas pessoas que elas são capazes, e mais que isso, que vão desempenhar essa tarefa muito bem na universidade, me faz pensar que faz sentido ter me esforçado para entrar na universidade.

Fabiana chama atenção para o componente emocional, como catalisador não só do aprendizado, mas da fecundidade das relações sociais, em geral:

\footnotetext{
172 ROCHA, L. S. Entrevista concedida a Stella Verzolla Tangerino. São Paulo, 23 jun. 2017.

${ }^{173}$ ASSIS, A. B. Entrevista concedida a Stella Verzolla Tangerino. São Paulo, 17 jul. 2017.

${ }^{174}$ ZANATA, T. A. Entrevista concedida a Stella Verzolla Tangerino. São Paulo, 7 jul. 2017.

${ }^{175}$ BOUJIKIAN, M. A. Entrevista concedida a Stella Verzolla Tangerino. São Paulo, 6 jul. 2017.

${ }^{176}$ CRISPIM, R. DA C. Entrevista concedida a Stella Verzolla Tangerino. São Paulo, 5 jul. 2017.
} 
A maior contribuição do CPFF para mim foi entender como as relações afetivas estão e devem estar presentes em todos os âmbitos de nossas vidas. Eu pude descobrir que aprender também é estar emocionalmente e afetivamente envolvido, seja com a matéria, com a sala de aula, com a escola e até mesmo na amizade entre professores e alunos. ${ }^{177}$

Sobre esse tocante, a fala da professora Fabiana evoca um interessante nível de percepção presente na abordagem de ensino do Cursinho, comentada a seguir por Alvim Filho:

[..] a relação de afeto entre educadores e educandos aumenta, geralmente, a autoestima de alunos e alunas, pelas mesmas razões expostas acima, quando nos referimos às características de nossa sociedade industrial (a caminho, atropeladamente, de tornar-se pós-industrial). E, no caso de jovens e adultos, a reconquista, ou mesmo a conquista da autoestima é crucial para o desbloqueio de sérios impedimentos ao aprendizado, frequentemente decorrentes de insucessos pessoais e escolares. Assim, abre-se uma porta a dinamite e picaretas. ${ }^{178}$ (ênfase nossa)

Victor Augustus salienta como maior contribuição

o conjunto de companheiras e companheiros que esse projeto me apresentou. Estar rodeado de pessoas interessadas, dedicadas e comprometidas com a educação popular, além de grandes amizades e um crescimento pessoal imenso, abriu também portas profissionais. Sempre serei grato por ter a oportunidade de estar presentes com pessoas tão queridas e brilhantes durante meus anos formativos de professor e pessoa. ${ }^{179}$

O último recorte das entrevistas foi a narrativa sobre algo que tenha marcado fortemente o professor durante seus trabalhos no Cursinho. Sem dúvidas, ter acompanhado um aluno por todo o ano e ver seu ingresso nas universidades, públicas ou com bolsa nas instituições privadas é destacado por vários dos professores como fortemente significativo em suas trajetórias. Para além dessa experiência, foram ressaltados conquistas pessoais dos alunos, mudança de posicionamento frente às adversidades que enfrentam na vida civil, o nascimento do filho de uma das alunas, os primeiros empregos, saída da casa da família, descobertas em relação à sexualidade, entre outros movimentos.

A professora Lara conta-nos que

[...] houve momentos muito marcantes como o nascimento do filho de dois estudantes ou quando descobrimos que alguns alunos estão com problemas

${ }^{177}$ CABRAL, F. S. Entrevista concedida a Stella Verzolla Tangerino. São Paulo, 21 fev 2018.

${ }^{178}$ FILHO, H. A. Didática, formação docente e supervisão pedagógica nos CPVCs. In: CARVALHO; ALVIM FILHO; COSTA, Op. Cit., 2008, p. 78.

${ }^{179}$ VITAL, Victor Augustus. Entrevista concedida a Stella Verzolla Tangerino. São Paulo, 7 junho 2018. 
bem sérios, "expulso de casa por ser gay", assédio, racismo, crise de depressão, o que nos afeta de um jeito muito forte. ${ }^{180}$

Talita relata também uma experiência marcante vivida:

Olha, pensei em uma que aconteceu no sábado. Um aluno nosso, o Davi, queria fazer dança e o pai falava que isso era coisa de veado e no sábado ele me contou que saiu de casa e está trabalhando como cabelereiro e está muito apaixonado por essa profissão, trabalhando cabelo afro, o que traz também um empoderamento e veio falar o quanto o cursinho trouxe isso pra ele. Fiquei muito feliz. ${ }^{181}$

Caio Jonas ressalta: "No meu primeiro mês dando aula, ganhei uma caixinha de origami de uma aluna, que eu guardo comigo até hoje para guardar giz. Existem também algumas falas que me marcaram muito, como "você foi o melhor professor de matemática que eu tive" 182.

O professor Marcelo destaca o ganho profissional como traço marcante:

[...] O que aprendi em relação a educação e comunicação no CPFF, tento trazer para todos os contextos em que atuo, seja nas oficinas de arte-educação para crianças, no quilombo de Camburi, ou nas atividades editoriais que são minha profissão. Essas são marcas que espero levar pra sempre. ${ }^{183}$

Para o professor Victor,

o que mais me marca é ver ex-estudantes participarem do cursinho. Ver o potencial acadêmico daquelas pessoas sendo realizado na universidade e logo voltarem para o cursinho é profundamente recompensador. Além disso, pedagogicamente o cursinho só ganha tanto com as maneiras que enxergam e constroem novas práticas quanto à representatividade deles no quadro de professores e coordenadores. ${ }^{184}$

\footnotetext{
${ }^{180}$ ROCHA, L. S. Entrevista concedida a Stella Verzolla Tangerino. São Paulo, 23 junho. 2017.

${ }^{181}$ ZANATA, T. A. Entrevista concedida a Stella Verzolla Tangerino. São Paulo, 7 jul. 2017.

${ }^{182}$ DA SILVA, C. J. V. Entrevista concedida a Stella Verzolla Tangerino. São Paulo, 7 jul. 2017.

${ }^{183}$ BOUJIKIAN, M. A. Entrevista concedida a Stella Verzolla Tangerino. São Paulo, 6 jul. 2017.

${ }^{184}$ VITAL, Victor Augustus. Entrevista concedida a Stella Verzolla Tangerino. São Paulo, 7 junho 2018.
} 


\subsection{O estudante: vulnerabilidades e descoberta de direitos}

A gente fica meio perdida, de repente a gente até fala: é, eu acho que ela tem razão, porque sou pobre mesmo, não tenho condição, então, acho que tenho que ser tratada assim.

Edileusa, 46 anos. ${ }^{185}$

Tem a periferia rotulada que eu acho que é bem diferente da periferia vivida, não é? A rotulada é essa que é construída como discurso, como bode expiatório, como senzala, como quilombo no rap. Então, eu acho que é periferia polivalente. Dependendo da boca de quem ela está, ela vai ter um significado.

Luciana Dias, integrante do Coletivo Cinebecos e Vielas, em Video-lência, 2009

O aluno é o referente de toda ação educativa. Assim, toda atuação pedagógica que se pretenda democrática e humanizada, não importa se formal ou não formal, institucional ou não ${ }^{186}$, deveria aproximar-se o mais possível da realidade dos alunos, de suas necessidades e abrir-se à diferença, para a construção de um conhecimento significativo ${ }^{187}$ e estimulante. Do mesmo modo, "à medida que a sala de aula se torna mais diversa, os professores têm de enfrentar o modo como a política da dominação de reproduz no contexto educacional" ${ }^{188} \mathrm{e}$ muitos outros desafios que não param na porta do Cursinho.

As escolas das quais são egressos, públicas, na maioria das vezes são escassas em projetos que ensejem qualquer tipo de novidade à sua formação, seja provendo oficinas, mostras de filme, visitas a exposições e demais estruturas fora do contexto de uma sala de aula ${ }^{189}$,

${ }^{185}$ KOWARICK, L. Cortiços: reflexões sobre humilhação, subalternidade e movimentos sociais. In KOWARICK; FRUGOLI JR., Op. Cit., 2016, p. 180.

186 "Educar para outros mundos possíveis é fazer da educação, tanto formal, quanto não formal, um espaço de formação crítica e não apenas de formação de mão de obra para o mercado; é inventar novos espaços de formação alternativos ao sistema formal de educação e negar a sua forma hierarquizada numa estrutura de mando e subordinação". In: GADOTTI, Op. Cit., 2003, p. 98.

${ }^{187}$ Resume Ausubel: “[...] a essência do processo de aprendizagem significativa é que as idéias expressas, simbolicamente, são relacionadas às informações, previamente, adquiridas pelo aluno através de uma relação não arbitrária e substantiva". In: AUSUBEL; NOVAK; HANESIAN, Op. Cit., 1980, p. 34.

${ }^{188}$ HOOKS, Op. Cit., 2013, p. 56.

189 “"...] faltam espaços sociais e de vivencia cultural, sendo a escola pública (...) um dos únicos espaços públicos que restaram, pois a urbanização acelerada não foi acompanhada de investimentos públicos em equipamentos sociais e culturais. A iniciativa privada assumiu, em função de seus interesses, a criação de áreas de convívio, como shopping centers, concebidos para o consumo, mas que, por isso, promovem mais facilmente a segregação econômica que a vivencia cultural coletiva". In: MENEZES, L. C. de. O 
tornando-se muitas vezes espaços esvaziados de sentido, escancarando a obsolescência do aprendizado e com ele, dos próprios alunos. Alunos que na maioria das vezes tiveram dura jornada durante a semana, dividindo seu tempo entre estudo e auxílio na subsistência familiar e que também não conseguem, não raro, acessar os espaços de cultura e lazer disponíveis na cidade, ainda que gratuitos. ${ }^{190}$

Catelli Jr. lembra-nos, a esse respeito, que a própria

[..] lógica fragmentada de construção do conhecimento no âmbito escolar dificulta o desenvolvimento de propostas que levem, de fato, os educandos a refletir sobre as praticas sociais no âmbito dos temas e conceitos das ciências humanas. ${ }^{191}$

A propósito,

[...] O cursinho pré-vestibular é, geralmente, compreendido como local revisor do conteúdo programático do ensino de $2^{\circ}$ grau. Nessa "revisão", entretanto, muitas vezes os jovens deparavam-se com uma quantidade muito maior e mais profunda de informações do que aquela que acreditavam contemplar o currículo do ensino médio. Ficava novamente evidente um fato já tantas vezes estudado: a escola pública não parecia estar comprometida com a preparação, nem simbolicamente nem concretamente, para a universidade. ${ }^{192}$

O depoimento do aluno Genilson Farias, 19 anos, que frequentou o Florestan de fevereiro de 2015 a fevereiro de 2016, mostra-nos em riqueza de detalhes essa dinâmica:

Dezoito anos, terceiro ano do ensino médio, escola pública, período noturno,
jornada de trabalho em uma transportadora das $08: 00$ às 17:48. Não era o pior
aluno da classe, sempre tive médias boas, até o momento que você se depara
com a universidade. Um mundo novo que não é tratado nas condições citadas
acima. Universidade pública ou federal? O que é isso? Existe no Brasil? É de
graça? Essas informações não nós alcançam aonde estamos, na periferia. Ser
o aluno mediano não é o suficiente para as melhores universidades do país.
Poucos professores tem a coragem ou até mesmo dizendo, a audácia de inovar
em alguma aula por ano e apresentar algo inusitado aos alunos. Falar sobre
política? Não pode, precisamos saber apenas a responsabilidade dos 3 poderes
que regem a Nação. Cidadania? Não saberíamos nunca. Direito a cidade?

novo público e a nova natureza do Ensino Médio. Estudos avançados, São Paulo, v. 15, n. 42, 2001, p. 202.

${ }^{190}$ Taline Chaves conta-nos: "A primeira descoberta é que os alunos entrevistados que frequentam as aulas do cursinho tem um perfil, em geral, muito parecido, tendo principalmente como ponto comum o desconhecimento completo da educação de nível superior, de sua importância e dos caminhos para acesso, assim como a incapacidade de pagar uma faculdade privada ou ingressar numa universidade pública". In: CHAVES, T. Cursinho popular - Abrindo as portas do universo: jovens da periferia e os acessos à educação e ao mundo do trabalho. São Paulo, 2013. Iniciação científica - Pontifícia Universidade Católica, p. 9.

${ }^{191}$ CATELLI JR., R. Os direitos humanos e o currículo de ciências humanas na educação de jovens e adultos. In: CATELLI JR., Op. Cit., 2017, p. 126.

${ }^{192}$ SAFFIOTI, Op. Cit., 2008, p. 37. 
Nunca ouvimos falar! Racismo? LGBT fobia? Igualdade de gênero? Esses não são temas da "educação" tradicional pública. Agradeço a educação popular por abordar esses assuntos, por debater, estimular o senso crítico, oferecer as informações que não é nos alcançada. A importância da educação popular na minha vida foi de extremo bem na formação do cidadão que atualmente eu sou ou tendo ser a cada dia. Desconstruir preconceitos, acompanhar um mínimo sobre notícias políticas, economia e demais assuntos da nossa sociedade. Se não fosse isso, talvez a minha maior preocupação hoje seria se eu deveria ou não terminar o ensino médio. ${ }^{193}$

A fala de Genilson evidenciando que não há espaço para pensar temas diferentes nos currículos da educação regular remete-nos à interessante análise de Arroyo:

Há uma sociologia das ausências que exige nossa compreensão. Os subalternizados não apenas estiveram e estão ausentes nos padrões de poder, de justiça, de propriedade da terra, do solo, da renda, do trabalho; estiveram e estão ausentes do padrão de conhecimento, de ciência. Ausentes no pensamento sociológico e pedagógico. Ausentes no conhecimento curricular. Que indagações trazem para o repensar dos currículos esses processos de produzi-los como ausentes? Exigem um repensar crítico dos currículos dos conhecimentos escolares na produção dessas ausências, inexistências. ${ }^{194}$

Às diversas dificuldades de conteúdo enfrentadas na trajetória escolar pregressa ${ }^{195}$ somam-se outras: grande parte das vezes não há recurso suficiente para garantir o transporte ou uma alimentação para ficar o dia todo no Cursinho ${ }^{196}$. Sobre essa questão, a aluna Heloísa Estevo, 20 anos relata-nos em entrevista:

Não tinha dinheiro às vezes para condução e pra comida. Mesmo assim eu ia e dividia os lanches com os outros alunos. Tudo que aprendi eu levarei pra vida e pra minha vida universitária que eu espero que seja na USP. No Florestan eu tive esperança de que eu podia ser a mulher dos meus sonhos. Acho que é isso. ${ }^{197}$

\footnotetext{
${ }^{193}$ FARIAS, G. Entrevista concedida a Stella Verzolla Tangerino. São Paulo, 4 jun. 2018.

194 ARROYO, M. Os jovens, seu direito a se saber e o currículo. In: DAYRELL; CARRANO; LINHARES, Op. Cit., 2014, p. 181.

${ }^{195}$ Afirma Mendes: "Os alunos e suas histórias ficam, assim, contidos em um espaço no qual a escola procura não tornar muito visível, inclusive, os fracassos sucessivos na recuperação daquelas trajetórias". In: MENDES, G. M. L. Ainda sobre exclusão escolar. Teias, v. 12, n. 24, 2011, p. 32.

${ }^{196}$ A esse respeito, oportuna a consideração de Juan Cassasus: "A desigualdade de renda repercute em outras desigualdades sociais, tanto como acumulações do passado quanto como expressões que resultam da situação presente. A desigualdade de renda tem um impacto notório no acesso e na permanência da educação". In: CASASSUS, J. A escola e a desigualdade. Brasília/DF: Plano Editora, 2002, p. 38.

${ }^{197}$ ESTEVO, H. Entrevista concedida a Stella Verzolla Tangerino. São Paulo, 22 jun. 2018.
} 
Ainda mais aflitivo, é o discurso interno ${ }^{198}$ e a apropriação da condição de excluído que é travada pelo aluno, como ilustrado pelo depoimento de Edileusa, em epígrafe ${ }^{199}$, o qual revela todo o discurso social e a "naturalização das relações sociais" 200 , na concepção de Kowarick, pela qual "tudo é assim e continuará assim por uma espécie de sina, destino inelutável, do qual não se pode escapar, a não ser que se tenha muita sorte, decorrente de uma vontade divina" 201 reforça a condição de inferioridade que é sentida até mesmo no olhar para com eles e mais paredes se erguem.

O infográfico elencado abaixo ${ }^{202}$, datado de 27 de novembro de 2016, a partir do qual constatamos que a maioria dos alunos egressos de escola pública sequer inscreve-se para o vestibular da USP (Fuvest), seja por falta de informação seja por acreditar que tal exame esteja muito além de suas possibilidades, confirma essa dinâmica:

\footnotetext{
${ }^{198}$ Acerca desse discurso, remetemo-nos a VYGOTSKY, L. S. A formação social da mente. Trad. José Cipolla Neto, Luis S. M. Barreto, Solange, C. Afeche. $3^{\text {a }}$ ed. São Paulo: Martins Fontes, 1989.

${ }^{199}$ Edileusa é uma das entrevistadas por Lúcio Kowarick em interessante artigo sobre a humilhação de viver em cortiços do Centro de São Paulo Achamos que o depoimento se adequa com muita propriedade à condição de subalternidade e inferioridade que tratamos aqui, cf. KOWARICK, L. Cortiços: reflexões sobre humilhação, subalternidade e movimentos sociais. In: KOWARICK; FRÚGOLI JR., Op. Cit., 2016, p. 171.

200 "Trata-se de mecanismos às vezes sutis - as entradas sociais e de serviço dos prédios das classes médias e altas, abertamente excludentes, ou a impossibilidade de estudar com todos os malefícios reais e simbólicos decorrentes que acabam por fazer as pessoas interiorizarem e também aceitarem sua condição de inferioridade e marginalização: percebem-se como subalternos, e a subalternidade passa a ser um elemento estruturador do cotidiano de suas vidas", cf. KOWARICK, L. Cortiços: reflexões sobre humilhação, subalternidade e movimentos sociais. In: KOWARICK; FRÚGOLI JR., Op. Cit., 2016, p. 188.

${ }^{201}$ Ibid., p. 188.

${ }^{202}$ Extraído da reportagem "Aluno da rede pública nem tenta vestibular da USP”. Folha de S. Paulo, São Paulo, 5 mar. 2018.
} 


\section{AUTOEXCLUSÃo}

De 100 jovens, de 17 a 22 anos, na Grande SP...

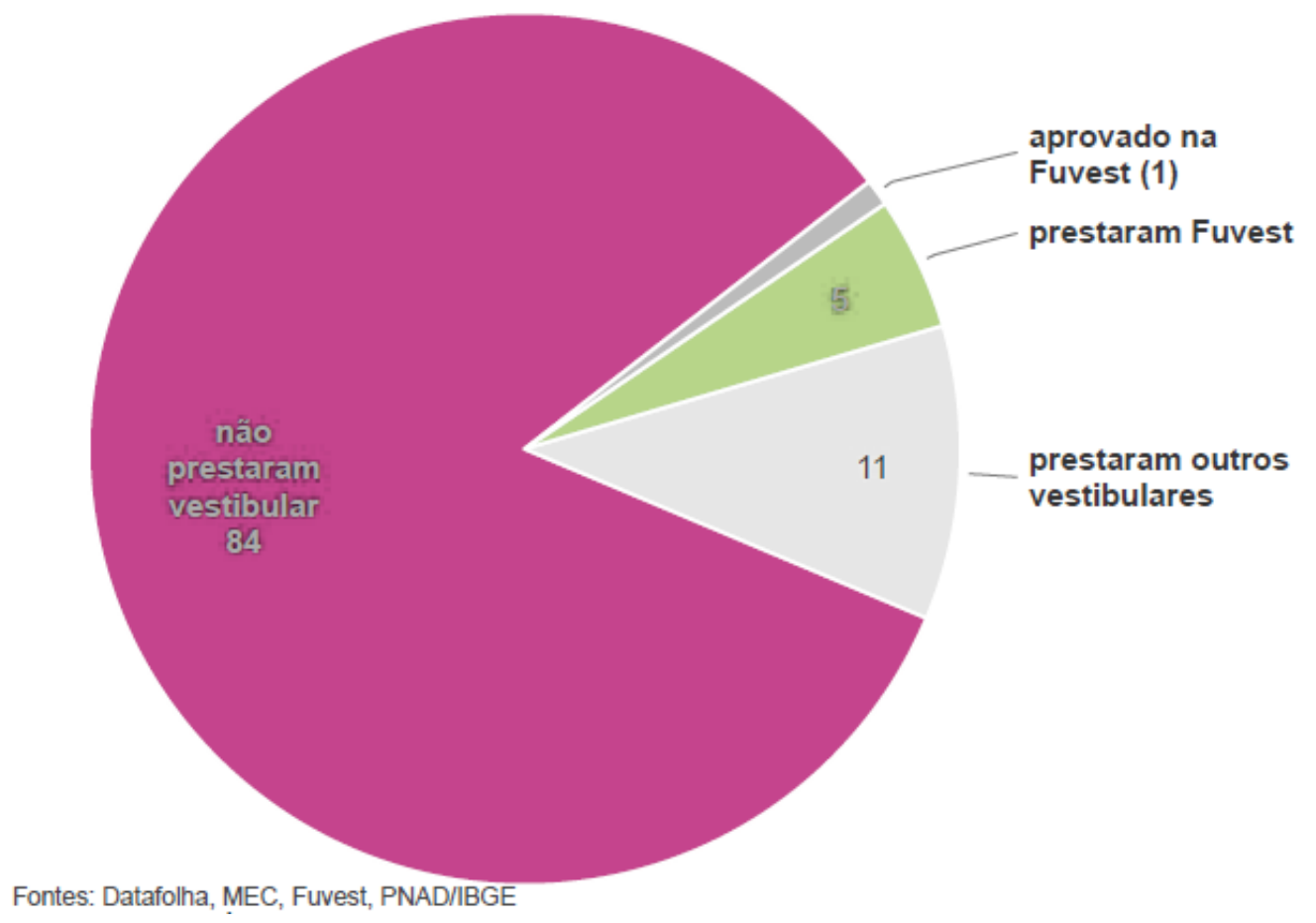

Gráfico 4 - Autoexclusão

Fonte: Datafolha, nov. 2016.

Mendes problematiza brilhantemente a questão dessa "naturalização" excludente sob o viés do vestibular:

Então a perspectiva é que maioria não passe..até se você seguir a linha do Paulo Freire, o nosso cursinho é para os que não vão passar mesmo. Por que as coisas são dessa forma? Por que você tem que fazer tudo...Por que você tem que ficar aqui o sábado inteiro, depois de passar por um vestibular que é totalmente excludente e às vezes nem cobra aquilo que ele acha importante...enfim, por que isso? Eu acho que essa é a questão, começar a indagar o porquê as coisas são dessa forma, porque a gente naturaliza muito as coisas, como se as coisas tivessem que ocorrer, que são assim e pronto. Na verdade, não se questiona o porquê elas são assim. Eu acho que esse é o papel do cursinho. Da educação em si. ${ }^{203}$ (ênfase nossa)

Nessa dimensão, impossível que não nos lembremos da noção de "violência simbólica" delineada por Bourdieu, segundo a qual,

\footnotetext{
${ }^{203}$ MENDES, M. T. Inclusão ou emancipação? Estudo de caso do Cursinho Chico Mendes/Rede Emancipa na Grande São Paulo. Porto Alegre, 2011. Dissertação (Mestrado em Educação) - Faculdade de Educação, Universidade Federal do Rio Grande do Sul, p. 92.
} 
[...] os sistemas simbólicos cumprem a sua função política de instrumentos de imposição ou de legitimação da dominação, que contribuem para assegurar a dominação de uma classe sobre a outra (violência simbólica) dando o reforço da sua própria força às relações de força que as fundamentam e contribuindo assim, segundo a expressão de Weber, para a domesticação dos dominados. ${ }^{204}$

O compromisso da Educação popular como ferramenta político-pedagógica nesse contexto, passa antes da preparação do aluno para os conteúdos formais que lhe serão exigidos nos exames do vestibular, por um trabalho de resgate da autoestima e consequente desconstrução da auto desvalia que lhe é inculcada nos anos escolares, pela comunidade e até mesmo no seio família ${ }^{205}$; os chamados "recortes de ordem simbólica, transmitidos por professores, empregadores e grande parte da mídia" na expressão de Saffioti²06, que acabam demarcando e interditando lugares que podem ou não acessar. É esse "trabalho de base", que sustentará o que se pretende em um momento posterior: a tomada de consciência.

O trabalho de base é parte indispensável da luta popular. O trabalho de base é a condição e o sustento do trabalho político e do trabalho de massa: o trabalho político e o trabalho de massa devem ser a expressão e a consequência do trabalho de base. $O$ trabalho de base é a ação política transformadora, realizada por militantes de uma organização popular, que mete o corpo em uma realidade concreta, para despertar, organizar o povo na solução de problemas do cotidiano e ligar essa luta à luta geral contra a opressão. ${ }^{207}$

Destacamos também;

[...] os $\mathrm{PVPs}^{208}$ procuram fazer frente ao processo preparatório ao vestibular, revisando os conteúdos pertinentes a um bom desempenho de seus alunos. Porém, junto com essa tarefa que é intrínseca a um pré-vestibular, os cursinhos populares procuram se constituir como espaços de capacitação crítica das classes populares, oferecendo com base no trabalho voluntário e militante de licenciados e estudantes universitários, na maioria das experiências, um espaço de educação crítica. ${ }^{209}$

\footnotetext{
${ }^{204}$ BOURDIEU, P. O poder simbólico. Rio de Janeiro: Bertrand Brasil S.A, 1989, p. 11.

205 "Além do ensino para o vestibular, as práticas dos cursos pré-vestibulares populares apresentam elementos interessantes. Um deles é a proposta de realizar uma pedagogia que contribua para fortalecimento de autoestima, para construção de identidade (negra, popular, etc) e para desenvolvimento de autonomia com vistas a um posicionamento critico diante da dinâmica social". In: NASCIMENTO, Op. Cit., 2012, p. 93.

${ }^{206}$ SAFFIOTI, Op. Cit., 2008, p. 153.

${ }^{207}$ PELOSO, Op. Cit., 2012, p. 10.

${ }^{208}$ Pré-Vestibulares Populares (PVP's).

${ }^{209}$ PEREIRA, T. I. Pré-vestibulares populares em Porto Alegre: na fronteira entre o público e o privado. Porto Alegre, 2007. Dissertação (Mestrado em Educação) - Universidade Federal do Rio Grande do Sul, p. 52.
} 
Um elemento comum destacado nas várias entrevistas colhidas dos alunos é justamente a possibilidade de abertura que esse novo locus, proporcionou a eles. Estar em um ambiente diferente da escola formal, em uma relação de mais horizontalidade com os professores do cursinho, também distinta da relação com o docente da escola de origem, conhecer outras pessoas $^{210}$ com trajetórias e sonhos semelhantes ${ }^{211}$, participar das celebrações, dos debates, é como um catalisador para alimentar as transformações ${ }^{212}$ que se darão ao longo do exercício letivo e ressignificar a precariedade simbólica do sentido de estudar, como nos conta a aluna Eduarda Ribeiro Rodrigues, 23 anos, que atualmente cursa História na USP, fazendo parte do quadro de professores do Florestan: "mesmo já cursando o ensino superior me matriculei, além da parte pedagógica o cursinho me impulsionou em outros setores, fiz grandes amizades tanto é que hoje faço parte do grupo de professores".

É oportuna a referência de Maíra Tavares,

Por mais que aquele aluno não passe no vestibular, se ele não passar no vestibular, uma grande parte do nosso objetivo foi atingida, porque ele termina o ano tendo outra visão de mundo. Ele tem outra visão de sociedade, ele tem outra visão de trabalho em equipe, ele tem outra visão de trabalho comum, de trabalho coletivo. Ele tem outra percepção dele mesmo na sociedade, ele percebe que pode construir, que pode mudar, que ele é dono das vontades dele, das idéias dele. Que a partir do momento que ele se junta a outras pessoas ele consegue mudar as coisas, ele consegue transformar a realidade. Não é mais um aluno com vendas nos olhos. (ênfase nossa $)^{213}$

\footnotetext{
${ }^{210}$ SANTOS et al dizem-nos que "[...] as populações jovens não são homogêneas, os jovens compõem diversos grupos - juventudes - caracterizados por suas condições de vida, interesses e escolhas. Os modos de experimentar condições e estados de juventude não são vividos da mesma forma pelos grupos juvenis". In: SANTOS et al. Jovens urbanos: sistematização de uma metodologia. São Paulo: CENPEC, 2008, p. 14.

${ }^{211}$ Veja-se: "Nos cursos pré-vestibulares populares, o ensino de conteúdos para o vestibular, as reflexões sobre educação e sociedade, as reuniões para socialização de informações, troca de experiências e decisões políticas, a construção de propostas de políticas públicas, as práticas de negociação, os encontros e seminários são formas de luta". In: NASCIMENTO, Op. Cit., 2012, p. 85.

212 "O aprendizado é um processo de busca e descoberta, de grande empolgação e intimidade - e tudo isso é muito difícil de transmitir aos outros. Acredito que todo aprendizado é a descoberta de algo novo. A experiência da descoberta, o momento em que você descobre algo novo - encontrar uma planta que eu esteja procurando havia tempos, esbarras num livro que eu nunca vi antes... ou qualquer outra descoberta, seja sobre o mundo ou sobre mim mesmo - é uma das experiências mais poderosas e comoventes que existem". In: HECHT, Y. Educação democrática: o começo de uma história. Trad. Adriana Scandolara. Belo Horizonte: Autêntica, 2016, p. 74.

${ }^{213}$ MENDES, Op. Cit., 2011, p. 93.
} 
Jovens que inicialmente não possuíam sequer um "lugar de voz"214, de expressão, articulando-se para expor suas ideias, entendendo melhor sua cidade, questões de gênero, de raça, dos arranjos de poder da sociedade ${ }^{215}$. Dirá Freire que “[...] os oprimidos, nos vários momentos da sua libertação, precisam reconhecer-se como homens, na sua vocação ontológica e histórica de ser mais. A reflexão e a ação se impõem, quando não se pretende, erroneamente, dicotomizar o conteúdo da forma histórica". 216

É uníssono nos relatos a percepção, pelos alunos, de uma melhora em suas capacidades critica, argumentativa e de visão de mundo estimulada pelas atividades do Cursinho, promotoras de uma "cidadania ativa" 217 e pela confiança passada pelos professores em seu potencial, afinal, não é novidade na pedagogia a constatação de que mesmo em cenários adversos, a crença na capacidade dos alunos é um diferencial para potencialização da aprendizagem. $^{218}$

Até porque, há muito se sabe que

Não faz sentido pressupor um trajeto único e obrigatório para todos os sujeitos em seus processos de aprendizagem. Cada um tem uma forma própria e singular de tecer conhecimentos através dos modos como atribui sentido às informações recebidas, estabelecendo conexões entre os fios e tessituras anteriores e os novos. ${ }^{219}$

A aluna Camila Pereira, 19 anos, conta-nos:

${ }^{214}$ A esse respeito, destacamos uma instigante reflexão de Hooks: "Deve-se distinguir entre uma compreensão rasa do ato de encontrar a própria voz, que dá a entender erroneamente que haverá uma democratização da voz onde todos terão o mesmo tempo para falar e suas palavras serão vistas como igualmente valiosas e um reconhecimento mais complexo da singularidade de cada voz e a disposição de criar espaços em aula onde todas as vozes podem ser ouvidas porque todos os alunos são livres para falar, sabendo que sua presença será reconhecida e valorizada". In: HOOKS, Op. Cit., 2013, p. 246.

${ }^{215}$ Aludimos à Brandão: "Excluídos da escola e defasados da educação, sujeitos das classes populares são para não serem regularmente educados, porque, em uma sociedade capitalista dependente, uma igualdade social de oportunidades de educação ameaçaria a necessidade política e econômica da desigualdade de oportunidades de participação na vida, no trabalho e no poder”. In: BRANDÃO, C. R. Revista de educação de adultos, México, v. 2, n. 2, 1984, p. 32-33.

${ }^{216}$ FREIRE, P. Pedagogia do oprimido. Rio de Janeiro: Paz e Terra, 1996, p. 57.

${ }^{217}$ BENEVIDES, M. V. A cidadania ativa: referendo, plebiscito e iniciativa popular. São Paulo: Ática, 1991.

${ }^{218}$ Referimo-nos ao estudo de Robert Rosenthal e Lenore Jacobson, "Pygmalion in the Classroom" publicado em 1968, que relaciona a influência do desenvolvimento do aluno à postura e expectativa de seus professores, cf. ROSENTHAL, R.; JACOBSON, L. Pygmalion in the Classroom: Teacher expectation and pupils' intellectual development. Reino Unido: Crown House Publishing, 2003.

${ }^{219}$ OLIVEIRA, I. B. de. Organização curricular e práticas pedagógicas na EJA: algumas reflexões. In: PAIVA, J.; OLIVEIRA, I. B. de (Org). Educação de jovens e adultos. Petrópolis: De Petrus et Alli Editora, 2009, p. 98-99. 
O cursinho popular Florestan Fernandes mudou bastante coisa em minha vida, principalmente a maneira de ver o mundo, me ensinou coisas que até então nunca tinha visto em nenhum outro lugar. Além de matérias básicas do ensino médio, me fez debater sobre temas que nem sequer tinha parado para problematizar. Além de ter ótimos professores que me ajudaram muito não só no cursinho mais fora dele, são amigos que vou levar para o resto da vida. ${ }^{220}$

Para Victoria Caroline da Silva Pereira, 18 anos,

O Cursinho me ensinou a conhecer várias coisas, abrir meus olhos para o horizonte onde temos várias possibilidades, nos ensinar de várias maneiras. A aula da professora Stella era cada uma mais criativa que a outra fazendo com a seus alunos esperassem sua aula cada vez mais e nos mostrando o mundo com outro olhar. ${ }^{221}$

Sarah Alves, 18 anos também aborda essa abertura, trazida pelo Cursinho:

O cursinho foi importante pra mim principalmente para focar em muitas coisas, que não fazia a mínima ideia que poderia me afetar e tive a oportunidade de conhecer coisa, matéria, pessoa novas, que me ajudaram a entender muitas matérias que tive dificuldade. Gostei muito porque hoje posso ter um conhecimento mais amplo. ${ }^{222}$

Igor Souza, 17 anos conclui:

O CPFF oferece um local seguro onde você pode se expressar sem nenhuma represália; aborda temas político-sociais para dar visibilidade as minorias e apontar os erros dos opressores o que ajuda na formação do pensamento crítico do estudante. [...] O CPFF me ensinou a ter empatia, ser mais tolerante, me mostrou outras realidades de vida e experiências de vida de pessoas diferentes. ${ }^{223}$

Em boa parte das narrativas, dá-se a ver também essa ampliação de horizontes vivenciada no Cursinho como criadora de um "valor coletivo",224 a partir do qual, apropriam-se e disseminam em outros signos e significados da vida fora da sala de aula.

É justamente ao que alude Fantin:

[...] os projetos de mudança embutidos nestas experiências atingem tanto o nível macro, ou seja, de ampliar o número de jovens universitários em todo o

\footnotetext{
${ }^{220}$ PEREIRA, C. Entrevista concedida a Stella Verzolla Tangerino. São Paulo, data 18 jul. 2017.

${ }^{221}$ PEREIRA, V. C. da S. Entrevista concedida a Stella Verzolla Tangerino. São Paulo, 18 jul. 2017.

${ }^{222}$ ALVES, S. Entrevista concedida a Stella Verzolla Tangerino. São Paulo, 18 jul. 2017.

${ }^{223}$ SOUZA, I. Entrevista concedida a Stella Verzolla Tangerino. São Paulo, 20 fev. 2018.

${ }^{224}$ Sobre o valor coletivo, explica-nos Gallo: "Na educação menor todo ato adquire um valor coletivo. O educador-militante, ao escolher sua atuação na escola, estará escolhendo para si e para todos aqueles com os quais irá trabalhar. Na educação menor, não há a possibilidade de atos solitários, isolados; toda ação implicará em muitos indivíduos. Toda singularização será, ao mesmo tempo, singularização coletiva”. In: GALLO, Op. Cit., 2002, p. 176.
} 
país, como o micro, onde cada pessoa faz uma pequena parte dessa mudança; são experiências de resistência que rompem com o conformismo e a acomodação; na sua grande maioria, são experiências autogestadas, onde jovens que usufruíram do curso preparatório, e que através desse espaço adquiriram consciência da importância de lutar pelo direito à educação [...] já experimentam uma dentre tantas formas de ser sujeitos coletivos, não mais apenas e tão somente indivíduos. ${ }^{225}$

\subsubsection{Contexto sócio econômico e discussão dos resultados}

Alguns indicadores socioeconômicos inseridos no questionário de matrícula aplicado no início dos períodos letivos (janeiro e julho) nos permitem melhor compreensão do perfil dos nossos alunos. Separamos quatro eixos extraídos desses questionários relativos respectivamente a janeiro de 2017 (extensivo), julho de 2017 (intensivo) e janeiro de 2018 (extensivo).

Da análise dos gráficos, torna-se possível destacar os elementos estruturantes que nos do perfil socioeconômico do estudante: composição do núcleo familiar, renda familiar, quantas pessoas contribuem para esse rendimento e como o aluno chega até o Cursinho. Vale destacar que, "esse somatório de precariedades que, para além das simples linhas de pobreza, expressa as condições de vulnerabilidade social, inscritas em determinados territórios da cidade". 226

$\mathrm{Na}$ abordagem dos primeiros níveis de análise (núcleo familiar e renda), temos que o núcleo familiar predominante dos alunos do Cursinho Florestan Fernandes é composto por quatro pessoas; o que reflete uma baixa densidade domiciliar, com renda de um a dois salários mínimos, providos por majoritariamente duas pessoas da família, o que os inscreve na categoria de vulnerabilidade social.

Com relação ao transporte, prevalece a utilização do metro, seguido pelos ônibus municipais para deslocamento da residência até o Cursinho.

Os gráficos 05, 06, 07 referenciados abaixo, aludem às matrículas dos alunos de janeiro de 2017, trazendo o núcleo familiar composto por 04 pessoas como dominante, com 33,9\%, seguido de 03 pessoas (23,5\%). Acerca da renda média, a predominância foi a 1-2 salários mínimos $(42,6 \%)$, provida por uma a duas pessoas $(44,5 \%)$.

${ }^{225}$ FANTIN et al. Feito a lápis: experiências de educação popular na universidade. Cadernos de Pesquisa, São Paulo, 2004.

${ }^{226}$ SÃO PAULO (Município). Secretaria de Assistência Social. Mapa da Vulnerabilidade Social da População da Cidade de São Paulo. São Paulo: Cebrap, SESC e SAS-PMSP, 2004, p. 35. 


\section{Quantas pessoas compõem o seu núcleo familiar?}

\subsection{2 respostas}

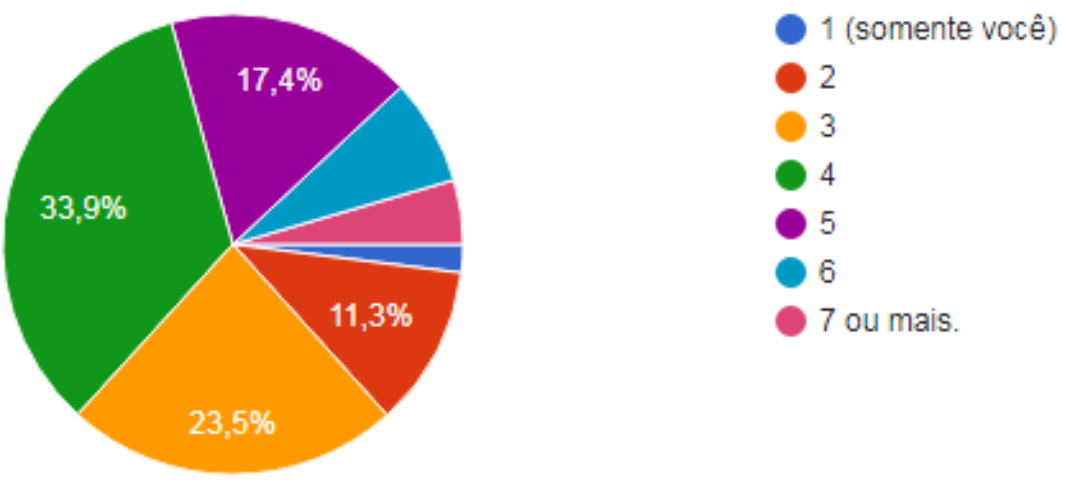

Gráfico 5 - Quantas pessoas compõem o seu núcleo familiar?

Fonte: Questionário socioeconômico - Matrícula extensivo de janeiro de 2017

\section{Qual a renda média da sua família?}

\subsection{2 respostas}

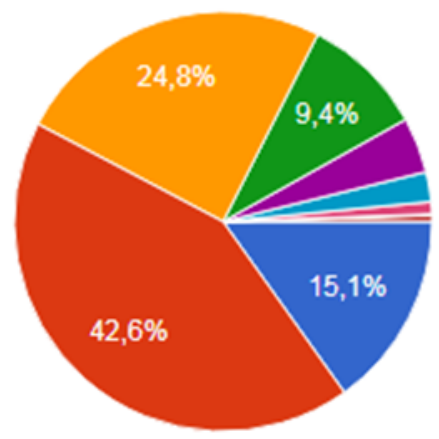

Até 1 salário mínimo

1 a 2 salários mínimos

2 a 3 salários mínimos

3 a 4 salários mínimos

4 a 5 salários mínimos

5 a 6 salários mínimos

7 a 8 salários mínimos

8 a 9 salários mínimos

Mais de 9 salários mínimos.

Gráfico 6 - Quantas a renda média da sua família?

Fonte: Questionário socioeconômico - Matrícula extensivo de janeiro de 2017 


\section{Quantas pessoas contribuem para a renda familiar?}

\subsection{2 respostas}
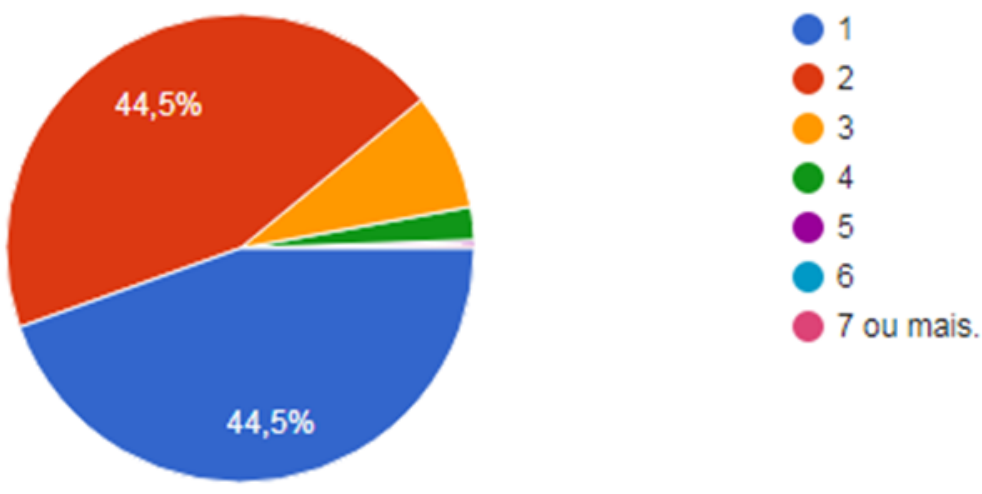

Gráfico 7 - Quantas pessoas contribuem para a renda familiar?

Fonte: Questionário socioeconômico - Matrícula extensivo de janeiro de 2017

O gráfico 08 mostra-nos que a opção majoritária para chegar ao cursinho para os alunos matriculados em janeiro de 2017 foi o ônibus municipal, sendo que 39,1\% serviu-se de apenas um deles e 38,3\% utilizaram dois ônibus.

Quais conduções você utilizará para chegar ao cursinho?

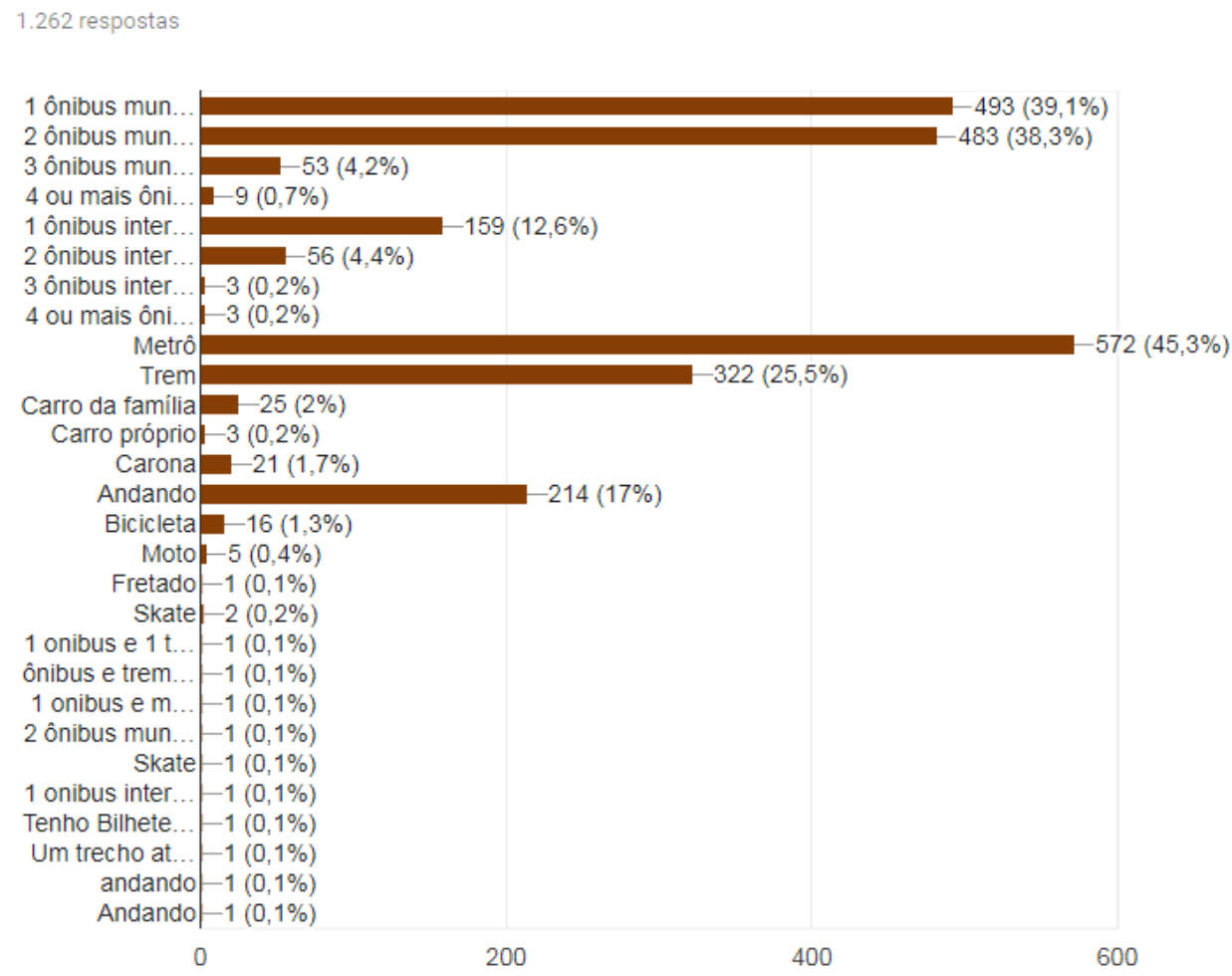

Gráfico 8 - Quantas conduções você utilizará para chegar ao cursinho?

Fonte: Questionário socioeconômico - Matrícula extensivo de janeiro de 2017. 
Os gráficos 09, 10, 11 na sequência, trazem as informações sobre os estudantes inscritos em julho de 2017 no Florestan. O núcleo familiar continua composto por 04 pessoas como opção majoritária no gráfico, com 28,7\%, seguido de 03 pessoas (27,8\%). Acerca da renda média, a predominância foi a 1-2 salários mínimos $(47,9 \%)$, provida por duas pessoas $(45,1 \%)$ e somente por uma com $43,7 \%$.

\section{Quantas pessoas compõem o seu núcleo familiar?}

428 respostas

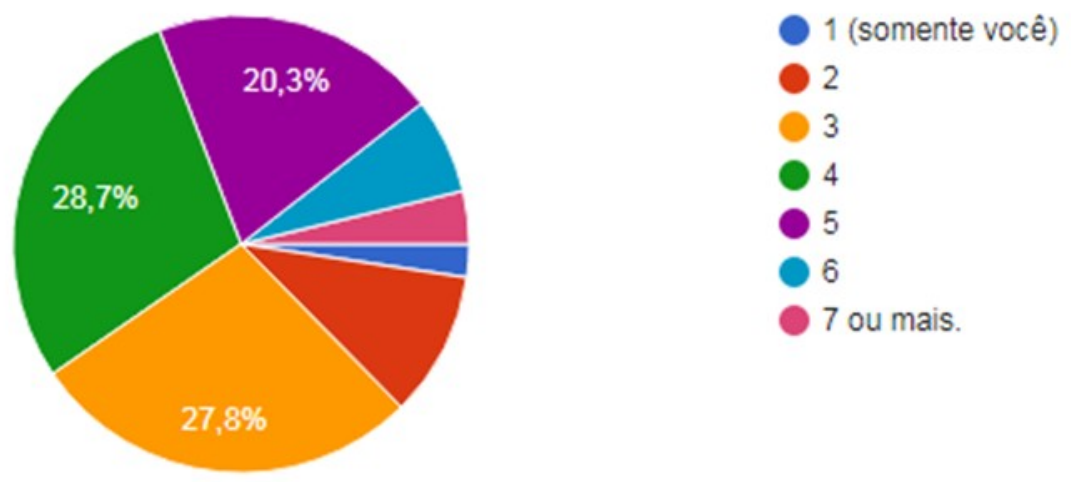

Gráfico 9 - Quantas pessoas compõem o seu núcleo familiar?

Fonte: Questionário socioeconômico - Matrícula intensivo de junho de 2017.

\section{Qual a renda média da sua família?}
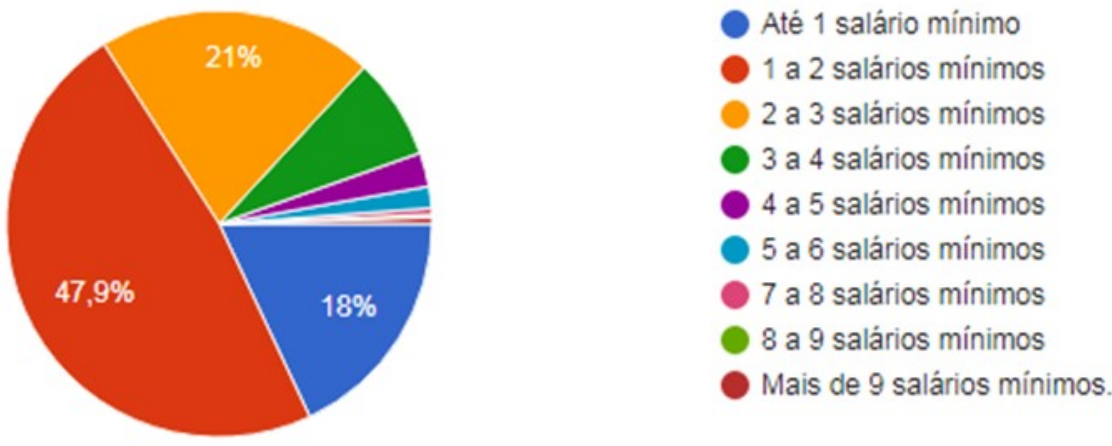

Gráfico 10 - Quantas a renda média da sua família?

Fonte: Questionário socioeconômico - Matrícula intensivo de junho de 2017. 


\title{
Quantas pessoas contribuem para a renda familiar?
}

\author{
428 respostas
}

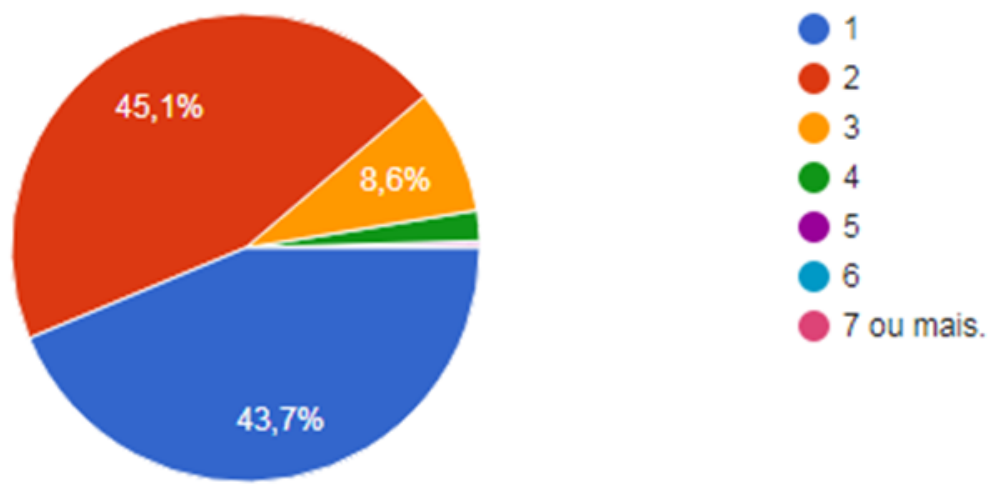

Gráfico 11 - Quantas pessoas contribuem para a renda familiar?

Fonte: Questionário socioeconômico - Matrícula intensivo de junho de 2017.

Em relação ao transporte, o gráfico 12 mostra-nos que o ônibus municipal prevalece como opção para chegar ao cursinho, sendo neste caso maior o uso de pelo menos dois deles $(40,2 \%)$.

\section{Quais conduções você utilizará para chegar ao cursinho?}

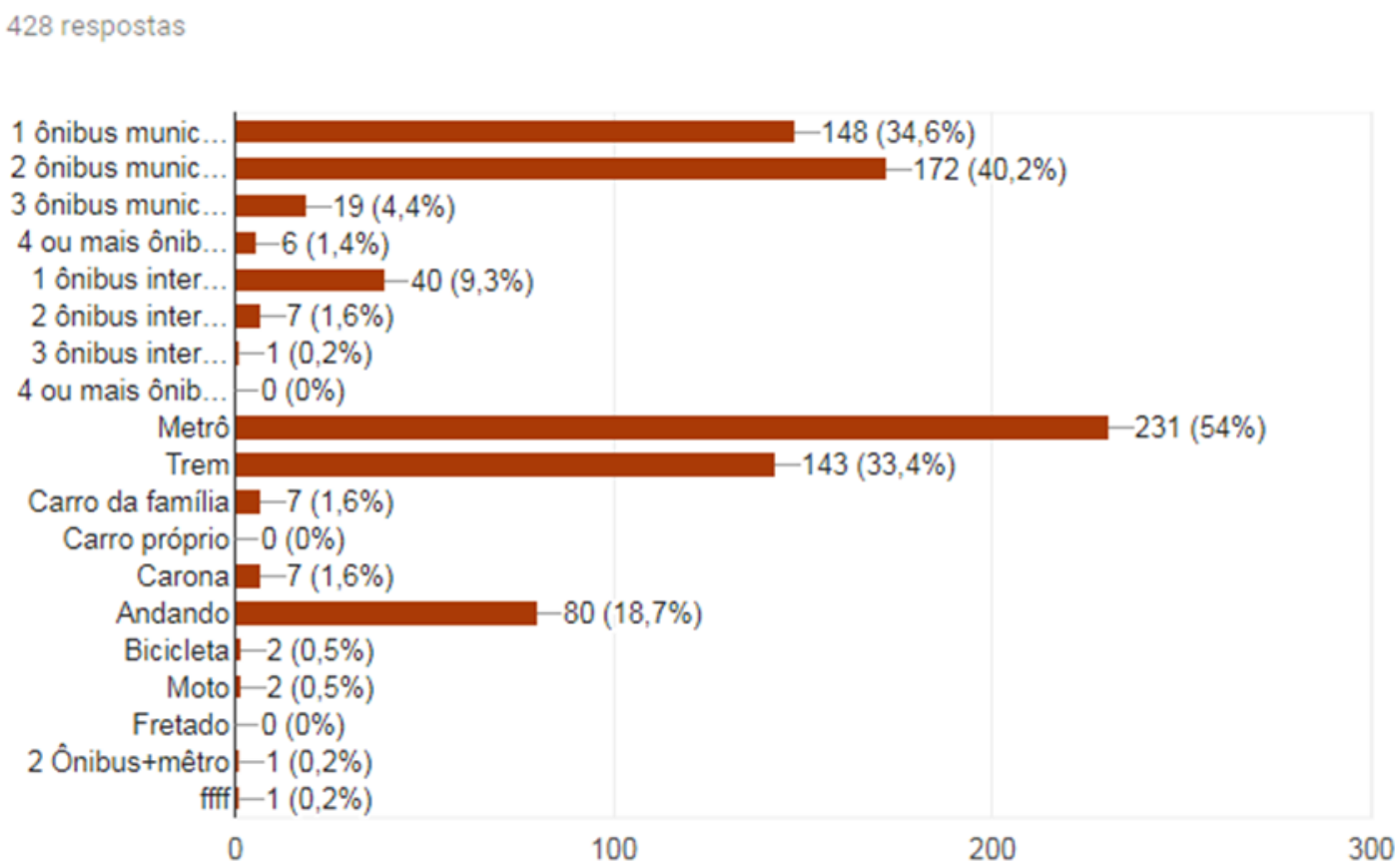

Gráfico 12 - Quantas conduções você utilizará para chegar ao cursinho?

Fonte: Questionário socioeconômico - Matrícula intensivo de junho de 2017. 
Os gráficos 13, 14 e 15, indicam a situação dos alunos matriculados em janeiro de 2018, sendo que acerca do núcleo familiar, temos a composição habitual de 04 pessoas como mais expressiva nas respostas $(39,8 \%)$, seguido de 03 pessoas $(23,5 \%)$. Acerca da renda média, a predominância foi a de R\$ 789,00 a R\$ 1576,00 (40\%), provida por duas pessoas $(43,6 \%)$ seguido da opção de apenas uma com $42,7 \%$.

\section{Quantas pessoas compõem o seu núcleo familiar?}

\section{8 respostas}
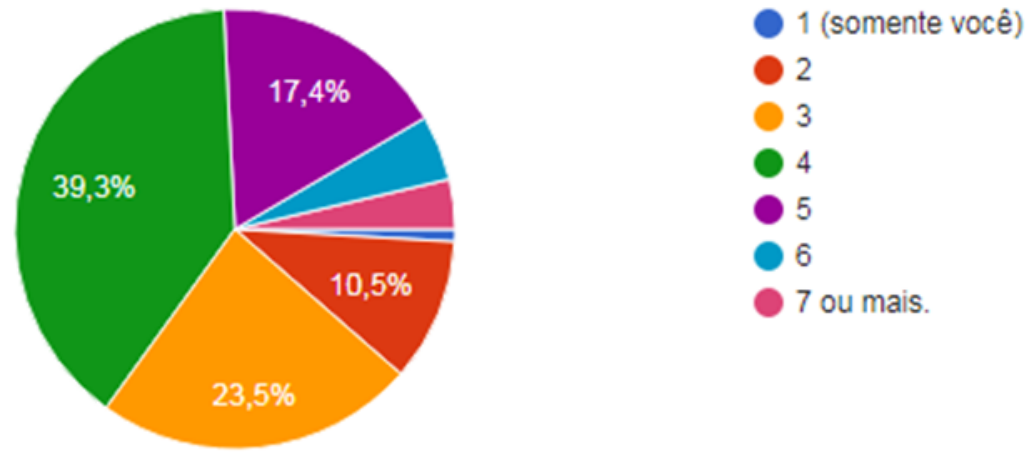

Gráfico 13 - Quantas pessoas compõem o seu núcleo familiar?

Fonte: Questionário socioeconômico - Matrícula extensivo de janeiro de 2018.

\section{Qual a renda média da sua família?}

\section{8 respostas}

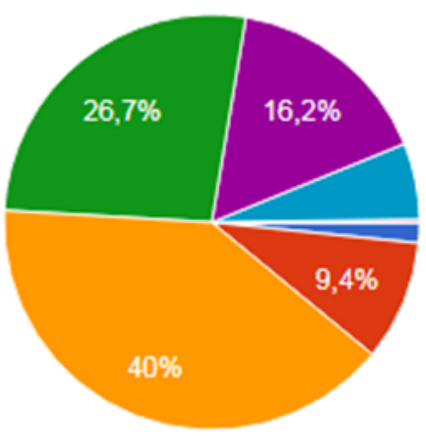

RS 1,00 a R\$ 394,00

RS 395,00 a RS 788,00

RS 789,00 a RS $1.576,00$

RS $1.577,00$ a RS $2.364,00$

RS $2.365,00$ a RS $3.940,00$

RS $3.941,00$ a RS $7.880,00$

RS $7.881,00$ a RS $15.760,00$

RS $15.761,00$ ou mais

Gráfico 14 - Quantas a renda média da sua família?

Fonte: Questionário socioeconômico - Matrícula extensivo de janeiro de 2018. 


\section{Quantas pessoas contribuem para a renda familiar?}

\section{8 respostas}

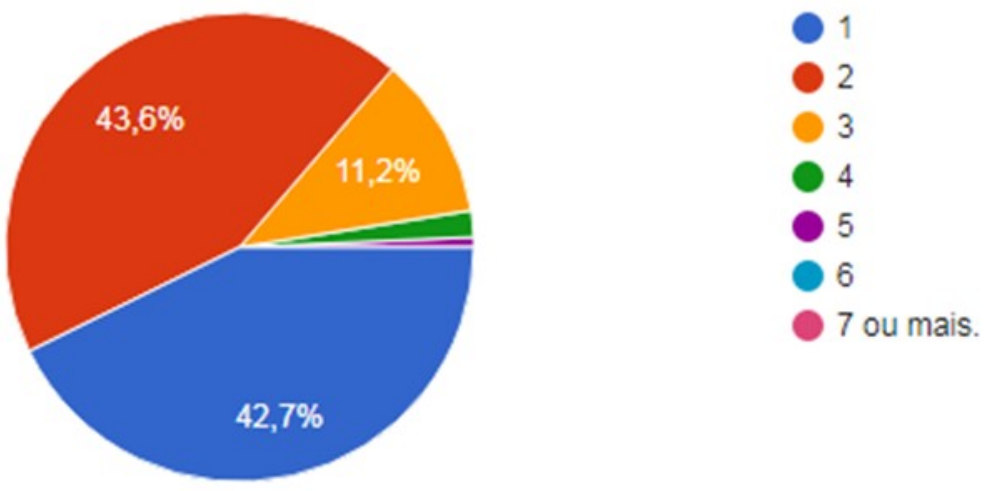

Gráfico 15 - Quantas pessoas contribuem para a renda familiar?

Fonte: Questionário socioeconômico - Matrícula extensivo de janeiro de 2018.

Por fim, o gráfico 16, é indicativo da prevalência de 02 ônibus municipais para chegada do estudante no Cursinho (37,9\%).

Quais conduções você utilizará para chegar ao cursinho?

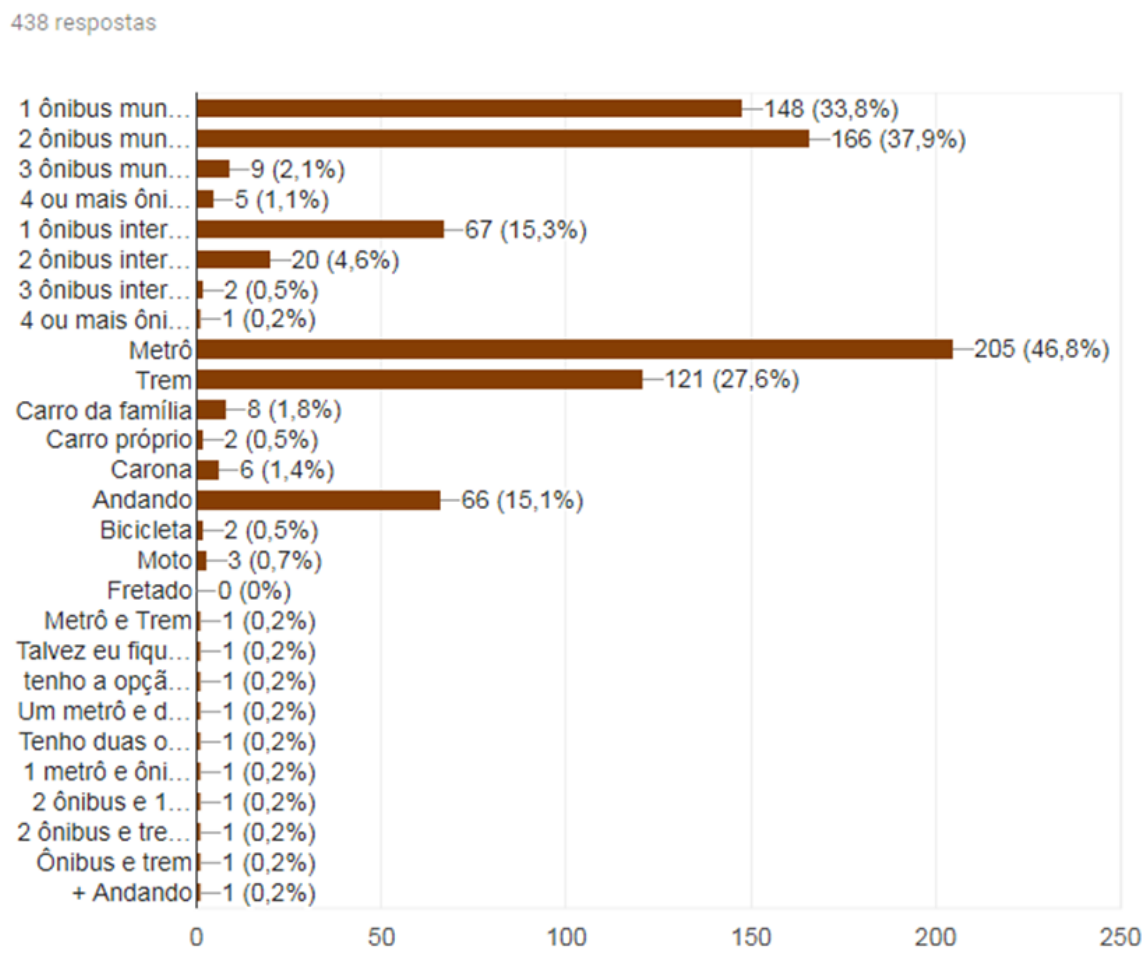

Gráfico 16 - Quantas conduções você utilizará para chegar ao cursinho?

Fonte: Questionário socioeconômico - Matrícula extensivo de janeiro de 2018 


\section{CAPÍTULO 3: Ensinar filosofia no cursinho popular - Convergência política e pedagógica}

Em oposição aos filósofos acadêmicos que, quando se fala sobre a forma de pensar corretamente, vão logo exigindo a leitura preliminar do Discurso do Método, de Descartes, eu digo: basta abrir bem os olhos!

Rubem Alves $^{227}$

\subsection{Nossa trajetória e desenvolvimento do tema}

Delimitada a micro-história do Cursinho, seus atores, como se colocam no espaço urbano, retomamos aqui, e em diálogo entre si, a análise da educação popular abordada nos capítulos anteriores sob ângulo distinto: o ensino de Filosofia no Florestan Fernandes, decorrente da própria condição de filósofa da autora, no dizer de Leroi-Gourhan, "toda teoria é um pouco auto-retrato". 228

Trata esse capítulo, portanto, das observações de seis anos de atividade docente no Florestan Fernandes, as quais possibilitaram a consolidação das impressões de nossas praticas pedagógicas e a percepção das singularidades dos alunos face ao ensino da Filosofia: dificuldades, desistência, temas que mais os entusiasmam, construção de novos sentidos para o olhar filosófico.

O "discurso da memória"229, diz-nos Beatriz Sarlo, "tem a ambição da autodefesa; quer persuadir o interlocutor presente" ${ }^{\text {230 }}$, mas é remediado aqui pelo discurso livre colhido nas entrevistas com os alunos. Notamos que concluídas as aulas, de maneira informal, no corredor ou na improvisada "sala dos professores", muitos estudantes vinham falar animadamente conosco sobre suas impressões, sobre como estavam gostando da matéria.

Cuidando para não influenciar tais depoimentos, buscamos sistematizamos um roteiro para organizar esses relatos, obtidos durante o primeiro semestre de 2018. Privilegiou-se abordar as principais diferenças entre o ensino da Filosofia no Cursinho e na escola onde o

\footnotetext{
${ }^{227}$ ALVES, R. Livro sem fim. São Paulo: Editora Loyola; 2002.

${ }^{228}$ LEROI-GOURHAN, A. Les racines du monde. Paris: Pierre Belfond, 1982, p. 11.

${ }^{229}$ SARLO, B. Tempo passado: cultura da memória e guinada subjetiva. Trad. Rosa Freire d'Aguiar. São Paulo: Companhia das Letras; Belo Horizonte: UFMG, 2007, p. 51.

${ }^{230}$ Ibid., p. 51.
} 
aluno cursa ou já concluiu o Ensino Médio e se o aluno já havia tido contato com essa disciplina anteriormente ao Cursinho.

Nossa leitura para o ensino da Filosofia é o da via aberta para discussão dos temas e ensaios visando a construção de um olhar livre: sem um "apelo nostálgico"231 de esgotar o conhecimento de toda uma história da filosofia trazida pronta, acabada e demasiado distante da compreensão e do interesse de um adolescente do Ensino Médio, de mostrar um "reduto de visões mortas", nas palavras de Paul Válery. ${ }^{232}$

Nietzsche já antecipava essa beleza de deixarmos algumas incompletudes na construção do pensamento filosófico:

\begin{abstract}
Assim como as figuras em relevo fazem muito efeito sobre a imaginação por estarem como que a ponto de sair da parede e subitamente se deterem, inibidas por algo: assim também a apresentação incompleta, como um relevo, de um pensamento, de toda uma filosofia, é às vezes mais eficaz que a apresentação exaustiva: deixa-se mais a fazer para quem observa, ele é incitado a continuar elaborando o que lhe aparece tão fortemente lavrado em luz e sombra, a pensá-lo até o fim e superar ele mesmo o obstáculo que até então impedia o desprendimento completo. (ênfase nossa). ${ }^{233}$
\end{abstract}

\title{
3.2 Propedêutica ao olhar filosófico
}

Fazer Filosofia, conta-nos Benedito Nunes, difere de fazer um banco de madeira. Isso porque, no mundo grego, a Filosofia não integrava o poieîn, "o fazer produtivo", mas seria antes, uma reeducação do olhar: “[...] ver o que está diante de nós, de maneira abrangente, como num espetáculo, exigindo mais do que a visão sensível - um ver intelectual" ${ }^{\text {234 }}$, encontrar um Rembrandt por sob uma pintura que o encobria. ${ }^{235}$

O espaço de ação livre proporcionado pelo Cursinho, sem as amarras curriculares dos ambientes formais de educação é a princípio favorável a esse despertar contemplativo nos alunos, mas exige crítica e sensibilidade. A Filosofia no Cursinho deve desenvolver nos alunos aquele outro olhar, como queriam os gregos, abrir-lhes um repertório novo para ler os signos

\footnotetext{
${ }^{231}$ JAMESON, F. Fim da arte ou fim da história. In: A cultura do dinheiro: ensaios sobre a globalização. Petrópolis: Vozes, 2001, p. 91.

${ }^{232}$ VALERY, P. O problema dos museus. Trad. V. Novis. Revista MAC, São Paulo, n. 2, nov. 1993, página 21.

${ }^{233}$ NIETZSCHE, F. Crepúsculo dos ídolos, ou Como se filosofa com o martelo. Trad. Paulo César de Souza. São Paulo: Companhia das Letras, 2005, p. 122-123.

${ }^{234}$ NUNES, B. Ensaios filosóficos. São Paulo: Editora WMF Martins Fontes, 2010, p. 27.

${ }^{235}$ JASPERS, K. Introdução ao pensamento filosófico. Trad. Leônidas Hegenberg e Octanny Silveira da Mota. São Paulo: Cultrix, 1965, p. 141.
} 
do mundo, sem desprezar aqueles que já o trazem consigo. Até porque, existem múltiplos caminhos $^{236}$ para estruturarmos o pensamento filosófico, mostrou-nos já Karl Jaspers ${ }^{237}$, além daqueles delineados pelos Parâmetros Curriculares Nacionais ${ }^{238}$, e muitas vezes "disciplinar inteiramente o pensamento, sejam quais forem os termos como isso se exprima, pode corresponder a fechar os caminhos que permitem recombinações suscetíveis de conduzir o pensamento por caminhos inéditos". 239

Muitas objeções sofre o ensino da Filosofia em um Cursinho pré-vestibular e de várias frentes. Por parte dos alunos, que a princípio não veem sentido em dispender de um tempo já escasso estudando uma disciplina que cai de modo "indireto" no vestibular, em detrimento daquelas de incidência maior e mais óbvia: matemática, física, biologia, história, geografia. Por parte da Coordenação do Cursinho, que muitas vezes, premida pela necessidade conteúdista reclamada pelos vestibulares reduz a carga horária de matérias como Sociologia, Filosofia, Atualidades. Delineando-se uma verdadeira arena "onde se joga o jogo da significação e da representação, o currículo é, assim, objeto de uma disputa vital". ${ }^{240}$

Arroyo observa:

[...] reconstruir currículos exige incorporar o conhecimento das relações sociais de trabalho e dos padrões históricos, sociais, políticos, econômicos a que foi e continua atrelado o Ensino Médio. Uma autoimagem meritocrática do Ensino Médio reproduz o lugar inferior que foi demarcado para os coletivos populares, para os trabalhadores nas relações de classe e nesses padrões classistas, racistas, sexistas de poder, de trabalho e de conhecimento. ${ }^{241}$

Nasce aqui mais uma das antinomias que marca a educação no pré-vestibular popular: gerir um currículo que minimamente prepare o educando para o que lhe será cobrado no

\footnotetext{
${ }^{236}$ Essa multiplicidade não é prerrogativa unicamente da Filosofia, mas do processo cognitivo como um todo, haja vista a existência de "múltiplos sistemas de memória, espalhados por diferentes áreas cerebrais, com conexões e vias que podem interconectá-las em distintos meios, variando até mesmo de indivíduo para indivíduo". In: ESLINGER, P. J. Desenvolvimento do cérebro e aprendizado. Cérebro \& Mente, Campinas, 2003. Disponível em: $<\mathrm{http} / /$ www.cerebromente.org.br/n17/mente/braindevelopment_p.htm>. Acesso em 22 de maio 2018. ${ }^{237}$ JASPERS, Op. Cit., 1965, p. 44.

${ }^{238}$ A esse tocante, aludo à CERLETTI, em brilhante análise sobre o currículo em Filosofia: "Quando se estabelece um programa curricular, pressupõe-se uma espécie de aluno "médio", ao qual o programa estaria dirigido. Essa construção pedagógico-ideológica é uma ficção que torna invisíveis as origens culturais, o pertencimento à classe social, as distinções de gênero, etc". In: CERLETTI, A. O ensino de filosofia como problema filosófico. Trad. Ingrid Müller Xavier. Belo Horizonte: Autêntica Editora, 2009, p. 79.

${ }^{239}$ DANTAS, H. A infância da razão. São Paulo: Manole, 1990, p. 76.

${ }^{240}$ SILVA, T. T da. O currículo como fetiche: a poética e a política do texto curricular. Belo Horizonte: Autêntica, 2006, p. 65.

${ }^{241}$ ARROYO, Op. Cit., 2014, p. 168.
} 
vestibular, sem abrir mão de lhe criar um território formativo com outras possibilidades de reinventar conteúdos, de pensar outras possibilidades de agir, de pensar, de viver a cultura, a autonomia e a liberdade.

De acordo com Corti e Souza ${ }^{242}$, em pesquisa quantitativa sobre o ensino médio, a preparação para o ingresso no ensino superior, percepção de $43 \%$ dos alunos, foi destacadamente o fator mais relevante para eles durante o transcurso das séries do ensino médio.

\begin{tabular}{|c|c|c|c|c|}
\hline Prioridades & $\begin{array}{c}\mathbf{\%} \mathbf{1}^{\circ} \text { Ano } \\
\mathbf{3 5 5} \\
\text { alunos) }\end{array}$ & $\begin{array}{c}\mathbf{\%} \mathbf{2}^{\circ} \text { Ano } \\
\mathbf{( 2 9 6} \\
\text { alunos })\end{array}$ & $\begin{array}{c}\mathbf{\% ~ 3}^{\circ} \text { Ano } \\
(\mathbf{2 2 9} \\
\text { alunos })\end{array}$ & $\begin{array}{c}\% \text { Total } \\
\mathbf{8 8 0} \\
\text { alunos })\end{array}$ \\
\hline Formar o jovem para entrar na faculdade & 38 & 44 & 51 & 43 \\
\hline Formar o jovem para o mercado de trabalho & 34 & 32 & 28 & 32 \\
\hline Desenvolver o jovem como ser humano e cidadão & 23 & 18 & 15 & 19 \\
\hline Outros & 5 & 6 & 6 & 6 \\
\hline Total & $\mathbf{1 0 0}$ & $\mathbf{1 0 0}$ & $\mathbf{1 0 0}$ & $\mathbf{1 0 0}$ \\
\hline
\end{tabular}

Gráfico 17 - Prioridade do ensino médio, por série (\%)

Fonte: Corti e Souza (2008, p. 49)

Pensamos que as escolhas didáticas precisam ser empolgantes, mais do que isso, "é preciso que o problema formulado tenha uma significação para o estudante, de modo a conscientiza-lo de que a sua solução exige um conhecimento que, para ele, é inédito" ${ }^{243}$, de nada adianta repassarmos em uma aula de quarenta minutos de duração, oferecida a cada quinze dias, o conteúdo de três anos de ensino médio. Conteúdo que muitas vezes já não tinha instigado o aluno da primeira vez que fora apresentado. O resultado é ansiedade, desinteresse ${ }^{244}$,

\footnotetext{
${ }^{242}$ CORTI, A. P.; SOUZA, R. Que ensino médio queremos? Pesquisa quantitativa e grupos de diálogo sobre o ensino médio. São Paulo: Ação Educativa, 2008, p. 49.

${ }^{243}$ DELIZOICOV, D. Problemas e problematizações. In: PIETROCOLA, M. (Org.). Ensino de Física: conteúdo, metodologia e epistemologia numa concepção integradora. Florianópolis: Ed. da UFSC, 2001, p. 133.

${ }^{244}$ Gelamo conta-nos sobre essa experiência: "Os alunos, logo de início e de modo geral, não tinham o desejo de aprender os conteúdos 'fillosóficos'. Alguns, por terem passado por situações escolares não muito agradáveis com professores de Filosofia; outros por mero descaso ou preconceito; outros, ainda por influência dos primeiros. O que fazia unânime era a questão, muitas vezes marcada pelo silêncio dos rostos apáticos: 'o que isso (filosofia) tem a ver com o curso que eu faço?' A partir daí, a questão que eu passei a me colocar era: qual a importância em ensinar Filosofia a esses alunos, a importância de eles aprenderem, e a relação existente entre a Filosofia e os campos de saber específicos em cada um deles estava sendo formado?". In: GELAMO, R. P. O ensino de filosofia no limiar da contemporaneidade: o que faz o filósofo quando seu ofício é ser professor de filosofia? Marília, 2009. Tese (Doutorado em Educação) - Faculdade de Filosofia e Ciências, Universidade Estadual Paulista, p. 21.
} 
associações negativas à matéria, evasão: na melhor definição de Deleuze: o "logos se quebra em hieróglifos". ${ }^{245}$

Claro é:

[..] para além de uma ou de outra corrente filosófica, para além deste ou daquele filósofo em particular, mais importante e necessário é aprender com todos eles a tecer as críticas às verdades estabelecidas. Às verdades hegemônicas que, geralmente, provém de um grupo dominante e falam em nome e em defesa do poder das classes dominantes. Com objetivos explícitos ou implícitos manter a ordem das coisas e das relações de dominação de uns grupos sobre outros. O mais importante e necessário é perceber a dominação e lutar contra ela. Para tanto é necessário conhecer e reconhecer os instrumentos, aparelhos e estratégias que são usados para dominar. ${ }^{246}$ (ênfase nossa)

E não só:

A escola deve contribuir para tornar visível o que o olhar normatizador oculta. Deve ajudar a interrogar, a questionar, a compreender os fatores que historicamente contribuíram na produção da barbárie que supõe negar os mais elementares direitos humanos e sociais às grandes maiorias. A escola democrática deve ser um espaço capaz de nomear aquilo que, por si mesmo, não diz seu nome, que se disfarça nos grotescos eufemismos do discurso light, cortês, anoréxico. (ênfase nossa) ${ }^{247}$

Nestes termos, temos o grande desafio da pedagogia filosófica do Cursinho:

[...] em que medida se poderia ser um pouco filósofo, sem importar o nível de conhecimentos? É possível que, no ensino de filosofia em qualquer nível, haja algo próprio de o filosófico, algo que seja comum tanto àquele que se inicia na filosofia quanto ao filósofo experiente? ${ }^{248}$

${ }^{245}$ Cf. DELEUZE, G. Diferença e Repetição. $2^{\mathrm{a}}$ ed. Rio de Janeiro: Graal, 2006, p. 143.

${ }^{246}$ BRASIL, D. P. Antropologia e educação: raízes contraculturais do pensamento pedagógico de Rubem Alves. São Paulo, 2013. Tese (Doutorado em Educação) - Faculdade de Educação, Universidade de São Paulo, p. 174.

${ }^{247}$ GENTILI, P. Educar na esperança em tempos de desencanto. $7^{\mathrm{a}}$ ed. Petrópolis: Vozes, 2007, p. 42.

${ }^{248}$ CERLETTI, Op. Cit., 2009, p. 28. 


\subsubsection{A Filosofia ao rés do chão}

Sempre achei Filosofia chata e desinteressante. Mas aqui, parece até que é outra matéria!

Emily Tauany Souza Andrade Pereira, 16 anos, aluna do CPFF desde março de 2018

... na escola pública onde estudei a maioria dos professores e professoras eram muito descrentes, falavam frases de desânimo, olhavam para nós como se não fossemos capazes de muita coisa. E aqueles professores e professoras que davam aulas em escolas particulares sempre nos comparavam e diziam o quanto os alunos das escolas particulares eram mais educados.

Aluna do Cursinho NCN - Núcleo de Consciência Negra

É aflitivo notar como a Filosofia, uma arte eminentemente oral, arejada pela vida da pólis no tempo antigo, perde na modernidade essa característica, principalmente nas salas de aula. Do mesmo modo, não há nada mais anti-filosófico e anti-dialético do que o tom monocórdio de aulas de Filosofia que a reduzem à história da filosofia.

Pensamos que uma abordagem interessante é a referenciada por Gallo: a sala de aula como uma oficina, "[...] um local onde os conceitos historicamente criados são experimentados, testados, desmontados, remontados, sempre frente a nossos problemas vividos." ${ }^{249}$, em resumo, um convite a uma experiência de pensamento, que terá, às vezes, "algo de aleatório" 250 , se assumirmos que o "pensar implica novidade [...] e escapa ao controle da simples transmissão de um saber". 251

"Esse traço do ensino de filosofia não deve ser tomado como uma debilidade pedagógica, mas, pelo contrário, como uma fortaleza filosófica, já que constitui o momento em que, a partir da emergência de algo diferente, pode-se quebrar a repetição do mesmo" "252, todavia, “[...] muitos professores se perturbam com as implicações políticas de uma educação

\footnotetext{
${ }^{249}$ GALLO, S. A função da filosofia na escola e seu caráter interdisciplinar. Revista Sul Americana de Filosofia e Educação, [s.1.], n. 2, 2004. Disponível em: $<$ http://periodicos.unb.br/index.php/resafe/article/view/5426/4525>. Acesso em 28 ago. 2017.

${ }^{250}$ CERLETTI, Op. Cit., 2009, p. 38.

${ }^{251}$ Ibid., p. 39.

${ }^{252}$ Ibid., p. 81.
} 
multicultural, pois tem medo de perder o controle da turma caso não haja um modo único de abordar um tema, mas sim modos múltiplos e referencias múltiplas". 253

O ensino de Filosofia, já se viu, "não é algo que se possa resolver" 254 , bem assim, a análise de Gallo, acerca de Diferença e Repetição de Deleuze, mostra-nos que "o pensamento não é "natural" no ser humano, mas que é forçado sempre por um problema. Pensamos quando nos encontramos com um problema, com algo que nos força a pensar. E aprendemos quando pensamos" 255 , precisa ser provocado.

Assim, animados pela confiança de que "[...] sob certas condições qualquer um poderia vir a filosofar. Isso é, qualquer pessoa poderia fazer-se certo tipo de perguntas filosóficas e tentar, em alguma medida, responde-las"256, buscamos levar para as aulas atividades com problemas filosóficos escondidos para desafiar esse "nascer das ideias" ${ }^{257}$ e incitar o diálogo. 258

Importante destacar que não são exclusivamente textos da tradição filosófica, acreditamos firmemente no entrecruzamento das várias áreas do conhecimento como criador de outras formas de representação no mundo. Formas mais livres. Pensamos por fim, que se o professor souber montar uma "história", uma narrativa mesmo, daquele tema que quer problematizar vai interessar o aluno.

À exemplo de tais atividades cito: o ensaio "Como nasce a Superstição" 259 , do filósofo racionalista Baruch Espinosa; O Problema do Vagão do Trem ${ }^{260}$, delineado em 1967 pela

${ }^{253}$ HOOKS, Op. Cit., 2013, p. 51.

${ }^{254}$ CERLETTI, Op. Cit., 2009, p. 29.

${ }^{255}$ GALLO, S. As múltiplas dimensões do aprender. In: CONGRESSO DE EDUCAÇÃO BÁSICA COEB: aprendizagem e currículo. Anais... Florianópolis: COEB, 2012. Disponível em: $<$ http://www.pmf.sc.gov.br/arquivos/arquivos/pdf/13_02_2012_10.54.50>. Acesso em: 14 de maio 2018, p. 4.

${ }^{256}$ CERLETTI, Op. Cit., 2009, p. 28.

${ }^{257}$ Aludo aqui à maiêutica socrática ( $\left.\mu \alpha \iota \varepsilon v \tau \iota\right)$, literalmente, o "partejar das idéias". In: ABBAGNANO, N. Dicionário de Filosofia. Trad. Alfredo Bosi. Ed. rev. e amp. São Paulo: Martins Fontes, 2007, p. 734. ${ }^{258}$ Lembramos de Miguel Zabalza: "aprender é como conversar: recriamos nosso próprio discurso a medida em que interagimos com o discurso alheio", cf. ZABALZA, M. Os alunos universitários. In: $O$ ensino universitário, seu cenário e seus protagonistas. Trad. Ernani Rosa. Porto Alegre: Artmed, 2004, p. 38.

${ }^{259}$ No ensaio citado, Espinosa analisa o medo, como causa da superstição, utiliza o exemplo de Alexandre o Grande, cujo gênio oscilava entre coragem e temores durante suas campanhas e explora também o viés da superstição na Política.

${ }^{260} \mathrm{O}$ problema do vagão do trem propõe um cenário no qual um vagão descarrilhado dirige-se a toda velocidade em direção a cinco homens, que trabalhavam nos trilhos. Acionando uma alavanca hipotética, você poderia fazer com que o vagão passe a outro trilho, no qual se encontra somente uma pessoa. Trata-se de uma critica ao utilitarismo filosófico, visão pela qual, a ação moralmente correta será aquela que produzir as melhores consequências finais. Há também possibilidade de incluirmos componentes morais e éticos no problema: "se a pessoa do outro trilho for sua mãe? Quem você 
filósofa Philippa Foot e, posteriormente pela filósofa Judith Jarvis Thomson, uma simulação do Julgamento de Sócrates, inspirado pela obra de I. F. Stone ${ }^{261}$, uma simulação do Julgamento dos Exploradores de Cavernas ${ }^{262}$, teorizado pelo filósofo do Direito Lon L. Fuller, o Paradoxo do Navio de Teseu ${ }^{263}$, proposto inicialmente por Plutarco e revisitado por Thomas Hobbes ${ }^{264} \mathrm{e}$ Gottfried Leibniz ${ }^{265}$, a peça Os Físicos de Friedrich Dürrenmatt. ${ }^{266}$

A metodologia consiste em levar no dia da aula os textos impressos, os quais são distribuídos a cada um dos alunos para que sigam a leitura que faremos juntos. Peço para que diferentes alunos leiam em voz alta enquanto acompanho fazendo alguma interrupção ou comentário pontual. A leitura feita por eles próprios evita que se dispersem em outras atividades e pensamentos, o que é comum acontecer em casos de transmissão de informações verbais por longos períodos por apenas uma pessoa.

Ao final da leitura, começamos as intervenções. Durante os anos de ensino no Cursinho, percebemos ser ineficaz enviar a eles o material por e-mail ou com antecedência de um encontro a outro, isso porque se enviado no suporte digital, poucos conseguem abrir, imprimir e leva-lo para a aula, seja por falta de meios para impressão, preguiça ou esquecimento.

escolheria? Se os cinco homens do primeiro trilho forem cinco estupradores? ainda assim, deveriam ser salvos?".

${ }^{261}$ A defesa de Sócrates, no auge de seus 70 anos, por volta de 400 a.C perante o Tribunal de Atenas por ter corrompido a juventude ateniense é um dos textos filosóficos com maior abertura para questionamentos filosóficos.

${ }^{262}$ Referida obra, em que pese utilizada majoritariamente nos cursos de bacharelado em Direito, vai além da mera interpretação sobre o dilema clássico entre Direito natural e Positivismo jurídico. Com ela conseguimos problematizar com os alunos por que muitas vezes a lei e o próprio sistema jurídico não revelam-se instrumentos efetivos de Justiça. Os alunos identificam em seu cotidiano cenas e microestruturas em que tiveram o sentido da lei voltados contra si ou seus interesses, casos em que houve uma prestação jurisdicional, mas não Justiça e mostram-se muitíssimo envolvidos. O enredo, extremamente envolvente, traz-nos uma situação em que exploradores de uma sociedade espeleológica envolvem-se em um acidente que os deixa confinados por quarenta dias em uma caverna, obrigando-os, no $33^{\circ}$ do aprisionamento, a matar um dos colegas para se alimentar. Processados, são levados a julgamento, onde quatro juízes pronunciam suas decisões, uns baseando-se no bom senso e no estado de natureza, outros, pautando-se pelo legalismo extremo.

${ }^{263} \mathrm{O}$ paradoxo do Navio de Teseu traz-nos uma discussão filosófica acerca de identidade, essência e a fugacidade dos elementos da physis. Um navio "A" parte para uma longa viagem, durante a qual, são trocadas partes de madeira do navio e peças de sua estrutura original, chegando ao porto, anos depois totalmente reconstruído (navio "B"). Com as partes descartadas, constrói-se paralelamente uma outra embarcação "C". Qual é o navio original de Teseu? O que faz do Navio de Teseu o Navio de Teseu? As peças? O fato dele estar tripulado por Teseu?

${ }^{264}$ FINN, S. J. Thomas Hobbes and the Politics of Natural Philosophy. Nova Iorque: Continuum International Publishing Group, 2006, p. 42.

${ }^{265}$ LEIBNIZ, G. Os Pensadores. Trad. L. J. Baraúna. São Paulo: Abril Cultural, 1980, p. 173.

${ }^{266} \mathrm{O}$ enredo de Os Físicos, publicado em 1962, além de brilhante, suscita grandes possibilidades de exercício filosófico. Trata-se de uma alegoria da patologia do poder e a culpa pelo saber científico. 
Da mesma forma, verificamos a importância de cada um receber o material individualizado, pois denota que houve uma atenção prévia para com eles. A aula foi pensada, a professora dedicou um tempo a preparar o material. Além da vantagem adicional, a qual estimulamos fortemente, de que escrevam suas próprias reflexões à margem dos textos.

Os júris simulados (Aulas do Caso dos Exploradores de Cavernas e Julgamento de Sócrates) estão entre as atividades que mais arrebatam nossos alunos, preferência que se explica, talvez, pela novidade que representam, pela dinamicidade da aula e envolvimento mais visceral nas questões. Raramente são chamados nas aulas regulares a dar sua contribuição acerca do que está sendo ensinado, e menos ainda, a treinar a precisão argumentativa, a clareza e lógica formal, habilidades que se requer num júri. A aluna Evelyn Cristine Maximo Alves, 17 anos, ressalta como fator primordial para seu aprendizado justamente essa possibilidade do diálogo: “A liberdade de expressão, poder falar com a professora sobre os assuntos ensinados com simplicidade, é o que eu acho fundamental". ${ }^{267}$

Proponho de início que dividam a sala entre acusação e defesa, conforme sua convicção e preparem suas teses, reforçando uma das posições escolhidas. Em um segundo momento, inverto, para que se exercitem justamente na defesa do ponto de vista contrário ao que acreditavam inicialmente, "rompendo com o objeto imediato e recusando a sedução da primeira escolha"268, como aponta-nos Bachelard em sua magistral Psicanálise do Fogo.

Sobre essa atividade, Everson Oliveira ${ }^{269}, 19$ anos, conta-nos

[...] o dia da aula do Julgamento da Caverna foi o melhor dia, assim, todos os dias são bons, mas esse dia foi muito massa. Eu nem achei que eu sabia defender um ponto de vista até o fim desse jeito, com todo mundo te atacando. Acho que filosofia é isso. ${ }^{270}$

Os depoimentos colhidos com os alunos de Filosofia no Cursinho dão-nos a ver como o estudante do Cursinho Popular entende e assimila o processo cognitivo da Filosofia. As entrevistas privilegiaram as seguintes variáveis: 1) Se o aluno já teve aulas de Filosofia em sua escola durante o ensino médio; 2) Quais as maiores dificuldades enfrentadas na compreensão

\footnotetext{
${ }^{267}$ ALVES, E. Entrevista concedida a Stella Verzolla Tangerino. São Paulo, 10 mar. 2018.

${ }^{268}$ BACHELARD, G. A psicanálise do fogo. Trad. Paulo Neves. $3^{\text {a }}$ ed. São Paulo: Martins Fontes, 2008, p. 1.

${ }^{269}$ OLIVEIRA, E. Entrevista concedida a Stella Verzolla Tangerino. São Paulo, 10 mar. 2018.

${ }^{270}$ Sobre essa assimilação do aluno, citamos "[...] A percepção de si mesmo no espaço coletivo a partir da legitimidade para habitar e participar, ser ouvido e considerado, permite a ascensão de outro modo de relação consigo mesmo e com o outro, que se apresenta a partir de uma concepção dialógica". In: SAFFIOTI, Op. Cit., 2008, p. 173.
} 
dessa matéria e 3) O que o aluno via como diferencial entre as aulas de Filosofia de sua escola regular e as do Florestan Fernandes. Reproduzimos abaixo, trechos das narrativas mais expressivas.

A totalidade dos alunos entrevistados respondeu ter tido aulas regulares de Filosofia durante o Ensino Médio, não sendo, portanto, as aulas do Cursinho o primeiro contato de nenhum deles com a disciplina. Como dificuldades apresentadas para o entendimento da Filosofia, figuraram: dificuldade na leitura e compreensão dos textos filosóficos, preguiça e falta de disposição para a leitura, a forma como o conteúdo é passado, o significado de alguns termos gregos/linguagem filosófica, a distância da matéria estudada com a realidade; conteúdo passado somente a partir de textos de apostila, tornando a aula desinteressante, pouca diversidade dos temas (sempre os mesmos filósofos, sem novidade).

Para a aluna Nicole Otuari, de 17 anos, a temática diversificada trazida às aulas é um dos maiores incentivos: "Minha professora da escola só fala sobre o Mito da Caverna [..] Sinto que nas aulas no CPFF a professora me faz pensar e questionar onde está a Filosofia no meu dia a dia, enquanto na escola eu só decoro o conteúdo"271. "Na escola, Filosofia é mais Ética e tempos antigos, e aqui no CPFF são vários temas diferentes" ${ }^{\text {272, }}$, conta-nos Deborah Espíndola Silva, de 16 anos.

Diogo Antonio da Silva, 17 anos, começou a frequentar o Cursinho em março de 2018, e sua impressão é bastante parecida com a da colega Nicole:

Na minha escola, a matéria de filosofia é apenas sobre Sócrates, Marx, eu sempre acabava evitando a filosofia por achar que era apenas isso [..] Em duas aulas de Filosofia do Florestan eu já tive mais interesse do que em três anos estudando Filosofia na escola. É a primeira vez que eu gosto de Filosofia! ${ }^{273}$

Também em face da pouca diversidade dos temas, a aluna Geovanna Oliveira Barbosa, de 16 anos, em entrevista a nós concedida descreve: "O conteúdo da escola desde o primeiro ano é basicamente a mesma coisa, falando sempre dos mesmos filósofos, já no Cursinho a professora já falou de filósofos que eu não conhecia e explicou de uma maneira diferente e bem fácil". ${ }^{274}$

\footnotetext{
${ }^{271}$ OTUARI, Nicole. Entrevista concedida a Stella Verzolla Tangerino. São Paulo, 10 mar. 2018. ${ }^{272}$ SILVA, D. Entrevista concedida a Stella Verzolla Tangerino. São Paulo, 10 mar. 2018.

${ }^{273}$ DA SILVA, Diego Antônio. Entrevista concedida a Stella Verzolla Tangerino. São Paulo, 10 mar. 2018.

${ }^{274}$ BARBOSA, G. O. Entrevista concedida a Stella Verzolla Tangerino. São Paulo, 10 mar. 2018.
} 
Agraine Esteves, 28 anos, entrou no Florestan em maio de 2018 e conta-nos que até então nunca havia gostado de Filosofia:

Quando eu comecei a estudar eu até me perguntava como podia existir uma matéria em que eu não soubesse nada e com o cursinho eu comecei a ouvir, a questionar e passei a me interessar por esta disciplina, devido assim, a ela fazer você pensar, refletir sobre a sociedade e ver a vida, a sociedade por um contexto muito mais amplo, como os pensamentos do filósofo Michel Foucault que a professora apresentou. Eu vi que sempre existirá dois lados da história, se existe uma sociedade oprimida é porque existe um governo opressor. Existe uma guerra pelo poder que nos atinge até hoje. Então, precisamos pensar filosoficamente para entender a sociedade e até a nossa maneira de pensar. ${ }^{275}$

Cícera Heloísa, 18 anos, comenta que "As aulas do CPFF faz a gente pensar e ter até uma crise existencial porque vemos o que tem por trás de muita coisa na sociedade, enquanto as aulas da minha escola eram muito fora da realidade". ${ }^{276}$

A aluna Ana Carolina Sarain, de 16 anos, relata que em sua escola a maior dificuldade era relacionar o conteúdo estudado com sua aplicação no dia-a-dia, conta-nos: "A filosofia na escola nos explica o jeito de pensar de Platão e Sócrates, mas as daqui nos mostram várias formas de pensar e como aplicar o que falamos nos dias atuais". ${ }^{277}$

Na mesma linha, as palavras de Thaise Cristina Santos Moroni, 17 anos: "Estou me interessando muito nessa matéria e me questionando mais sobre coisas que acontecem no meu cotidiano"278. "Eu gosto dessas metáforas, porque consigo pensar na Filosofia relacionada com a nossa vida" ${ }^{279}$, diz Amanda Guimarães, também de 17 anos de idade.

Marcus Vinícius Carvalho de Lima, 17 anos, afirma que o maior ganho, para ele, foi sua mudança de visão sobre as coisas: “[...] Eu julgava muito até conhecer a Filosofia do Cursinho e isso mudou meu pensamento. A maior diferença que eu vejo, é que na minha escola a professora que é paga pra dar aula não dá e aqui onde a professora não é paga a aula é $100 \%$. É muito louco isso". ${ }^{280}$

\footnotetext{
${ }^{275}$ ESTEVES, A. Entrevista concedida a Stella Verzolla Tangerino. São Paulo, 2 jun. 2018.

${ }^{276}$ HELOÍSA, C. Entrevista concedida a Stella Verzolla Tangerino. São Paulo, 2 jun. 2018.

${ }^{277}$ SARAIN, A. C. Entrevista concedida a Stella Verzolla Tangerino. São Paulo, 10 mar. 2018.

${ }^{278}$ MORONI, T. C. S. Entrevista concedida a Stella Verzolla Tangerino. São Paulo, 10 mar. 2018.

${ }^{279}$ GUIMARÃES, A. Entrevista concedida a Stella Verzolla Tangerino. São Paulo, 10 mar. 2018.

${ }^{280}$ LIMA, M. V. C. Entrevista concedida a Stella Verzolla Tangerino. São Paulo, 10 mar. 2018.
} 
"Na escola é tudo robotizado", diz Nicole Oliveira, 17 anos: [...] "a aula não fluía e os professores parece que fazem questão de não deixar a aula interessante. No CPFF, em uma aula abordamos mais de um assunto nas aulas. Não é massivo aprender e é divertido". ${ }^{281}$

As entrevistas espelham como "[...] na sala de aula, muitas vezes, as discussões se apoiam em argumentos fundamentados na autoridade e não em justificativas ou evidências: é assim porque os cientistas estudaram ou isso é certo porque está no livro" ${ }^{282}$, e que é possível conseguirmos a adesão e atenção dos educandos ressignificando a visão da matéria pelo confronto de olhares, pelo enfrentamento analítico de problemas filosóficos mas também dando-lhes espaço para o exercício da autonomia e para assimilação do que foi construído em aula porque Filosofia faz-se, muitas vezes, no silêncio dessas pausas.

${ }^{281}$ OLIVEIRA, N. Entrevista concedida a Stella Verzolla Tangerino. São Paulo, 2 jun. 2018.

${ }^{282}$ MARANDINO, M. Ciência, tecnologia e educação promovendo a alfabetização científica de jovens cidadãos. In: DAYRELL; CARRANO; LINHARES, Op. Cit., 2014, p. 279. 


\section{CONSIDERAÇÕES FINAIS}

Não era a sensação de uma batalha ganha, de uma luta em que os obstáculos foram vencidos. Muito mais do que isso, era o prazer interior de ter realizado algo que tanto desejei, de ter feito e visto o que fiz e vi. O profundo prazer de poder resumir minha maior viagem num simples círculo sobre o papel. ${ }^{283}$

Amyr Klink

O percurso de nossa produção teórica, a despeito do paradoxo que a própria questão da existência dos Cursinhos Preparatórios Populares encerra, mostrou-nos, a originalidade de um projeto que tenta lançar-se para além de "discursos e práticas que oscilam basicamente entre a sobrevivência e a adaptação" 284 e dar o aporte a um dos primeiros Direitos do ser humano: "saber-se no mundo, nas letras, nas ciências, nas artes"285, mostrar outras possibilidades.

Enquanto relato sistematizado de uma pratica e de uma vivencia pedagógica que abrese à ativação de um espaço educacional alternativo, que é também possibilidade de legitimação de leituras futuras para construção coletiva de enfrentamento aos "projetos educacionais estatais que não representavam os interesses populares, ou que até se encaminhavam para negá-los"286, buscamos mostrar como ações concretas voltadas para a transformação social articulam-se no espaço urbano da capital paulista contra a exclusão e invisibilidade.

As narrativas colhidas foram indicativas de que mais do que um movimento direcionado à aprovação nos vestibulares, os Cursinhos, notadamente o caso relatado, trabalham com a abertura de horizontes e consciência de auto identidade dos alunos, com o resgate do compromisso político por parte dos professores e com outras expressões subjetivas do direito à educação, em um "processo de criação e recriação do conhecimento que parte de uma teoria dialética do conhecimento, pois parte da prática, teoriza sobre ela e volta para a prática para transformá-la". ${ }^{287}$

\footnotetext{
${ }^{283}$ KLINK, A. Paratii - entre dois polos. São Paulo: Companhia das Letras, 1992.

${ }^{284}$ STRECK, D. R. A educação popular e a (re) construção do público. Há fogo sob as brasas? Revista Brasileira de Educação, Rio de Janeiro, v. 11 n. 32, 2006, p. 272.

${ }^{285}$ ARROYO, M. Repensar o ensino médio: por quê? In: DAYRELL; CARRANO; LINHARES, Op. Cit., 2014, p. 72.

${ }^{286}$ GRACIANI, M. S. S. Pedagogia social de rua: análise de uma experiência vivida. $6^{\mathrm{a}}$ ed. São Paulo: Cortez, Instituto Paulo Freire, 2009. Coleção Perspectiva, v. 4, p. 47.

${ }^{287}$ GRACIANI, M. S. S. Desafios metodológicos da prática social transformadora ou teorizar a prática social para transformá-la. In: SILVA, R. da. et al. (org.). Pedagogia Social: contribuições para uma teoria geral da Educação Social. v. 2. São Paulo: Expressão e Arte, 2011. p. 292.
} 
Em um segundo movimento da análise, decorrência direta de nossa prática docente de seis anos no Florestan Fernandes, buscou-se pensar que referentes poderiam orientar uma ação criativa do professor de um coletivo popular pré-vestibular, especificamente em relação ao ensino da Filosofia, face à diversidade de formação, realidade sócio-econômica e vivência de seus educandos.

Toda a literatura e percepção prática do problema deu-nos a ver que mais pedagógico do que pensar um currículo estruturado em resolver defasagens e ausências do Ensino Médio, é posicionar o aluno como um interlocutor válido no protagonismo do debate filosófico, trazendo-lhe textos e atividades que resgatem a curiosidade e a empolgação perdidas no correr dos anos escolares, sem as quais não se constrói qualquer possibilidade de mudança do olhar, pré-requisito de toda atividade filosófica. ${ }^{288}$

Para nós, a Filosofia é uma das coisas mais essenciais na vida, ela traz um profundo sentido humanizador: "vê-la, senti-la, apropriar-se dela nos deixa mais humanos" 289 e é muito intenso ver os alunos frequentando-a, fazendo outras leituras de possibilidades, discutindo a partir de conceitos abstratos.

O Curso de formação de educadores promovido pela Rede Emancipa em uma tarde de 2013 na Escola Municipal Derville Alegretti, zona norte de São Paulo, meses antes do início do ano letivo, lembrava a nós, futuros professores, que a meta dos cursinhos populares a longo prazo seria deixar de existir. Fosse porque no futuro não mais precisaríamos "remediar" deficiências educacionais de um sistema precarizado na base, fosse porque o vestibular teria contornos mais democráticos de seleção ou até, na voz dos mais otimistas, seria eliminado. A experiência trazida pela pesquisa que ora se encerra nos faz divergir dessa leitura.

Pensamos que equacionada a dinâmica educacional que lhe deu origem, o cursinho pode representar o prenúncio para outras formas de associação que simplesmente compartilhe as expressões humanas artísticas e criativas tão ricas e que hoje já se fazem presentes, mas nos poucos espaços entre as aulas e que tanto empolgam alunos e educadores: saraus literários, sessões de filmes, aulas de dança, visitas a exposições pela cidade. "Cultura se ensina e se aprende" 290 e nos faz mais justos, mais fecundos e mais humanos.

\footnotetext{
${ }^{288}$ Merleau Ponty explica-nos sobre esse olhar filosófico: “[...] Em outros termos: é a visão que vê mais do que se vê; é a visão que vê o mundo primordial, que vê as coisas como que pela primeira vez". In: $O$ olho e o espírito. São Paulo: Cosac \& Naify, 2004, p. 42.

${ }^{289}$ PINSKI, J. Por que gostamos de história. São Paulo: Contexto, 2013, p. 68.

${ }^{290}$ Ibid., 2013, p. 124.
} 
Assim, a potência do estudo que apresentamos, cremos, é análoga à certeza de que "em face das estruturas do presente injusto, o justo não se apresenta como uma decorrência nem automática nem necessária. Mas também não é uma impossibilidade". ${ }^{291}$

${ }^{291}$ MASCARO, A. L. Filosofia do Direito. $5^{\text {a }}$ ed. rev. e amp. São Paulo: Atlas, 2016, p. 593. 


\section{REFERÊNCIAS BIBLIOGRÁFICAS}

ABBAGNANO, Nicola. Dicionário de Filosofia. Trad. Alfredo Bosi. Ed. rev. e amp. São Paulo: Martins Fontes, 2007.

ADORNO, Sérgio.; NUNES, Camila Dias.; NERY, Marcelo Batista. A cidade e a dinâmica da violência. In: KOWARICK, L.; FRUGOLI JR., H. (org.). Pluralidade urbana em São Paulo: vulnerabilidade, marginalidade, ativismos". São Paulo: Editora 34; FAPESP, 2016.

AGIER, Michel. Antropologia da cidade: lugares, situações, movimentos. São Paulo: Terceiro Nome, 2009.

ALBUQUERQUE JR, Durval M de. História: a arte de inventar o passado. Ensaios de teoria da História. Bauru, SP: Edusc, 2007.

ALVES, Rubem. Livro sem fim. São Paulo: Editora Loyola, 2002.

AMADO, João (org.). Manual de investigação qualitativa em educação. Portugal: Universidade de Coimbra, 2014.

ANDRÉ, Marli Eliza Dalmazo Afonso. Estudo de caso em pesquisa e avaliação educacional. Brasília: Editora Liber Livros, 2008. Série Pesquisa, v. 13, p. 17.

CARVAlHO, José Carmelo Braz de.; ALVIM FILHO, Hélcio.; COSTA, Renato Pontes (Orgs.). Cursos Pré-vestibulares Comunitários: espaços de mediação pedagógica. Rio de Janeiro: PUC-Rio, 2005.

ARELARO, Lisete Regina Gomes; CUNHA, Gilberto (orgs). Às portas da universidade: alternativas de acesso ao ensino superior. São Paulo: Xamã, 2012.

ARROYO, Miguel G. Outros Sujeitos, Outras Pedagogias. Petrópolis, RJ: Vozes, 2012.

AUSUBEL, David Paul; NOVAK, Joseph; HANESIAN, Helen. Psicologia educacional. Rio de Janeiro: Editora Interamericana, 1980.

BACHELARD, Gaston. A psicanálise do fogo. Trad. Paulo Neves. $3^{\text {a }}$ ed. São Paulo: Martins Fontes, 2008.

BALANDIER, Georges. et al. Civilizações - Entrevistas do Le Monde. Trad. Sérgio Flaksman. São Paulo: Ática, 1989,

BARCA, Isabel. Educação Histórica: uma nova área de investigação. Revista da Faculdade de Letras História, Porto, v. 2, n. 3, 2001.

BATISTA, Maria do Socorro Xavier. Educação popular em movimentos sociais: construção coletiva de concepções e práticas educativas emancipatórias. In: $28^{a}$ REUNIÃO NACIONAL DA ANPED, 2005, Caxambu. Anais...Caxambu: ANPED, 2005.

BHABHA, Homi K. O local da cultura. Belo Horizonte: UFMG, 1998. 
BEISIEGEL, Celso de Rui. Politica e Educação Popular: a teoria e a prática de Paulo Freire no Brasil. Brasília: Liber, 2008.

BENEVIDES, Maria Victória. A cidadania ativa: referendo, plebiscito e iniciativa popular. São Paulo: Ática, 1991.

BENJAMIN, Walter. Charles Baudelaire: um lírico no auge do capitalismo. São Paulo: Brasiliense, 1989. Obras Escolhidas, v. 3.

BOBBIO, Norberto. A era dos direitos. Trad. Carlos Nelson Coutinho. Rio de Janeiro: Elsevier, 2004.

BOGDAN, Robert. C.; BIKLEN, Sari. K. Investigação qualitativa em educação. Porto: Porto, 1994.

BONAVIDES, Paulo. Curso de Direito Constitucional. $8^{\text {a }}$ ed. São Paulo: Malheiros Editores, 1999.

BORDIEU, Pierre. Escritos de Educação. Petrópolis: Vozes, 2015.

. A miséria do mundo. Petrópolis/RJ: Vozes, 2007.

. O poder simbólico. Rio de Janeiro: Bertrand Brasil S.A, 1989.

BORGES, Ângela.; CARVALHO, Inaiá. Revistando os efeitos de lugar: segregação e acesso ao mercado de trabalho em uma metrópole brasileira. Cad. CRH, Salvador, 1, v. 30, n. 79, 2017. Disponível em: <http://dx.doi.org/10.1590/s0103-49792017000100008>. Acesso em 4 dez. 2017.

BOTELHO, Isaura. Os equipamentos culturais na cidade de São Paulo: um desafio para a gestão pública. Espaço e Debates, São Paulo, n. 43-44, 2004.

BRANDÃO, C. R. Revista de educação de adultos, México, v. 2, n. 2, 1984.

BRASIL, Dildo Pereira. Antropologia e educação: raízes contraculturais do pensamento pedagógico de Rubem Alves. São Paulo, 2013. Tese (Doutorado em Educação) - Faculdade de Educação, Universidade de São Paulo.

CALDEIRA, Teresa Pires do Rio. Cidade de Muros: crime, segregação e cidadania em São Paulo. São Paulo: Editora 34/EDUSP, 2000.

. Qual a novidade dos rolezinhos? Espaço público, desigualdade e mudança em São Paulo. Novos Estudos - Cebrap, São Paulo, n. 98, ano, p. 13.

CARLOS, Ana Fani Alessandri. O poder do corpo no espaço público: o urbano como privação e o direito à cidade. GEOUSP - Espaço e Tempo, São Paulo, v. 18, n. 2, 2014.

CASASSUS, Juan. A escola e a desigualdade. Brasília/DF: Plano Editora, 2002. 
CASTEL, Robert. As metamorfoses da questão social: uma crônica do sálario. Rio de Janeiro: Vozes, 1998.

CASTRO, Clóves Alexandre de. Cursinhos alternativos e populares: movimentos territoriais de luta pelo acesso ao ensino público superior no Brasil. Presidente Prudente, 2005. Dissertação (Mestrado em Geografia) - Faculdade de Ciências e Tecnologia da Universidade Estadual Paulista, Presidente Prudente.

CATELLI JR., Roberto (org.). Formação e pratica na educação de jovens a adultos. São Paulo: Ação Educativa, 2017.

CERLETTI, Alejandro. O ensino de filosofia como problema filosófico. Trad. Ingrid Müller Xavier. Belo Horizonte: Autêntica, 2009.

CHAVES, Taline. Cursinho popular - Abrindo as portas do universo: jovens da periferia e os acessos à educação e ao mundo do trabalho. São Paulo, 2013. Iniciação científica - Pontifícia Universidade Católica.

CHAUÍ, Marilena. Brasil: mito fundador e sociedade autoritária. São Paulo: Fundação Perseu Abramo, 2000.

n. 24, 2003.

. A universidade pública sob nova perspectiva. Rev. Bras. Educ., Rio de Janeiro,

CORAZZA, Sandra Mara. Nos tempos da educação: cenas de uma vida de professora. Revista da ABEM, Porto Alegre, v. 12, n. 7, 2005.

CORTI, Ana Paula; SOUZA, Raquel. Que ensino médio queremos? Pesquisa quantitativa e grupos de diálogo sobre o ensino médio. São Paulo: Ação Educativa, 2008.

CROCHÍK, José Leon. Os desafios atuais do estudo da psicologia na modernidade. Psicologia USP, São Paulo, v. 9, 1998.

COSTA, Otávio. Memória e paisagem: em busca do simbólico dos lugares. Espaço e Cultura, Rio de Janeiro, n. 15, 2003.

DANTAS, Heloysa. A infância da razão. São Paulo: Manole, 1990.

DAYRELL, Juarez.; CARRANO, Paulo.; LINHARES, Carla Maia (org.). Juventude e ensino médio: sujeitos e currículos em diálogo. Belo Horizonte: Editora UFMG, 2014.

DE CERTEAU, Michel de. A invenção do cotidiano: artes de fazer. Petrópolis: Vozes, 1994.

DELEUZE, Gilles. Diferença e Repetição. 2a ed. Rio de Janeiro: Graal, 2006.

DELIZOICOV, Demétrio. Problemas e problematizações. In: PIETROCOLA, M. (Org.). Ensino de Física: conteúdo, metodologia e epistemologia numa concepção integradora. Florianópolis: Ed. da UFSC, 2001. 
DI PIERRO, Maria Clara. Tradições e concepções de educação de jovens e adultos. In: CATELLI JR., R. (org.). Formação e pratica na educação de jovens a adultos. São Paulo: Ação Educativa, 2017.

ESLINGER, Paul J. (2003). Desenvolvimento do cérebro e aprendizado. Cérebro \& Mente, Campinas, 2003. Disponível em: $<$ http://www.cerebromente.org.br/n17/mente/braindevelopment_p.htm>. Acesso em 22 de maio 2018.

FACEIRA, Lobélia da Silva. O ProUni como política pública em suas instâncias macroestruturais, meso-institucionais e microssociais: pesquisa sobre a sua implementação pelo MEC e por duas universidades na região metropolitana do Rio. Rio de Janeiro, 2009. Tese (Doutorado em Educação) - Pontifícia Universidade Católica.

FANTIN et al. Feito a lápis: experiências de educação popular na universidade. Cadernos de Pesquisa, São Paulo, 2004.

FÁVERO, Osmar. Uma pedagogia da participação popular: análise da prática educativa do MEB (1961/1966). Campinas: Autores Associados, 2006.

FOUCAULT, Michel. Estratégia, Poder-Saber. Rio de Janeiro: Forense Universitária, 2006. Ditos e escritos IV.

FERNANDES, Renata. Cultura e transformação no contexto da educação não formal. Regulamento do Programa Rumos - Educação Cultura e Arte. São Paulo: Itaú Cultural, 2005. Documento disponível em <www.itaucultural.org.br/rumos>. Acesso em data abr. 2018.

FERREIRA, Bernardo. O risco do político: crítica ao liberalismo e teoria política no pensamento de Carl Schmitt. Belo Horizonte: Editora UFMG; Rio de Janeiro: IUPERJ, 2004.

FERREIRA, Ignez Costa Barbosa.; VASCONCELOS, Ana Maria Nogales.; PENNA, Nelba de Azevedo. Violência urbana: vulnerabilidade dos jovens da periferia das cidades. In: ENCONTRO NACIONAL DE ESTUDOS POPULACIONAIS, 16, 2008, Minas Gerais. Anais... Minas Gerais: Encontro Nacional de Estudos Populacionais, 2008.

FREIRE, Paulo. Pedagogia da autonomia. Rio de Janeiro: Paz e Terra, 2014.

. Pedagogia da indignação: cartas pedagógicas e outros escritos. São Paulo: Editora Unesp, 2000.

. Política e educação. São Paulo: Cortez, 1993.

. Pedagogia dos sonhos possíveis. São Paulo: Paz e Terra, 2014.

Coleção Leitura.

Educação como pratica da liberdade. $27^{\mathrm{a}}$ ed. São Paulo: Paz e Terra, 2003. . Conscientização: teoria e pratica da libertação: uma introdução ao pensamento de Paulo Freire. $4^{\mathrm{a}}$ ed. São Paulo: Moraes, 1980. 
FINN, Stephen J. Thomas Hobbes and the Politics of Natural Philosophy. Nova Iorque, Continuum International Publishing Group, 2006.

GADOTTI, Moacir. Boniteza de um sonho: ensinar-e-aprender com sentido. Novo Hamburgo: Feevale, 2003.

. História das idéias pedagógicas. São Paulo: Ática, 1993.

. Estado e Educação Popular - desafios de uma política nacional. Disponível em: <http://www.participa.br/articles/public/0006/3700/Estado_e_Educa\%C3\%A7\%C3\%A3o_Po pular_-_Gadotti.pdf>. Acesso em 21 jul. 2016.

. A escola na cidade que educa. Cadernos CENPEC, n. 1, 2006.

GALLO, Sílvio. Em torno de uma educação menor. Educação e Realidade, Porto Alegre, v. 27, n. 2, 2002.

- A função da filosofia na escola e seu caráter interdisciplinar. Revista SulAmericana de Filosofia e Educação, [s.l.], n. 2, 2004.

As múltiplas dimensões do aprender. In: CONGRESSO DE EDUCAÇÃO BÁSICA - COEB: aprendizagem e currículo. Anais... Florianópolis: COEB, 2012. Disponível em: <inserir link>. Acesso em: 14 maio 2018.

GELAMO, Rodrigo Pelloso. O ensino de filosofia no limiar da contemporaneidade: o que faz o filósofo quando seu ofício é ser professor de filosofia? Marília, 2009. Tese (Doutorado em Educação) - Faculdade de Filosofia e Ciências, Universidade Estadual Paulista.

GOHN, Maria da Glória. Teorias dos movimentos sociais: paradigmas clássicos e contemporâneos. São Paulo: Loyola, 1997.

GUATTARI, Felix; DELEUZE, Gilles. Anti-Édipo: Capitalismo e esquizofrenia. Trad. Joana Morais Varela e Manuel Maria Carrilho. Lisboa: Assírio Alvim,1972.

GENTILI, Pablo. Educar na esperança em tempos de desencanto. $7^{\mathrm{a}}$ ed. Petrópolis: Vozes, 2007.

GRACIANI, Maria Stela. Santos. Pedagogia social de rua: análise de uma experiência vivida. $6^{\text {a }}$ ed. São Paulo: Cortez, Instituto Paulo Freire, 2009. Coleção Perspectiva, v. 4.

GUTIÉRREZ, Francisco. Educação como práxis política. São Paulo: Summus, 1988.

HABERMAS, Jurgen. Arquitetura moderna e pós-moderna. Novos Estudos - CEBRAP, São Paulo, v. 8, n. 18, 1987.

. Que significa socialismo hoje? Revolução recuperadora e necessidade de revisão de esquerda. Novos Estudos - Cebrap, São Paulo, n. 30, 1991. 
HALL, Peter. The movement from keynesianism to monetarismo: institucional analysis and British economic policy in the 1970s. In: STEINMO, Sven.; THELEN, Kathleen.; LONGSTRETH, Frank. (org.). Structuring politics. Oxford: Cambridge University Press, 2010.

HARDT, Michel; NEGRI, Antônio. Multidão, guerra e democracia na era do Império. Rio de Janeiro: Record, 2005.

HARVEY, David. Los límites del capitalismo y la teoria marxista. México: Fondo de Cultura Económica, 1999.

HECHT, Yacov. Educação democrática: o começo de uma história. Trad. Adriana Scandolara. Belo Horizonte: Autêntica, 2016.

HEGEL, Georg Wilhelm. Vorlesungen über die geschichte der philosophie (Preleções sobre a história da filosofia). In: Sämtliche Werke, Jubiläumsausgabe, v. XVIII.

HOOKS, Bell. Ensinando a transgredir: a educação como pratica da liberdade. Trad. Marcelo Brandão Cipolla. São Paulo: Editora WMF Martins Fontes, 2013.

INOJOSA, Rose Marie. Redes de compromisso social. Revista de Administração Pública, Rio de Janeiro, v. 3, n. 5, 1999.

ISHAGHPOUR, Youssef; KIAROSTAMI, Abbas/ ISHAGHPOUR, Youssef. Abbas Kiarostami - Duas ou três coisas que eu sei de mim: O real, cara e coroa. São Paulo: Cosac Naify, 2004.

JACCOUD, Luciana de Barros; BEGHIN, Nathalie. Desigualdades raciais no Brasil: um balanço da intervenção governamental. Brasília: IPEA, 2002.

JAMESON, Fredric. Fim da arte ou fim da história. In: A cultura do dinheiro: ensaios sobre a globalização. Petrópolis: Vozes, 2001.

JASPERS, Karl. Introdução ao pensamento filosófico. Trad. Leônidas Hegenberg e Octanny Silveira da Mota. São Paulo: Cultrix, 1965.

KOWARICK, L.; FRÚGOLI JR, H. (org.). Pluralidade urbana em São Paulo: vulnerabilidade, marginalidade, ativismos. São Paulo: Editora 34, 2016.

LEIBNIZ, Gottfried. Os Pensadores. Trad. L. J. Baraúna. São Paulo: Abril Cultural, 1980.

LEBRUN, Gérard. A filosofia e sua história. São Paulo: Cosac Naify, 2006. . Passeios ao léu. São Paulo, Brasiliense, 1983.

LEFEBVRE, Henri. A revolução urbana. Belo Horizonte: Editora UFMG, 2002. . La production de l'espace. Paris: Éditions Anthropus, 1971.

LEROI-GOURHAN, André. Les racines du monde. Paris: Pierre Belfond, 1982. 
MÃE, Valter Hugo. O paraíso são os outros. São Paulo: Cosac Naify, 2014.

MAGNOLI, D. Tudo pelo social. Folha de S. Paulo, São Paulo, p. A-23, 3 mar. 2005. Disponível em <http://www1.folha.uol.com.br/fsp/opiniao/fz0303200507.htm>. Acesso em 08 fev. 2018.

MALINOWSKY, Bronislaw. Argonautas do Pacífico ocidental: um relato do empreendimento e da aventura dos nativos no arquipélago da Nova Guiné melanésia. $2^{\mathrm{a}}$ ed. São Paulo: Abril Cultural, 1978.

MARINHO, Andrea Rodrigues Barbosa. Círculo de cultura: origem histórica e perspectivas epistemológicas. São Paulo, 2014. Dissertação (Mestrado em Educação) - Faculdade de Educação, Universidade de São Paulo.

MARTENS, E. A questão de Sócrates: uma introdução. Trad. Vicente Sampaio. São Paulo: Editora Odysseus, 2013.

MARTINS, Gilberto de Andrade. Estudo de caso: uma estratégia de pesquisa. $2^{\mathrm{a}}$ ed. São Paulo: Atlas, 2008.

MASCARO, Alysson Leandro. Filosofia do Direito. $5^{\text {a }}$ ed. rev. e amp. São Paulo: Atlas, 2016.

MATIAS, Jacinto Antônio. Jovens urbanos: um programa no qual todos aprendemos. In: GUARÁ, Isa Maria F. (org.). Juventudes urbanas. São Paulo: Cadernos CENPEC, 2008.

MELO, Rúrion. Emancipação hoje e os desafios da democracia. Cadernos de Ética e Filosofia Política (USP), São Paulo, v. 23, p. 5-18, 2013.

MENDES, Maíra Tavares. Inclusão ou emancipação? Estudo de caso do Cursinho Chico Mendes/Rede Emancipa na Grande São Paulo. Porto Alegre, 2011. Dissertação (Mestrado em Educação) - Faculdade de Educação, Universidade Federal do Rio Grande do Sul.

. Cursinhos populares pré-universitários e educação popular: uma relação possível? 2011. Disponível em <https://redeemancipa.org.br/2011/05/343/>. Acesso em 12 ago. 2017.

MENEZES, Luis Carlos de. O novo público e a nova natureza do Ensino Médio. Estudos avançados, São Paulo, v. 15, n. 42, 2001.

MÉSZÁROS, István. A educação para além do capital. São Paulo: Boitempo, 2008.

MOTA NETO, J. C. A educação popular e o desenvolvimento de propostas pedagógicas na educação de jovens e adultos. In: CATELLI JR., Roberto (org.). Formação e pratica na educação de jovens a adultos. São Paulo: Ação Educativa, 2017.

NASCIMENTO, Alexandre do. Do direito à universidade à universalização de direitos: o movimento dos cursos pré-vestibulares populares e as políticas de ação afirmativa. Rio de Janeiro: Litteris Editora, 2012. 
. Universidade e cidadania: o movimento dos cursos pré-vestibulares populares.

Lugar Comum: Estudos de Mídia, Cultura e Democracia, Rio de Janeiro, n. 17, 2002.

NAVES, Márcio Bilharinho. Marxismo e direito: um estudo sobre Pachukanis. São Paulo: Boitempo, 2000.

NEGRI, Antonio; HARDT, Michael. Império. Rio de Janeiro: Record, 2000

NIETZSCHE, Friedrich. Crepúsculo dos idolos, ou, Como se filosofa com o martelo. Trad. Paulo César de Souza. São Paulo: Companhia das Letras, 2005.

NUNES, Benedito. Ensaios filosóficos. São Paulo: Editora WMF Martins Fontes, 2010.

NÚÑEZ-HURTADO, Carlos. Vigencia del pensamiento de Paulo Freire. Revista Educación de adultos y desarrollo, México, 2007, n. 69, 2007.

OLNEY, Queiroz Assis; KÜMPEL, Vitor Frederico. Manual de antropologia jurídica. São Paulo: Saraiva, 2011.

OLIVEIRA, Inês Barbosa de. Organização curricular e práticas pedagógicas na EJA: algumas reflexões. In: PAIVA, Jane.; OLIVEIRA, Inês Barbosa de. (Org). Educação de jovens e adultos. Petrópolis: De Petrus et Alli Editora, 2009.

PELOSO, Ranulfo (org.). Trabalho de base. São Paulo: Expressão Popular, 2012.

PENNAC, Daniel. Diário de escola. Rio de Janeiro: Rocco, 2008.

PEREIRA, Thiago Ingrassia. Pré-vestibulares populares em Porto Alegre: na fronteira entre o público e o privado. Porto Alegre, 2007. Dissertação (Mestrado em Educação) - Universidade Federal do Rio Grande do Sul.

PONTY, Merleau. O olho e o espírito. São Paulo: Cosac Naify, 2004.

POULANTZAS, Nicos. O Estado, o poder, o socialismo. São Paulo: Paz e Terra, 2000.

PINSKI, Jaime. Por que gostamos de história. São Paulo: Contexto, 2013.

QUINALHA, Renan. Lugares de fala e a urgência da escuta. Disponível em $<$ http://revistacult.uol.com.br/home/2015/11/lugares-de-fala-e-a-urgencia-da-escuta $>$. Acesso em 03 ago. 2016.

ROSENTHAL, Robert.; JACOBSON, Lenore. Pygmalion in the Classroom: Teacher expectation and pupils' intellectual development. Reino Unido: Crown House Publishing, 2003.

RIBEIRO, Marlene. Exclusão e educação social: conceitos em superfície e fundo. Educ. Soc., Campinas, v. 27, n. 94, 2006.

RICCI, Rudá. A complexa relação entre educação e movimentos sociais no Brasil ou Aventuras e Desventuras da Educação Popular em tempos difíceis. In: INSTITUTO SUPERIOR DE 
EDUCAÇÃO ANÍSIO TEIXEIRA/FUNDAÇÃO HELENA ANTIPOFF. Escritos em Educação. Belo Horizonte: Ibirité, 2004.

RICCIARDI, Giovanni. Espaço biográfico e literatura. In: CAIRO, L. R. et. Al (org.). Visões poéticas do espaço. Assis: Editora UNESP, 2008.

SACRISTÁN, José Gimeno. Educar e conviver na cultura global. Porto: Edições Asa, 2003.

SAFATLE, Vladimir. A política do Real de Slavoj Zizek. In: ZIZEK, S. Bem-vindos ao deserto do real. São Paulo: Boitempo, 2012.

SAFFIOTI, Allan. Crise e transformação: um estudo sobre a experiência de alunos de baixa renda num cursinho popular. São Paulo, 2008. Dissertação (Mestrado em Psicologia) - Instituto de Psicologia, Universidade de São Paulo.

SALGADO, Sebastião. Da minha terra à terra - Pela primeira vez, o maior fotojornalista do mundo conta sua história. Rio de Janeiro: Paralela, 2014.

SANTOS, Boaventura de Sousa. Poderá o direito ser emancipatório? Revista Crítica de Ciências Sociais, Coimbra, n. 65, 2003.

A universidade no século XXI: para uma reforma democrática e emancipatória da

universidade. Disponível em $<$ http://www.ces.uc.pt/bss/documentos/auniversidadedosecXXI.pdf $>$. Acesso em 10 fev. 2017.

SANTOS, Milton, A força do lugar. In: A natureza do espaço. $4^{\mathrm{a}}$ ed. São Paulo: Edusp, 2006.

. "O professor como intelectual na sociedade contemporânea". In: IX ENCONTRO NACIONAL DE DIDÁTICA E PRÁTICA DE ENSINO, vol. III, São Paulo. Anais...São Paulo: 1999.

SANTOS, Wagner Antônio. et al. Jovens urbanos: sistematização de uma metodologia. São Paulo: CENPEC, 2008.

SANTOS, Renato Emerson. Pré-vestibulares populares: dilemas políticos e desafios pedagógicos. In: CARVALHO, J. C. B.; ALVIM FILHO, H.; COSTA, R. P. (Org.). Cursos Pré-vestibulares Comunitários: espaços de mediação pedagógica. Rio de Janeiro: PUC-Rio, 2005.

SÃO PAULO (Município). Secretaria de Assistência Social. Mapa da Vulnerabilidade Social da População da Cidade de São Paulo. São Paulo: Cebrap, SESC e SAS-PMSP, 2004.

SARAMAGO, José. Prefácio. In: MÃE, Valter Hugo. O remorso de baltazar serapião. $2^{\mathrm{a}}$ ed. Rio de Janeiro: Biblioteca Azul, 2018.

SARLO, Beatriz. Tempo passado: cultura da memória e guinada subjetiva. Trad. Rosa Freire d'Aguiar. São Paulo: Companhia das Letras; Belo Horizonte: UFMG, 2007.

SCHMIDT, Maria Auxiliadora. A formação do professor de história. In: BITTENCOURT, C. (Org.). O saber histórico na sala de aula. São Paulo: Contexto, 1998. 
SEABRA, Odette Carvalho de Lima. Territórios do uso: cotidiano e modo de vida. Cidades, São Paulo, v. 2, n. 2, 2004.

SILVA, Roberto da. Os fundamentos freireanos da pedagogia social em construção no Brasil. Revista Interuniversitaria, n. 27, 2016.

SILVA, Tomaz Tadeu da. O currículo como fetiche: a poética e a política do texto curricular. Belo Horizonte: Autêntica, 2006.

SINGER, Paul. Poder, política e educação. Revista Brasileira de Educação, n. 1, 1996. . A economia dos serviços. Novos Estudos - CEBRAP, São Paulo, v. 2, n. 24, 1989.

SOUSA JÚNIOR, José Geraldo de. Direito como liberdade: o direito achado na rua. Porto Alegre: Sérgio Antônio Fabris, 2011.

SPÓSITO, Marília Pontes. Luta popular por educação: projeto de uma nova escola. Caderno do Cedi, São Paulo, n. 15, 1986,

STRECK, Danilo R. Entre emancipação e regulação: (des) encontros entre educação popular e movimentos sociais. Revista Brasileira de Educação, v. 15, n. 44, 2010.

TELLES, Vera da Silva; CABANES, Robert (org.). Nas tramas da cidade: trajetórias urbanas e seus territórios. São Paulo: Humanitas, 2006.

TELLES, Vera da Silva. Pobreza e cidadania. São Paulo: Editora 34.

TORRES, Alfonso. La educación popular: trayectoria y actualidad. Bogota: El Buho, 2011.

VALERY, P. O problema dos museus. Trad. V. Novis. Revista MAC, São Paulo, n. 2, nov. 1993.

VATTIMO, Gianni. O fim da modernidade: niilismo e hermenêutica na cultura pós-moderna, $2^{a}$ ed. São Paulo: Martins Fontes, 2007.

VYGOTSKY, L. S. A formação social da mente. Trad. José Cipolla Neto, Luis S. M. Barreto, Solange, C. Afeche. $3^{\text {a }}$ ed. São Paulo: Martins Fontes, 1989.

VON SIMSON, Olga R. de Moraes.; PARK, Margareth Brandini.; FERNANDES, Renata Sieiro. (Org.). Educação não-formal: cenários da criação. Campinas: Ed. Unicamp, 2001.

WEIS, Carlos. Direitos humanos contemporâneos. São Paulo: Malheiros Editores, 1999. . Em defesa das causas perdidas. São Paulo: Boitempo, 2011.

YIN, Robert. K. Estudo de caso: planejamento e métodos. $3^{\mathrm{a}}$ ed. Porto Alegre: Bookman, 2005. 
ZABALZA, Miguel. Os alunos universitários. In: O ensino universitário, seu cenário e seus protagonistas. Trad. Ernani Rosa. Porto Alegre: Artmed, 2004.

ZAGO, Nadir. Cursos Pré-vestibulares populares: limites e perspectivas. Perspectiva, Florianópolis, v. 26, n. 1, p. 149-174, 2008.

ŽIŽEK, Slavoj. Arriscar o impossível - conversas com Zizek. Trad. Vera Ribeiro. São Paulo: Martins Fontes, 2006. Coleção Dialética. 
ANEXO 1 - Apostila Cursinho do Grêmio - Filosofia (USP)

\section{Conhecimentos Gerais SERRIE DE EXERCIIIOS 1 2? EOICAO}




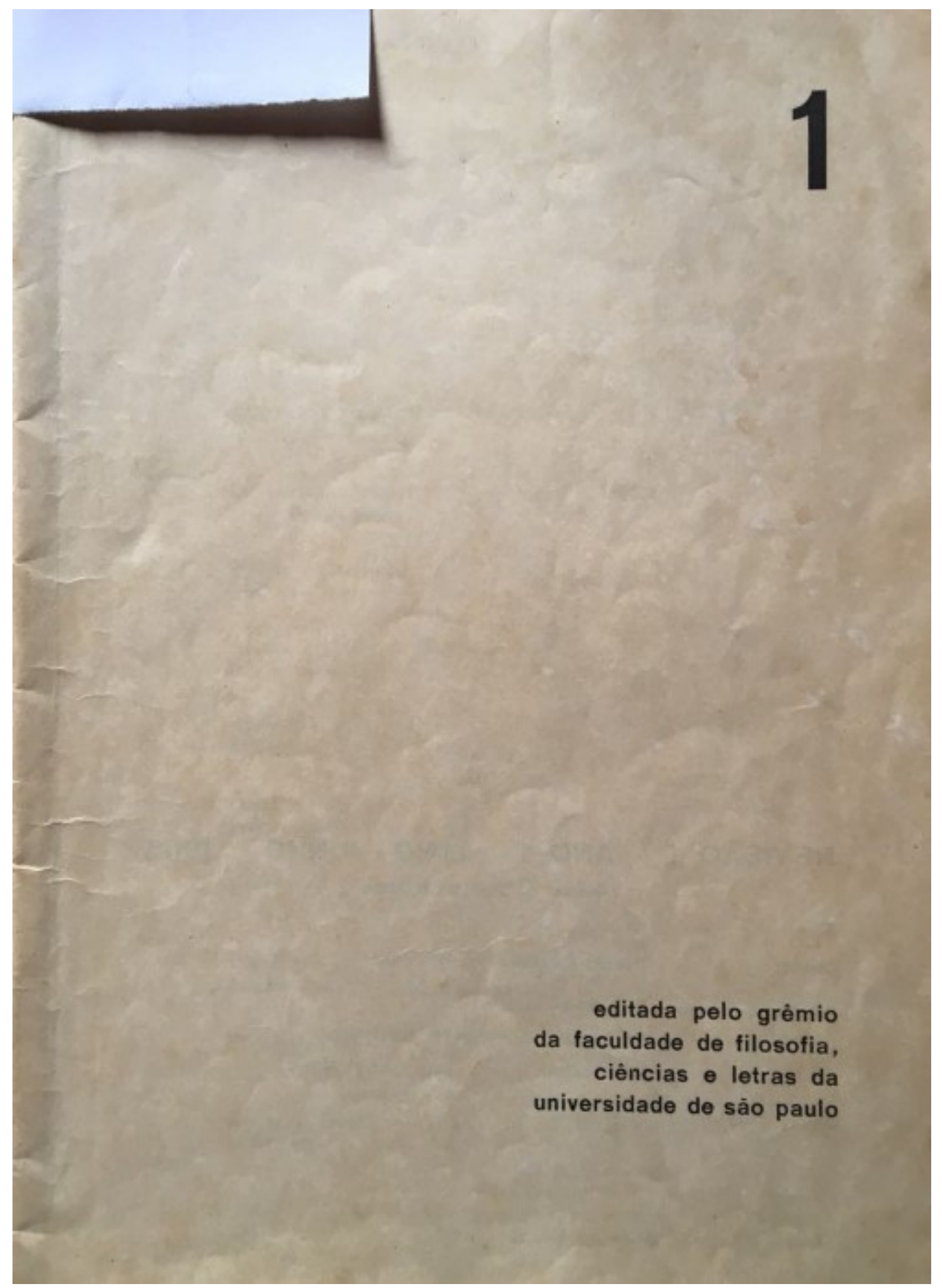




\section{ANEXO 2 - Carta aos professores e à direção do Cursinho da Poli (11/2004)}

São Paulo, 17 de novembro de 2004.

Desde sua retomada, em 1987, o projeto Cursinho da Poli do Grêmio Politécnico da Universidade de São Paulo passou por diversas mudanças a fim de ampliar e qualificar suas atividades em prol dos estudantes e da educação de maneira mais abrangente. Porém nos anos mais recentes algumas mudanças, sentidas e notadas por todos que dele participam ou participaram, têm conduzido a uma crise de identidade: qual a fisionomia do projeto social e como os estudantes, ex-estudantes, a comunidade universitária, professores e demais funcionários encaram-no hoje? Para isso precisamos voltar a pensar o espaço do Cursinho da Poli e seus rumos. :

A mais recente mudança deu-se no plano jurídico, ou seja, criou-se uma fundação privada com fins públicos. O que isso significa? Qual a garantia que esta figura jurídica dá ao projeto enquanto seus fins públicos?

Nós, proponentes abaixo assinados, apostamos na retomada das discussões de forma democrática e franca sobre os rumos do cursinho, na maneira mais adequada para enfrentar esses dilemas atuais. Sem retomarmos os alicerces do projeto de inclusão social e educacional tais dilemas só se aprofundarão. Retomar a tradição do Cursinho da Poli como parte do movimento social pela universidade pública, gratuita e de qualidade. Transformar o Cursinho da Poli num espaço público e democrático. Para isso precisamos superar coletivamente os entraves que tanto têm impedido esse diálogo.

Isso significa objetivamente: construir condições para oferecer vagas a um preço mais acessível e repensar o programa de bolsas no Cursinho da Poli, numa cidade que apresenta elevados índices de privação social ou, para usarmos a terminologia corrente, exclusão social. Promover a participação política de todos buscando contribuir na luta para transformar a cartografia da desigualdade social na cidade e não se tornar um agente de exclusão. Sabemos que não faltam dados qualificados para comprovar a situação de privação social vivida por mais da metade da população de São Paulo, praticamente entregue à própria sorte.

Priorizar a divulgação através de formas mais alternativas, retomando o contato com organizações sociais como Centros Acadêmicos (CA's) e DCE da USP, UNESP e UNICAMP, as escolas públicas, os movimentos de bairros, entre outros. Inserir o Cursinho da Poli no debate 
da reforma universitária, comprometido com uma verdadeira reforma universitária, centrada na universidade pública e não privada. Em suma, abrir a discussão de fato sobre o que é o Cursinho e a Fundação. Discutir e decidir coletivamente sobre as formas de gestão e decisão interna. Reconhecer a Associação dos Alunos (AACP) como entidade legítima dos estudantes. Promover uma educação a favor de uma juventude identificada com a realidade local e numa, escala crescente, com os anseios mais amplos da nação, ciente da necessidade de fortalecimento dos espaços públicos e em sintonia com a memória das lutas populares. Construir a emancipação política como meio esperançoso de atingirmos a consolidação dos direitos de cidadania.

Prof. Alessandro Dozena

Prof. Alexandre Bacci

Prof. André Villaça

Prof. Antonio Carlos da Silva (Tony)

Prof. Antonio Carlos Malaquias (Billy)

Prof $f^{a}$. Cristiane Bastos Ferreira

Prof. Danilo Braun

Prof $f^{a}$. Denise Lopes

Prof ${ }^{a}$. Eclicia Pereira

Prof $f^{a}$. Elaine Senise

Prof $f^{a}$. Eliane Romera (Nane)

Prof. Elias Feitosa

Prof. Fábio de Sá Cavalcanti

Prof. Gilberto Franca

Prof ${ }^{\mathrm{a}}$. Gisa

Prof. Greitony Ho

Prof. Haroldo

Prof ${ }^{\mathrm{a}}$. Ívian Lara Destro

Prof. Jackson Farias

Prof. Kleber Maia Marinho

Prof $f^{a}$ Luciana Franco Dias

Profa. Luciane Alves

Prof. Luciano Mendes

Prof. Márcio Alves 
Prof. Marcus Bianco

Prof. Paulo (Gramática).

Prof. Roberto Goulart Menezes

Profa. Rosane Preciosa.

Prof. Sérgio Pinheiro 
ANEXO 3 - Ofício para requisição das salas de aulas - Faculdade de História (USP)

\section{CURSINHO POPULAR FLORESTAN FERNANDES \\ UNIDADE BUTANTĀ - REDE EMANCIPA}

São Paulo, 24 de fevereiro de 2016.

Ref. Solicitação de Autorização para uso de 06 (seis) salas do prédio da Faculdade de História aos sábados ( $1^{\circ}$ semestre de 2016$)$.

Senhor Diretor,

Servimo-nos do presente para respeitosamente solicitar a renovação da permissão para utilização de seis salas do prédio da Faculdade de História desta Universidade de São Paulo, para as atividades letivas do Cursinho Popular Florestan Fernandes (Rede Emancipa de Cursinhos Populares) durante os sábados do primeiro semestre de 2016.

Trata-se de unidade que já desenvolveu durante todo o ano de 2015 seus trabalhos nessas salas do prédio da Faculdade de História; sob a supervisão estrita de alunos regularmente matriculados em cursos de graduação e pós-graduação da Universidade de São Paulo, sem quaisquer intercorrências.

Considerando o espaço urbano como manifestação social, buscando compatibilizar os diversos e complexos interesses que envolvem a cidade de forma a garantir o maior grau de fruição a todos, salientamos que referida concessão reveste-se de significativa relevância, notadamente, porque temos na atualidade o domínio dos cursinhos pré-vestibulares comerciais, os quais contemplam apenas uma infirma parte dos estudantes.

Cordial e atenciosamente,

llustríssimo Senhor,

Prof. Dr. Sérgio França Adorno de Abreu

DD. Diretor da Faculdade de Filosofia, Letras e Ciências Humanas (FFLCH). Universidade de São Paulo

Rua do Lago, 717 - Cidade Universitária, São Paulo, 05508-900/ São Paulo-SP. 


\section{ANEXO 4 - Carta do Cursinho Florestan Fernandes em ruptura à Rede Emancipa (2016) \\ CP Florestan Fernandes \\ 24 de abril de 2016 \\ NOTA DE DESLIGAMENTO DO CURSINHO POPULAR FLORESTAN FERNANDES DA REDE EMANCIPA}

É com orgulho da nossa militância e por acreditar no movimento que construímos que viemos, por meio desta nota, informar publicamente sobre nosso desligamento da Rede Emancipa.

Somos um Movimento Social de Educação Popular e acreditamos em um modelo de educação amplo e plural, construído coletivamente em espaços democráticos, onde coordenação, alunas e alunos, professoras e professores têm direito de participar de sua concepção teórica e prática.

Somos um movimento essencialmente voltado para quem teve e continua a ter espaços negados por uma estrutura racista, machista, homolesbobifóbica, transfóbica e elitista. Nossa militância cotidiana tem como objetivo maior que as universidades sejam ocupadas pela população preta, pobre e periférica. Espaço seu por direito, mas negado por este modelo meritocrático que é o vestibular. Lutamos por uma educação popular, em que todos estes setores oprimidos possam se expressar e se desenvolver livremente, sem barreiras físicas, econômicas e sociais.

Reivindicamo-nos um cursinho popular pré-universitário por acreditar que a nossa pedagogia transcende preparar alunas e alunos para uma prova; focamos numa formação crítica e desconstrutora dos padrões hegemônicos. Nossos espaços são políticos em sua essência, porque o nosso fazer pedagógico em si já é revolucionário. Buscamos atender a demanda de estudantes nos espaços de cursinho de acordo com nossas possibilidades, no intuito de contemplar a todas e todos; entretanto, isso não implica abrir mão do oferecimento de uma educação de qualidade, despreocupando-nos com o ensino em sala de aula ou reproduzindo uma lógica estatal de superlotação e massificação: “A massificação [...] resulta da ação do capital para reduzir os processos formativos às exigências estritas da reprodução do capital, daí muitas vezes suscitar a apatia dos estudantes ou sua revolta contra os sistemas de ensino" (Lúcia Bruno, "Educação e desenvolvimento econômico no Brasil”, Revista Brasileira de Educação, 
2011). Acreditamos que a educação como um todo pode ser ferramenta de luta, transformação e fortalecimento de todas e todos que a constroem.

Entristece-nos ver o movimento do qual fazíamos parte acusar companheiras de oportunismo em relação ao feminismo. Infelizmente, esta pauta não é capaz de nos blindar diante do machismo cotidiano. A luta das mulheres não é um escudo, mas uma arma de resistência que nos ajuda a enfrentar as opressões. Opressões estas presentes em todos os espaços, inclusive nos de militância; por isso nos é tão caro debater e reivindicar essas pautas. É importante frisar que todos os âmbitos do CPFF - coordenação, docência e discência - são compostos pelos mais diversos setores da sociedade e é fundamental que todas e todos sintamse acolhidos. Porém, isso não significa que relevaremos atitudes opressoras, inclusive e principalmente de nossas companheiras e companheiros. E isso se dá por entendermos que o companheirismo está em reconhecer os privilégios e buscar desconstruí-los a todo momento, principalmente quando nossas atitudes são questionadas por um setor oprimido.

A Rede Emancipa foi por algum tempo o movimento social que contemplou parte de nossas expectativas e perspectivas de militância, porém sentimos que a formulação política da Rede não se dá nos espaços de coordenação - compostos por representantes de todas unidades -, mas por coordenadores integrantes do Movimento Esquerda Socialista (MES), o que impossibilita a disputa do movimento pela base. A partir do momento em que tentamos colocar nossos posicionamentos e sentimos que eram considerados irrelevantes diante das linhas políticas formuladas previamente, as divergências acirraram-se, provocando nosso desligamento.

Tais divergências não têm a ver com a descrença de que não devemos ser um movimento social ou com um desentendimento pela presença partidária; acreditamos que a existência e a participação de partidos em movimentos sociais são legítimas e reflexos de um cenário democrático. Entretanto, prezamos por construir na base. Por formular as políticas coletivamente, nos espaços de círculo ou reunião, baseando-nos nas demandas materiais do cursinho e no cenário político atual, no lugar de promover políticas centralizadoras.

Nossa política é clara e honesta. Nossas decisões são tomadas em fóruns abertos de participação e buscam refletir as demandas concretas das e dos estudantes, professoras e professores. Preocupamo-nos primordialmente por travar um diálogo sincero com todas e todos que compõem o movimento, esclarecendo sempre nossas decisões e posicionamentos, qualquer que seja o tema. 
Em momento algum deixaremos de ser um movimento social democrático e aberto, que promove uma educação gratuita e de qualidade para qualquer pessoa que o quiser compor. Colocamo-nos à disposição para quaisquer esclarecimentos ou conversa sobre o assunto.

Força para todos os cursinhos populares e movimentos sociais que buscam combater essa estrutura que exclui e oprime. Ao Emancipa, agradecemos pelos anos de construção. Ao Cursinho Popular Florestan Fernandes e todos os movimentos parceiros, nossa luta só começou. 
ANEXO 5 - Grade horária - Cursinho Florestan Fernandes

\begin{tabular}{|c|c|c|c|c|c|c|}
\hline \multicolumn{7}{|c|}{ Sábado 1 (16/06) } \\
\hline & CAROLINA & FIRMINA & LIA & RAQUEL & ANA MARIA & LUANA \\
\hline 8.30 & Alegria (Biologia) & Zé (Literatura) & Esdras (Literatura) & $\begin{array}{l}\text { Gabriela } \\
\text { (Química) }\end{array}$ & Suellen (Biologia) & PH (Química) \\
\hline 09:20 & Zé (Literatura) & $\begin{array}{c}\text { Alegria } \\
\text { (Biologia) }\end{array}$ & Gabriela (Química) & $\begin{array}{c}\text { Esdras } \\
\text { (Literatura) }\end{array}$ & PH (Química) & $\begin{array}{c}\text { Eduardo } \\
\text { (Matemática 1) }\end{array}$ \\
\hline $10: 10$ & Intervalo & & & & & \\
\hline 10.25 & $\begin{array}{c}\text { Eduardo (Matemática } \\
\text { 1) }\end{array}$ & $\begin{array}{l}\text { Gabriela } \\
\text { (Química) }\end{array}$ & Fabi (Ling e Cód) & $\begin{array}{c}\text { Mara } \\
\text { (Sociologia) }\end{array}$ & Danilo (Filosofia) & Suellen (Biologia) \\
\hline 11.15 & Gabriela (Química) & $\begin{array}{l}\text { Círculo - } \\
\text { Esdras }\end{array}$ & Mara (Sociologia) & $\begin{array}{l}\text { Rapha (Ling } \\
\text { e Cód) }\end{array}$ & $\begin{array}{c}\text { Eduardo } \\
\text { (Matemática 1) }\end{array}$ & Danilo (Filosofia) \\
\hline 12.05 & Almoço/ Oficina & & & & & \\
\hline 13.25 & Círculo - Duda & $\begin{array}{l}\text { Fabi (Ling e } \\
\text { Cód) }\end{array}$ & $\begin{array}{c}\text { Matheus } \\
\text { (Geografia) }\end{array}$ & $\begin{array}{l}\text { Círculo - } \\
\text { Lara }\end{array}$ & Diogo(Sociologia) & Julio (História) \\
\hline 14.15 & Fabi (Ling e Cód) & $\begin{array}{c}\text { Matheus } \\
\text { (Geografia) }\end{array}$ & Círculo - Lara & $\begin{array}{c}\text { Duda } \\
\text { (História) }\end{array}$ & Julio (História) & Diogo(Sociologia) \\
\hline 15.05 & Intervalo & & & & & \\
\hline 15.20 & Matheus (Geografia) & OP & Tati (Matemática 1) & $\begin{array}{c}\text { Ursula } \\
\text { (Biologia) }\end{array}$ & OP & Círculo - Oluwa \\
\hline $16: 10$ & Stella (Filosofia) & $\begin{array}{c}\text { Tati } \\
\text { (Matemática 1) }\end{array}$ & OP & OP & Círculo - Oluwa & Diogo(Sociologia) \\
\hline 17.00 & $\mathrm{OP}$ & $\begin{array}{c}\text { Stella } \\
\text { (Filosofia) }\end{array}$ & Ursula (Biologia) & $\begin{array}{c}\text { Tati } \\
\text { (Matemática } \\
1) \\
\end{array}$ & Diogo(Sociologia) & $\mathrm{OP}$ \\
\hline $17: 50$ & $\begin{array}{l}\text { João, Sandro e } \\
\text { Beatriz (Inglês) }\end{array}$ & & & & & \\
\hline
\end{tabular}




\begin{tabular}{|c|c|c|c|c|c|c|}
\hline \multicolumn{7}{|c|}{ Sábado 2 (23/06) } \\
\hline & CAROLINA & FIRMINA & LIA & RAQUEL & ANA MARIA & LUANA \\
\hline 8.30 & Luiza (Redação) & Gabi(Redação) & $\begin{array}{c}\text { Beatriz (Matemática } \\
\text { 2) }\end{array}$ & $\begin{array}{c}\text { Beatriz } \\
\text { (Matemática } \\
\text { 2) }\end{array}$ & $\begin{array}{c}\text { Agustin } \\
\text { (Matemática 2) }\end{array}$ & $\begin{array}{c}\text { Agustin } \\
\text { (Matemática 2) }\end{array}$ \\
\hline 09:20 & Luiza (Redação) & Gabi(Redação) & $\begin{array}{c}\text { Beatriz (Matemática } \\
\text { 2) }\end{array}$ & $\begin{array}{c}\text { Beatriz } \\
\text { (Matemática } \\
\text { 2) } \\
\end{array}$ & $\begin{array}{c}\text { Agustin } \\
\text { (Matemática 2) }\end{array}$ & $\begin{array}{c}\text { Agustin } \\
\text { (Matemática 2) }\end{array}$ \\
\hline $10: 10$ & \multicolumn{2}{|l|}{ Intervalo } & & & & \\
\hline 10.25 & Luiza (Redação) & Gabi(Redação) & Gustavo (Filosofia) & \multicolumn{3}{|c|}{ Círculo Cotas - Emerson } \\
\hline 11.15 & \multicolumn{3}{|c|}{ Círculo Cotas - Emerson } & $\begin{array}{l}\text { Gustavo } \\
\text { (Filosofia) }\end{array}$ & Rafael (Física) & Luiza(Redação) \\
\hline 12.05 & \multicolumn{2}{|l|}{ Almoço } & & & & \\
\hline 13.25 & Matheus (Geografia) & $\begin{array}{c}\text { Lucas } \\
\text { (Matemática 2) }\end{array}$ & Rafael (Física) & $\begin{array}{c}\text { Paula } \\
\text { (Redação) }\end{array}$ & Denise(Redação) & Luiza(Redação) \\
\hline 14.15 & Juliana (Sociologia) & $\begin{array}{c}\text { Lucas } \\
\text { (Matemática 2) }\end{array}$ & Matheus (Geografia) & $\begin{array}{c}\text { Paula } \\
\text { (Redação) } \\
\end{array}$ & Denise(Redação) & Luiza(Redação) \\
\hline 15.05 & \multicolumn{2}{|l|}{ Intervalo } & & & & \\
\hline 15.20 & Victor (Física) & $\begin{array}{c}\text { Matheus } \\
\text { (Geografia) }\end{array}$ & Bia T (Redação) & $\begin{array}{c}\text { Paula } \\
\text { (Redação) }\end{array}$ & Denise(Redação) & $\begin{array}{c}\text { Mayara } \\
\text { (Geografia) }\end{array}$ \\
\hline $16: 10$ & $\begin{array}{l}\text { Lucas (Matemática } \\
\text { 2) }\end{array}$ & $\begin{array}{c}\text { Juliana } \\
\text { (Sociologia) }\end{array}$ & Bia T (Redação) & $\begin{array}{l}\text { Maria Eugênia } \\
\text { (Física) }\end{array}$ & $\begin{array}{c}\text { Mayara } \\
\text { (Geografia) }\end{array}$ & $\begin{array}{c}\text { Talita + Oluwa } \\
\text { (Revisão } \\
\text { Linguagens) } \\
\end{array}$ \\
\hline 17.00 & $\begin{array}{l}\text { Lucas (Matemática } \\
\text { 2) }\end{array}$ & Victor (Física) & Bia T (Redação) & $\begin{array}{c}\text { Mayara } \\
\text { (Geografia) }\end{array}$ & $\begin{array}{c}\text { Talita } \\
\text { (Literatura) + } \\
\text { Oluwa } \\
\text { (Linguagens e } \\
\text { códigos) } \\
\end{array}$ & $\begin{array}{l}\text { Maria Eugênia } \\
\text { (Física) }\end{array}$ \\
\hline $17: 50$ & $\begin{array}{l}\text { Cadu, Alessandra e } \\
\text { Juliana (Espanhol) }\end{array}$ & & & & & \\
\hline
\end{tabular}




\section{ANEXO 6 - Manual do aluno - Rede Emancipa}

\section{Apresentação}

Carxs alunxs do Florestan Fernandes 2015, mais um ano começa e estamos empolgadxs para a construção do cursinho. A participação de todxs é fundamental para que possamos manter o espaço cada vez mais aberto e democrático e é por isso que estabelecemos algumas orientações para o novo ano.

O caderno dxs estudantes deve servir como um guia; aqui você vai encontrar informações sobre o funcionamento do cursinho, um pouco da história da rede, depoimento de uma ex-aluna, entre outras coisinhas importantes para que o ano seja o mais proveitoso possível!Sejam bem vindxs e sintam-se convidadxs para construir com a gente!

Um beijo de seus profs lindxs $<3$

\section{História da Rede}

A Rede Emancipa - movimento social de cursinhos pré-universitários - foi fundada em 2007 na cidade de São Paulo e hoje conta com 16 projetos espalhados por 5 estados brasileiros. O objetivo principal é a defesa e luta pela democratização do acesso ao ensino superior, principalmente para estudantes da rede pública de ensino. Outro alicerce da Rede Emancipa é a luta contra a mercantilização da educação, dado que sua própria origem decorre da luta pelo fim da apropriação privada do Cursinho da Poli (fundado em 1987 e referência nacional no campo dos cursinhos populares) e restituição de seu caráter social. Assim, professores e exalunos que não concordavam com a nova estratégia política foram "convidados" a se retirar e, por fim, formou-se a Rede Emancipa. Dessa forma, não cobramos nenhum centavo do estudante - seja de matrícula ou material didático - e, para que isso seja possível, utilizamos espaço de escolas públicas e contamos com professores voluntários.

\section{Grade Horária}

Como temos muitas disciplinas e apenas um dia na semana, fizemos uma divisão dos professores em dois grupos. As aulas interdisciplinares são Ciências e Artes, que se alternam no segundo grupo (ou seja, acontecem uma vez por mês). Além disso, semanalmente realizamos uma roda de discussões que chamamos Círculo, e será explicado na próxima sessão.

\section{Círculo}


O Círculo é um espaço de dicussão e deliberação que ocorre toda semana. Nele, estudantes e professores sentam-se em roda e debatem sobre temas variados. Neste ano, decidimos adotar Temas Mensais para tornar os círculos mais eficientes e possibilitar que sejam alinhados com os conteúdos de cada disciplina. Os Temas são os seguintes:

\section{Educação}

2. Gênero e sexualidade (6 semanas)

3. Raça e Etnicidade

4. Cidade e Meio Ambiente (6 semanas)

5. Crime e Castigo

6. Nações e Conflitos Internacionais

7. Saúde e Alimentação

Além disso, adotamos o seguinte formato para os círculos:

Primeira semana: Aula-trabalho e coleta de materiais

Segunda semana: Subtema escolhido pelos estudantes

Terceira semana: Subtema escolhido pelos professores

Quarta semana: Tema livre

\section{Monitorias e Oficinas}

As Monitorias e Oficinas ocorrem durante o intervalo de almoço, e seu principal objetivo é ampliar os horizontes das atividades do cursinho para além do nosso tempo de aula reservado, e para além dos conteúdos do vestibular. As Monitorias acontecem no formato de "Plantão de Dúvidas", enquanto as Oficinas se baseiam em atividades de caráter prático.

Essas atividades podem ser oferecidas por professores, estudantes e por outros colaboradores. Se você tem interesse em oferecer uma atividade, ou conhece alguém, então avise-nos para que agendemos no cronograma!

\section{Espaços do cursinho e Estrutura}


O Cursinho é totalmente gratuito, mas através do esforço de todos os nossos colaboradores, conseguimos proporcionar uma estrutura razoável para o exercício de nossas atividades. O objetivo é que a cada semestre estejamos mais bem preparados!

Atualmente o Cursinho Popular Florestan Fernandes dispõe de cinco salas na Faculdade de História e Geografia na USP, duas delas com sistema audiovisual, além de acesso ao Centro acadêmico de História, que hospeda nossa biblioteca e armário, bem como geladeira e microondas para aqueles que trouxerem almoço.

Além disso, uma vez por mês, após o período de aula, realizaremos uma sessão de cinema na sala de televisão do CRUSP, que apelidamos carinhosamente de CineFlorestan.

Para transmitir informações e novidades, contamos com um jornal (que acompanha a lista de turmas semanalmente), além do mural do cursinho.

Também utilizamos no Facebook a página CP Florestan Fernandes e o grupo Cursinho FF 2015.

\section{Central do Aluno}

Desenvolvemos também a Central do Aluno, um sistema online criado para o cursinho. Através dele, pode-se acompanhar a grade horária das aulas, fazer download do material que os professores disponibilizam, verificar seu desempenho nos simulados, além de consultar as datas dos principais vestibulares do país.

Para utilizar, é muito simples, todos os alunos matriculados podem acessar o portal através do endereço:

\section{www.cpff.com.br}

Para o primeiro acesso, você deve se cadastrar através da aba LOGIN e após CADASTRE-SE !.

As Informações não serão divulgadas de nenhuma maneira. Sendo que as informações pessoais estarão apenas disponíveis para a coordenação e serão excluídas após o término do curso ou após a solicitação do aluno.

\section{Tutores}


O objetivo do Programa de Tutores é oferecer um acompanhamento pedagógico intensivo para todos os alunos do Cursinho. Cada professor terá aproximadamente 8 tutorandos, escolhidos de acordo com os critérios de localização geográfica e de área de interesse. Notem que o programa de tutores não impede o contato livre entre estudantes e professores, trata-se de um método desenvolvido para garantir que nenhum aluno passará pelo período de preparação para o vestibular desacompanhado de orientação pedagógica adequada. Sendo assim, não hesitem em nos contatar!

\section{Contato dos Professores}

\section{Ciências:}

Leonardo Lima (9 89544869 Tim) - leolima11@gmail.com

\section{Biologia:}

Thiago G. Pires (99125 5634 Claro) - thiagoalegria@hotmail.com Igor Ciambelli Soares de Oliveira (99876 8689 Vivo) - igorcsoaresdeoliveira@gmail.com

\section{Química:}

Julia Batista (96723 4820) - juliabgreati@gmail.com Marcos Vinicius (9 75967337 Vivo) - marcosv_carvalho@hotmail.com

\section{Física:}

Bruno Chagas (9 42666769 Vivo) - bru.chagas@hotmail.com

Francisco Sebastianelli (965866060 Vivo) - francisco_sebastianelli@hotmail.com

\section{Matemática:}

Ricardo Rocha (9 6457 6237) - drenamgb@hotmail.com

Adler Araújo Ribeiro Melo ( 949807722 Tim)- adlermelo1@gmail.com

\section{Geografia:}

Luan (96872 4545 oi) - avalanchecosmica@gmail.com Natasha Almeida Macedo (981474646) -natashaalmeidamacedo@gmail.com Amanda Magalhães (9 84284424 Tim)- amanda.maga.silva@gmail.com

\section{História:}


Stella Verzolla (98350-0721 Tim) - s_tangerino@yahoo.com.br

Veronica Fernandes (9 816 22399) - vefhist@gmail.com

\section{Sociologia:}

Julia Daher (98806 0180 Claro) - jdahermarques@gmail.com

Victor Augustus (984222218 Tim) - victor.augustus@gmail.com

\section{Redação:}

Graziela Drago (9 63939421 Vivo) - cxadagra@gmail.com Gilvandro Mendez (95343-8349) - gilvandro.monteiro@gmail.com Gabriela Omena (013982124790 Tim)-redacaofloresta@outlook.com

\section{Literatura:}

Ana Lúcia Orleans (9 52218749 Tim) - ana.orleans09@gmail.com Lara Rocha (970390257 Tim) - lararocha.9.2@gmail.com

\section{Espanhol:}

Talita Zanatta Alves (9 52834748 Tim) - talita_zanatta@hotmail.com Luciana Elena Vázquez (9 85772525 Vivo) - luvaz26@gmail.com Inglês:

Alessandra Brognára de Assis (9 5980 7635) - leka_brogbrog@hotmail.com Pablo Ibieta (9 4840 0420) - lil.titus@gmail.com

\section{Artes:}

Marcelo Felippe (97099-3327 Vivo ) - marceloboujikian@gmail.com 


\begin{tabular}{|c|c|c|c|}
\hline \multicolumn{4}{|c|}{ Cronograma CPFF 2015} \\
\hline \multicolumn{4}{|c|}{ Primeiro Semestre } \\
\hline \multicolumn{2}{|c|}{ Data } & Temas Mensais & Atividades \\
\hline & $28 / 02$ & & Aula Unificada \\
\hline \multirow{4}{*}{ MAR } & $07 / 03$ & Educaçào & Aula Inaugural \\
\hline & $14 / 03$ & & \\
\hline & $21 / 03$ & & \\
\hline & $28 / 03$ & & CineFlorestan \\
\hline \multirow{4}{*}{ ABR } & $04 / 04$ & Gênero e Sexualidade & \\
\hline & $11 / 04$ & & Dia na USP \\
\hline & $18 / 04$ & & Simulado $(19 / 04)$ \\
\hline & $25 / 04$ & & CineFlorestan \\
\hline \multirow{5}{*}{ MAI } & $02 / 05$ & & \\
\hline & $09 / 05$ & & \\
\hline & $16 / 05$ & & CineFlorestan \\
\hline & $23 / 05$ & Raça e Etnicidade & \\
\hline & $30 / 05$ & & Simulado $(31 / 05)$ \\
\hline \multirow{4}{*}{ JUN } & $06 / 06$ & & \\
\hline & $13 / 06$ & & CineFlorestan \\
\hline & $20 / 06$ & & \\
\hline & $28 / 06$ & & \\
\hline
\end{tabular}

\begin{tabular}{|c|c|c|c|}
\hline \multicolumn{4}{|c|}{ Segundo Semestre } \\
\hline \multicolumn{2}{|c|}{ Data } & Temas Mensais & Atividades \\
\hline \multirow{5}{*}{ AGO } & $01 / 08$ & & Aula Unificada \\
\hline & $08 / 08$ & Cidade e Meio Ambiente & Aula Inaugural \\
\hline & $15 / 08$ & & \\
\hline & $22 / 08$ & & \\
\hline & $29 / 08$ & & CineFlorestan \\
\hline \multirow{4}{*}{ SET } & $05 / 09$ & Crime e Castigo & \\
\hline & $12 / 09$ & & Simulado $(13 / 09)$ \\
\hline & $19 / 09$ & & \\
\hline & $26 / 09$ & & CineFlorestan \\
\hline \multirow{5}{*}{ OUT } & $03 / 10$ & Nações e Conflitos & Simulado $(04 / 10)$ \\
\hline & $10 / 10$ & & \\
\hline & $17 / 10$ & & \\
\hline & $24 / 10$ & & CineFlorestan \\
\hline & $31 / 10$ & Saúde e Alimentação & \\
\hline \multirow{4}{*}{ NOV } & $07 / 11$ & & \\
\hline & $14 / 11$ & & \\
\hline & $21 / 11$ & & CineFlorestan \\
\hline & $28 / 11$ & & \\
\hline \multirow{2}{*}{ DEZ } & $05 / 12$ & & \\
\hline & $12 / 12$ & & \\
\hline
\end{tabular}




\section{Florestan Feminista}

No nosso dia a dia passamos por inúmeras situações machistas. Desde pequenas definiram para nós que existe um jeito certo de se comportar. Lembra quando aquele cara decidiu que podia fazer comentários sobre o seu corpo? Lembra quando dirigiram a palavra exclusivamente ao homem que tava ao seu lado e não a você? Lembra quando te subestimaram ou interromperam o que você tava falando? É preciso estar atenta e forte. E quando estamos juntas fica um pouquinho mais fácil!

Surgiu em 2014 o coletivo feminista do Cursinho Popular Florestan Fernandes, com o intuito de criar e construir um espaço autorganizado de mulheres, que inclua professoras e alunas, a fim de conseguir empoderar umas às outras e fortalecer nossa luta e participação enquanto mulheres militantes, assim como construir acúmulos para ampliar nossa luta contra o machismo e conseguir pensar em conjunto soluções e prevenções para eventuais casos.

O Florestan Feminista acredita que discutir com os homens também é muito importante, e teremos várias oportunidades ao longo do ano para fazer isso. Porém, antes de tudo, acreditamos na sororidade. Aqui você fica a vontade para dizer o que você está sentindo, relatar experiências, participar de discussões e, principalmente, do pacto de fraternidade entre as mulheres que se reconhecem irmãs. O pacto é aliar-se, partilhar e principalmente mudar (e mudar-se) a sua própria realidade como mulher se libertando das diferentes opressões a que somos sujeitas. Nada mais é, que uma dimensão ética, política e prática do feminismo. Lugar de mulher é mudando o mundo! Vem mudar com a gente!

\section{Thaís Pereira Silva, 28}

\section{Aluna Emancipa (Florestan Fernandes - Butantã/ SP) em 2014}

Dez anos depois de sair do Ensino Médio decidi passar pelas maratonas vestibularescas mais uma vez. Senti que não conseguiria enfrentar todas as batalhas se eu não contasse com uma grande ajuda e foi assim que resolvi procurar um Cursinho pré-vestibular. Tendo estudado a vida inteira em escolas da rede pública terminei por achar um desaforo dos grandes pagar qualquer que seja a modalidade de ensino a não ser que seja absurdamente necessário e foi esse o principal motivo que me fez procurar um cursinho popular. Nunca havia frequentado "cursinhos" antes e acredito que aprendi como funciona um no lugar certo. Atraída pela gratuidade, fiquei pela dedicação dos/das professores/as-parceiros/as e de todos/as os/as colegas 
com os/as quais aprendi muito mais do que algumas dezenas de conteúdos para as provas. As conversas e os momentos dos "círculos" foram bastante ricos!

Mas apesar da super força que a galera do Emancipa, profas/es e estudantes, está disposta a dar, pra enfrentar as provas é preciso dedicação e empenho e uma boa boooooooooooa dose de cabeça fresca. Cada um de nós sabe de muitas coisas, ainda que não saiba de tudo, mas desesperar-se nas vésperas ou nos momentos das provas definitivamente não ajuda em nada. Organização e disciplina com os estudos são indispensáveis, assim como é indispensável a leveza de cada dia. Comer bem, dormir bem, ler, escrever e pesquisar enquanto estiver sendo dar muitas risadas e curtir esta fase da vida que é sim cheia de decisões a serem tomadas, mas que tem muitas alegrias. A vida não é moleza pra muitos/as de nós, sobretudo para aqueles/as que precisam conciliar rotinas de estudo e trabalho, mas é possível sim fazer quase tudo (ou pelo menos uma boa parte) daquilo a que nos propomos contanto que mantenhamos nosso foco. Universidade pública é um sonho alcançável quando persistimos! Não podemos nos deixar abater acreditando que estudantes de escola pública não consigam chegar lá ou ainda que um resultado ou outro que não seja tão satisfatório signifique que você não é capaz. Como diz uma grande amiga, "meritocracia é conversa pra boy dormir" e de meritocracia os vestibulares entendem bem, no entanto a vida é bem mais do que isso. 


\section{ANEXO 7 - Manual do professor - Rede Emancipa}

Mais um ano começa e estamos empolgadxs para a construção do cursinho. A participação de todas e todos é fundamental para que possamos manter o espaço cada vez mais aberto e democrático e é por isso que estabelecemos algumas orientações para o novo ano. Ao nos voluntariarmos para ser professora ou professor do Florestan precisamos ter em vista algumas obrigações:

\section{ORIENTAÇÕES TÉCNICAS:}

- Assiduidade nas aulas - A programação das aulas deve ser feita de maneira que as professoras e professores possam comparecer no horário estabelecido, porém, sabendo que imprevistos acontecem, estabelecemos o limite de 3 faltas - com aviso antecipado - por ano. Em caso de faltas injustificadas haverá uma advertência. Em caso de reincidência, ocorrerá o desligamento da professora ou professor.

*Quando não puder comparecer à aula, pedimos que cada professor se responsabilize por entrar em contato com colegas da área, e caso não possam, com de outras matérias, para avaliar a possibilidade de substituição. Segue ao final do manual a lista de contato das professoras e professores do Florestan 2015.

- Recomendamos a presença nas aulas inaugurais de cada semestre (março e agosto), pois é um momento importante de interação entre estudantes, professoras e professores.

- Entendendo a relevância dos círculos e de um debate cada vez mais amplo, orientamos que cada professxr participe de pelo menos um desses espaços por mês.

- Em 2015 o Florestan contará com duas reuniões mensais (um espaço de debate e formação e uma reunião deliberativa) agendadas previamente. Xs professorxs devem ter no mínimo $75 \%$ de presença nas reuniões.

- A Rede Emancipa conta com duas formações de professor ras e professores por ano. Recomendamos a participação em pelo menos uma dessas atividades.

- Cada um deve fazer um planejamento de suas aulas (cronograma anual) e utilizar a central de estudante, o que permitirá acesso de todos os conteúdos para professorxs e estudantes: 
- Para aproximar estudantes e professorxs e diminuir a evasão no cursinho, criamos o projeto de tutoria, em que cada professor é responsável por um grupo de alunas e alunos e tem a função de orientá-lxs e acompanhá-lxs no cursinho. Em breve disponibilizaremos mais informações sobre a tutoria.

\section{ORIENTAÇÕES DIDÁTICAS:}

- Converse com os professores da área sobre os programas da matéria e os cronogramas de aula (disponíveis na central de alunxs). Não esquecer de conferir o calendário geral para montar as aulas!

- Para montar o programa do curso, baseie-se em apostilas e livros didáticos, assim ficamos a par dos conteúdos dados tradicionalmente.

- No primeiro dia de aula, converse com os estudantes. Faça um levantamento dos cursos e universidades que a maioria prioriza e leve isso em consideração ao pensar o conteúdo.

- Sim, nosso tempo é curto e o conteúdo é grande, mas não entrem em desespero. As aulas devem ser concisas e claras. Aproveite o tempo de monitoria para passar mais exercícios e tirar as dúvidas. Além disso, as oficinas também podem ser utilizadas para propor atividades práticas relacionadas aos conteúdos.

- Caso os estudantes permaneçam com dúvidas sobre a matéria antiga, não adianta correr. A depender do número de estudantes, vale mais à pena revisar o conteúdo antigo e garantir a cla reza do que passar por cima das dúvidas. Caso sejam poucos, recorra aos monitores da matéria ou ao seu horário de plantão.

- Embora seja ideal que haja continuidade entre as aulas do programa, a configuração de cada turma costuma ser muito diferente ao longo do semestre (por conta de fatores como evasão e entrada de novos alunos). Neste caso, é pertinente consultar os alunos sobre seus conhecimentos dos conteúdos já discutidos (especialmente se tiverem relação com a aula em questão), além de fazer uma breve recapitulação e apontar outras fontes de estudo (material na central de alunos, espaços de monitoria, etc.)

- Dê preferência a materiais impressos nas aulas, para facilitar os estudos das alunas e alunos. Proponha atividades práticas em sala e para casa, os exercícios contribuem para a fixação e total aprendizagem dos conteúdos. 
- Recorra também a materiais multimídia, como músicas, filmes, slides, etc. Teremos duas salas com sistema audiovisual disponíveis, e seu uso deve ser agendado previamente com a coordenação.

- Somos todos professores-alunos! Encorajamos todos os professores a participarem das aulas de seus colegas (desde que estejam confortáveis para isso), esta é uma das formas mais eficientes de evoluir. Além disso, os conteúdos de cada disciplina muitas vezes se complementam nessas ocasiões, e as aulas ficam muito mais marcantes.

- Também é possível praticar estes conceitos de forma mais planejada, através da proposição de aulas-duplas, nas quais dois professores (de disciplinas diferentes ou não) medeiam o tema discutido conjuntamente. Verifique os cronogramas das demais disciplinas! Em alguns casos, pode ser produtivo juntar as aulas quando disciplinas diferentes abordam conteúdos semelhantes. As aulas-duplas devem ser avisadas antecipadamente para que se possam fazer os ajustes necessários na grade horária.

Rede Emancipa de cursinhos populares: educação de qualidade e inclusão social andam juntas!

A Rede Emancipa - movimento social de cursinhos pré-universitários - foi fundada em 2007 na cidade de São Paulo e hoje conta com 16 projetos espalhados por 5 estados brasileiros.O objetivo principal é a defesa e luta pela democratização do acesso ao ensino superior, principalmente para estudantes da rede pública de ensino. A Rede Emancipa deseja que a universidade "pública" seja ocupada por aqueles que a custeiam, ou seja, principalmente a população mais pobre de nossa sociedade. Outro alicerce do Emancipa é a luta contra a mercantilização da educação, dado que sua própria origem decorre da luta pelo fim da apropriação privada do Cursinho da Poli (fundado em 1987 e referência nacional no campo dos cursinhos populares) e restituição de seu caráter social. Assim, professores e ex-alunos que não concordavam com a nova estratégia política foram "convidados" a se retirar e, por fim, resultou na formação da Rede Emancipa. Dessa forma, não cobramos nenhum centavo do aluno - seja de matrícula ou material didático - e, para que isso seja possível, utilizamos espaço de escolas públicas e professores voluntários, os quais produzem seu próprio material didático. Nós da unidade Florestan Fernandes, utilizávamos a escola Emydgio de Barros, próximo à Portaria 3 da USP até o ano de 2013, porém a diretora, com o argumento de falta de segurança, impediu que continuássemos na escola e a partir de 2014 passamos a utilizar as salas da Faculdade de História da USP (sábados: 8h-18h). 
Os cursinhos populares são espaços nos quais a juventude encontra apoio e entusiasmo para completar sua formação secundária, bem como para lutar e sonhar coletivamente.Assim, construímos um projeto político-pedagógico que vai além do ensino para o vestibular, que possibilite à juventude um espaço inovador de debate, criação e recriação do saber acerca do mundo e da vida. Os professores contribuem - além de sua disciplina e conteúdo de vestibular - com oficinas culturais, debates nas aulas conhecidas como "Círculo" e apoio nos eventos em conjunto da Rede, como a "Aula inaugural Conscientização e luta contra a opressão

Aos esfarrapados do mundo

e aos que neles se

descobrem e, assim

descobrindo-se, com eles

sofrem, mas, sobretudo,

com eles lutam.

\section{OPRESSÃO}

A opressão é o efeito negativo experimentado por pessoas que são alvo do exercício cruel do poder numa sociedade ou grupo social. Ao anular a vocação humana de ser mais (ou seja, a liberdade de ir, de fazer, de opinar, de participar, de criar e de crescer), a opressão insere a dura realidade de ser menos (a negação ou diminuição destes direitos). A opressão se verifica hoje em situações concretas como a miséria, a desigualdade social, a exploração do trabalho, as relações autoritárias. Se verifica nas diferenças de salário, de representação política, de oportunidades, e de direitos básicos como segurança, saúde e educação.

Esta condição de heteronomia gerada pelas opressões reflete-se também em um acesso desigual à universidade. A limitação da liberdade afeta vestibulandxs, seja por sua raça, gênero, orientação sexual ou classe social. Desse modo é papel fundamental da Rede Emancipa lutar contra toda e qualquer opressão.

\section{REVISÃO DE PRIVILÉGIOS - PROFESSORXS}

Primeiro é preciso observar os privilégios que se tem. É fundamental que nós, professorxs, reconheçamos que muitas vezes podemos agir de forma opressora contra uma 
pessoa ou grupo de pessoas. Mesmo que você faça parte de um grupo oprimido, você pode agir de forma opressora contra outros grupos. Assim, apesar de você ser negrx, você pode agir de forma classista. Apesar de ser pobre, pode agir de forma transfóbica. Apesar de ser transexual ou travesti, pode agir de forma machista. Além disso, você pode agir de forma preconceituosa com o próprio grupo do qual você faz parte, como por exemplo, um homossexual pode agir de forma homofóbica com outros gays, por serem "afeminados" demais. Todos nós corremos o risco de ser opressores, porque nascemos e crescemos numa sociedade onde a cultura dominante é a opressora. Precisamos brigar contra isso dentro de nós, para que a nossa luta pela democratização da universidade inclua em vez de excluir, una em vez de descriminar. Só assim seremos um grupo forte e justo. Só assim o acesso à universidade será igual para todxs, sem exceções. Para tanto, faça o seguinte exercício de reflexão:

Você é de qual etnia?

Você sofre algum tipo de violência (física, verbal, psicológicas) por ser dessa etnia?

Em quais espaços você mais vê pessoas da sua etnia? Em shoppings, nas escolas e universidades, em museus, nos estádios, nas festas, nas periferias, no centro, nos presídios, nas zonas de prostituição, no subemprego, nos altos cargos?

As pessoas de sua etnia têm garantidos os seus direitos básicos (saúde, moradia, saneamento, educação, emprego, transporte, etc.) tanto quanto as outras etnias?

Você é ouvidx, quando precisa? As pessoas e as instituições tem interesse nas reivindicações da sua etnia?

Você é mais representadx na mídia que as outras etnias? E quando é, como te representam? Como isso se reflete nas suas perspectivas de vida?

Sua etnia é bem representada na política? Como isso se reflete nos seus direitos?

Quais outros privilégios sua etnia lhe traz?

Pense em como é cada uma destas questões para as outras etnias. Procure lembrar em que situações você já oprimiu pessoas de outras etnias (ou mesmo de sua própria etnia). Como você contribui para manter este estado de desigualdade? Pesquise e pergunte para pessoas de outras etnias como você pode melhorar e como deve agir para tornar a sociedade mais justa. Conheça os movimentos sociais que tratam deste tema. Procure entender os diferentes pontos 
de vista, debata e procure sempre se aprofundar mais na construção da sua consciência em relação a isso. E jamais, J-A-M-A-I-S, reproduza conceitos ou piadas em sala de aula que discriminem ou que reforcem estereótipos.

E então, refaça o questionário trocando "etnia" por gênero, por identidade de gênero, por orientação sexual, por classe social, por religião, por origem/nacionalidade, por presença ou não de deficiência e reflita novamente.

Apenas aceitaremos professorxs que tenham identificado os seus preconceitos, assumido que os têm e que estejam empenhadxs em quebrá-los. Para nos ajudarmos nesta tarefa é que existem os Círculos de Professorxs, onde nos reunimos mensalmente para discutir estes temas.

\section{AS ALUNAS E OS ALUNOS}

Não basta, porém, que apenas nós professorxs resolvamos nossos preconceitos. Para tornar o nosso cursinho num ambiente onde todos se sintam verdadeiramente bem-vindos, precisamos estender nossa reflexão aos alunos e alunas. Assim, também lhes damos a oportunidade de quebrarem seus pre conceitos, criando um ambiente de aceitação.

A grande maioria dxs nossxs alunxs provém de escolas públicas e não pode pagar um cursinho particular. Sob este ponto de vista, são pessoas oprimidas, já que lhes é diminuído um direito que deveria ser igual a todxs: o direito ao ensino superior. Porém isto não xs impede de reproduzir outras diversas formas de preconceito. Devemos promover junto com elxs a consciência de quem elxs são e de qual o seu papel na sociedade, enquanto oprimidxs. Mas também, a consciência de que elxs têm privilégios e muitas vezes podem agir como opressorxs. Só podemos promover a igualdade se estivermos unidxs, cooperando uns com os outros e para isso devemos quebrar nossos preconceitos.

\section{CONSCIÊNCIA DO PAPEL DE OPRIMIDX}

Segundo Freire, xs oprimidxs devem libertar e humanizar a si e aos opressores (da opressão específica sentida por cada oprimidx). São xs oprimidxs xs mais preparadxs para fazêlo, porque são elxs que sentem os efeitos da opressão e por isso podem melhor compreender a 
necessidade de se lutar pela libertação. Porém, existe uma série de ideias que estão introjetadas na mente dxs oprimidxs que dificultam esta compreensão.

Por esse motivo, apesar de em muitos casos xs oprimidxs serem maioria absoluta (como no caso da classe média-baixa), a desigualdade se mantém. Existe uma rede de ideologias que protege este sistema injusto e que imobiliza os oprimidos na luta por igualdade e justiça social.

Apenas para citar algumas: existe a visão mítica de que essa realidade é a vontade de Deus e nada pode ser feito para mudar a situação. Além disso, são difundidas as crenças na meritocracia, na neutralidade da lei e dos órgãos públicos.

Há, ainda, muitxs oprimidxs que "carregam x opressor(a) hospedadx dentro de si", pois na sociedade em que se formam, ter sucesso significa ser opressor(a). X oprimidx acaba adquirindo os valores dxs opressorxs, e assim o modelo de humanidade que vai procurar realizar é o dx opressor(a). Passará a defender a visão individualista de liberdade, o que lhe impede de lutar pela libertação de seu grupo. Esta dupla identidade precisa ser vencida dentro dx oprimidx.

Outra característica dxs oprimidxs é a "autodesvalia". Ela ocorre quando x oprimidx introjeta a visão que x opressor(a) possui delx. Daí consideram-se incapazes, enfermxs, dizem não saber nada, etc. Para superar a autodesvalia é necessário superar a visão mítica do mundo e descobrir a verdadeira causa da opressão. Para Freire, é na luta pela libertação que começam a crer em si mesmos e criam condições para superar a condição de heteronomia.

Do outro lado, a cada avanço $\mathrm{dx}$ oprimidx, $\mathrm{x}$ opressor(a) sentirá ameaçada a sua liberdade de oprimir e denunciará a violência e a desordem dos movimentos sociais. Na verdade o que xs opressorxs querem é invalidar o próprio movimento, para proteger seus privilégios.

Para vencer a contradição opressor(a)-oprimidx, são necessárias reflexão e ação. A reflexão é a construção de uma consciência de si e da realidade em que se está inseridx. A ação é uma proposta concreta de mudança dessa realidade. Uma não pode existir sem a outra. A reflexão é necessária para que possamos tomar uma ação de mudança consciente da realidade e sem essa ação, a reflexão não passa de verbalismo, de blablabla.

Na Rede Emancipa construímos espaços de reflexão e espaços de ação.

\section{O CURSINHO FLORESTAN FERNANDES INSERIDO NESTE CONTEXTO}


$\mathrm{Na}$ Rede Emancipa, temos um instrumento de reflexão e conscientização muito importante, que é o círculo de alunos. Os círculos acontecem uma vez a cada dia de aula e nele são discutidos diversos assuntos, quase sempre vinculados à opressão contra algum grupo, direta ou indiretamente. Além disso, buscamos trabalhar o tema em nossas aula e oficinas. A criação e a manutenção de nosso cursinho constitui um exemplo de ação no qual xs alunxs podem se espelhar e da qual podem também fazer parte, seja como colaboradorxs, monitorxs, oficineirxs ou mesmo professorxs e coordenadorxs

Estas são algumas de nossas ideias para tornar a universidade (e o mundo) mais justa e democrática. Esperamos que você professor(a) seja nossx parceirx nessa luta. Reveja seus privilégios, participe dos círculos de professorxs e de alunxs e traga as suas ideias para tornar o nosso cursinho mais tolerante e unido. Almejamos que você empodere seus/suas colegas e alunxs, ouvindo-os e dando-lhes apoio. Desejamos, enfim, que você goste de participar do cursinho, que você se encontre, faça amigos, ensine e aprenda junto conosco.

\section{FLORESTAN FEMINISTA}

No nosso dia a dia passamos por inúmeras situações machistas. Desde pequenas definiram para nós que existe um jeito certo de se comportar. Lembra quando aquele cara decidiu que podia fazer comentários sobre o seu corpo? Lembra quando dirigiram a palavra exclusivamente ao homem que tava ao seu lado e não a você? Lembra quando te subestimaram ou interromperam o que você tava falando? É preciso estar atenta e forte. E quando estamos juntas fica um pouquinho mais fácil!

Surgiu em 2014 o coletivo feminista do Cursinho Popular Florestan Fernandes, com o intuito de criar e construir um espaço autorganizado de mulheres, que inclua professoras e alunas, a fim de conseguir empoderar umas às outras e fortalecer nossa luta e participação enquanto mulheres militantes, assim como construir acúmulos para ampliar nossa luta contra o machismo e conseguir pensar em conjunto soluções e prevenções para eventuais casos.

O Florestan Feminista acredita que discutir com os homens também é muito importante, e teremos várias oportunidades ao longo do ano para fazer isso. Porém, antes de tudo, acreditamos na sororidade. Aqui você fica a vontade para dizer o que você está sentindo, relatar experiências, participar de discussões e, principalmente, do pacto de fraternidade entre as mulheres que se reconhecem irmãs. O pacto é aliar-se, partilhar e principalmente mudar (e mudar-se) a sua própria realidade como mulher se libertando das diferentes opressões a que 
somos sujeitas. Nada mais é, que uma dimensão ética, política e prática do feminismo. Lugar de mulher é mudando o mundo! Vem mudar com a gente!

\section{Contato dos Professores}

\section{Ciências:}

Leonardo Lima (98954 4869 Tim) - leolima11@gmail.com

\section{Biologia:}

Thiago G. Pires (9 91255634 Claro) - thiagoalegria@hotmail.com Igor Ciambelli Soares de Oliveira (998768689 Vivo) - igorcsoaresdeoliveira@gmail.com

\section{Química:}

Julia Batista (96723 4820) - juliabgreati@gmail.com

Marcos Vinicius (9 75967337 Vivo) - marcosv_carvalho@hotmail.com

\section{Física:}

Bruno Chagas (9 42666769 Vivo) - bru.chagas@hotmail.com

Francisco Sebastianelli (965866060 Vivo) - francisco_sebastianelli@hotmail.com

\section{Matemática:}

Ricardo Rocha (9 6457 6237) - drenamgb@hotmail.com

Adler Araújo Ribeiro Melo ( 949807722 Tim)- adlermelo1@gmail.com

\section{Geografia:}

Luan (96872 4545 oi) - avalanchecosmica@gmail.com Natasha Almeida Macedo (981474646) -natashaalmeidamacedo@gmail.com Amanda Magalhães (9 84284424 Tim)- amanda.maga.silva@gmail.com

\section{História:}

Stella Verzolla (98350-0721 Tim) - s_tangerino@yahoo.com.br Veronica Fernandes (9 816 22399) - vefhist@gmail.com

\section{Sociologia:}

Julia Daher (9 88060180 Claro) - jdahermarques@gmail.com Victor Augustus (984222218 Tim) - victor.augustus@gmail.com 


\section{Redação:}

Graziela Drago (963939421 Vivo) - cxadagra@gmail.com

Gilvandro Mendez (95343-8349) - gilvandro.monteiro@gmail.com

Gabriela Omena (013982124790 Tim)-redacaofloresta@outlook.com

\section{Literatura:}

Ana Lúcia Orleans (952218749 Tim) - ana.orleans09@gmail.com Lara Rocha (970390257 Tim) - lararocha.9.2@gmail.com

\section{Espanhol:}

Talita Zanatta Alves (9 52834748 Tim) - talita_zanatta@hotmail.com Luciana Elena Vázquez (985772525 Vivo) - luvaz26@gmail.com

\section{Inglês:}

Alessandra Brognára de Assis (9 5980 7635) - leka_brogbrog@hotmail.com Pablo Ibieta (9 4840 0420) - lil.titus@gmail.com

\section{Artes:}

Marcelo Felippe (97099-3327 Vivo ) - marceloboujikian@gmail.com 


\section{ANEXO 8 - Cronograma unificado dos conteúdos por disciplina}

\section{CRONOGRAMA DE INGLÊS}

1. Inglês como "língua global" (?)

2. Estratégias de Leitura em língua inglesa + Uso do dicionário

3. Estratégias de Leitura (continuação)

4. Classes de palavra do inglês

5. Sintagma Nominal

6. Sintagma Verbal (noções gerais + modais)

7. Sintagma Verbal (aspecto simples vs. aspecto contínuo)

8. Sintagma Verbal (aspecto perfeito)

9. Phrasal verbs

10. Linking Words

11. Linking Words (continuação)

12. Revisão

\section{CRONOGRAMA DE LINGUAGENS E CÓDIGOS}

1. Aula inaugural - $O$ que é aprender português?

Os países de língua portuguesa | Totonha, de Marcelino Freire.

2. Nunca me sonharam - Reflexões e escrita sobre os próprios sonhos

3. Variantes linguísticas, norma culta/popular

A norma culta e as variedades linguísticas

4. Linguagem e modernismo: Geração de 22 (A grande militância pela linguagem) A linguagem da perspectiva da literatura: A Geração de 22

\section{Texto e contexto}

Iniciação aos Gêneros Textuais em diálogo com outras disciplinas

\section{Linguagem e realismo}

Machado de Assis 


\section{Gêneros textuais}

Textos verbais e não verbais

8. Intertextualidade e arte

9. Classe de palavras

10. Depreensão de palavras

11. Linguagem e contemporaneidade

Mayombe, de PEPETELA.

12. Funções da linguagem

13. Figuras de linguagem

14. Linguagem e romantismo

15. Tudo o que você sempre quis saber sobre linguagem!

\section{CRONOGRAMA DE LITERATURA}

1. Literatura pra quê? / Por que estudar literatura? / Qual o papel da literatura?

Obra: Diversos trechos de prosa e poesia

2. Panorama do Trovadorismo / Humanismo

Obra: Auto da barca do Inferno, de Gil Vicente/ Cantigas de amor, amigo e escárnio

3. Brasil colônia e renascimento cultural europeu: Classicismo, Quinhentismo e Barroco Obras: Carta a El-Rei Dom Manuel de Pero Vaz Caminha / Poemas de Gregório de Mattos

4. Romantismo - Introdução e contexto histórico

Obra: A Relíquia de Eça de Queiroz

5. O Romantismo no Brasil e suas fases

Obra: Canção do Exílio de Gonçalves Dias e outros poemas

6. A prosa no Romantismo

Obra: Minhas Vida de Menina de Helena Morley (1893-1895) e Iracema (1865) de José de Alencar

7. Início e conceitos do movimento realista no Brasil 
Obra: Memórias Póstumas de Brás Cubas (1880) de Machado de Assis.

\section{O movimento naturalista}

Obra: O cortiço (1890) de Aluísio de Azevedo

9. Introdução ao modernismo: Semana de Arte de 1922 / Vanguardas/ $1^{\text {a }}$ fase

Obra: Poemas de Manuel Bandeira, Carlos Drummond de Andrade, Oswald de Andrade e Mário de Andrade

10. Romance de $30 / 2^{\text {a }}$ fase do modernismo

Obra: Vidas Secas (1938) - Graciliano Ramos

11. A cidade, a linguagem e o imaginário na geração de $45 / 3^{\circ}$ fase do Modernismo

Obra: Sagarana (1946) de Guimarães Rosa

\section{O estudo da poesia}

Obra: Claro Enigma (1951) de Carlos Drummond de Andrade

13. Tropicalismo (1968) e o resgate à Antropofagia

Obra: Trechos de Torquato Neto, Caetano Veloso e Gilberto Gil

14. Uma breve introdução à Literatura Africana e os movimentos por independência em Angola.

Obra: Mayombe (1980) de Pepetela

15. A escrevivência de Carolina Maria de Jesus

Obra: Quarto de Despejo (1960) de Carolina Maria de Jesus

16. A geração mimeógrafo e Ana C.

Obra: A teus pés (1982) de Ana Cristina César

\section{CRONOGRAMA DE HISTÓRIA}

1. Introdução e antiguidade oriental

2. Antiguidade clássica - Grécia e Roma

3. Declínio do Império Romano do Ocidente | Império de Carlos Magno | Império Bizantino

4. Feudalismo | Transição para a época moderna

\section{História Geral}


Formação das monarquias nacionais | Renascimento e Iluminismo |

Reforma e contrarreforma

\section{História do Brasil}

A expansão marítimo-comercial europeia $\mid$ América portuguesa

\section{História do Brasil}

Brasil monárquico | Transição para a República (começo do século XIX)

8. América espanhola e América inglesa

\section{História Geral}

História contemporânea

\section{História Geral + História do Brasil}

Continuação da História contemporânea (H. Geral) | Brasil Repúblicano (1889 a 1929)

\section{História do Brasil}

Governo de Getúlio Vargas (1930 a 1945) | Brasil Republicano (1945 a 1964)

\section{História do Brasil}

Ditadura militar (1964 a 1985)| Brasil republicano (1985 - 2018)

\section{CRONOGRAMA DE GEOGRAFIA}

1. O que é Geografia? A produção do espaço no contexto capitalista global.

2. O modo de produção capitalista.

3. Cidades globais e Globalização: uma nova ordem econômica mundial.

4. O Planeta Terra.

5. Os mapas e a linguagem cartográfica.

6. Climatologia

7. Noções de Geologia

8. Biomas do mundo e Domínios Morfoclimáticos brasileiros.

9. O Brasil Agrário - Ciclos econômicos e a inserção do Brasil na 
Divisão Internacional do Trabalho Êxodo Rural e Reforma Agrária no Brasil - Dinâmicas populacionais e pirâmide etária.

10. Industrialização e Urbanização

11. Industrialização Brasileira e a nova inserção econômica do Brasil no mundo

12. Os BRICS, a América Latina, Ásia, África: novas articulações e

regionalizações mundiais

13. Escalas locais, escalas globais, e as novas configurações da

Atualidade

14. Revisão e Resolução de questões em grupo.

\section{CRONOGRAMA DE MATEMÁTICA - ÁLGEBRA}

1. Aula inaugural: Exatas

2. Operações com frações

3. Razão, proporção e escala I

4. Razão, proporção e escala II

5. Operações com decimais

6. Porcentagem, aumento, desconto e juros I

7. Porcentagem, aumento, desconto e juros II

8. Potenciação e radiciação

9. Produtos notáveis e fatoração

10. Funções $\left(1^{\circ}\right.$ e $2^{\circ}$ grau $)$ I

11. Funções $\left(1^{\circ}\right.$ e $2^{\circ}$ grau $)$ II

12. Interpretação de gráficos

13. Sequências (progressão aritmética e geométrica) I

14. Sequências (progressão aritmética e geométrica) II

15. Estatística (média, moda, mediana, variância e desvio padrão)

16. Fatorial e análise combinatória I 
17. Fatorial e análise combinatória II

18. Probabilidade

19. Logaritmos

20. Geometria analítica

21. Revisão Enem

\section{CRONOGRAMA DE MATEMÁTICA - GEOMETRIA}

1. Ângulos (complementares, suplementares, reto, raso) e conversão graus radianos

2. Paralelas e transversais (ângulos opostos pelo vértice, ângulos alternos internos, soma dos ângulos internos do triângulo)

3. Semelhança de triângulos

4. Teorema de Pitágoras

5. Área de figuras planas

6. Círculo e setor circular I

7. Círculo e setor circular II

8. Trigonometria no triângulo retângulo (seno, cosseno e tangente)

9. Cilindros e prismas

10. Cones e pirâmides

11. Esferas

12. Relação fundamental da trigonometria

13. Revisão Enem

\section{CRONOGRAMA DE FÍSICA}

1. Ondulatória e ótica física

Conceitos físicos relacionados ao comportamento "físico"da

luz | Noções ondulatórias, natureza, tipos, grandezas relacionadas, equação fundamental da ondulatória e estudo do som.

2. Eletricidade

Conceitos básicos da eletrostática, tais como a noção de 
carga elétrica, princípios relacionados e processos de eletrização | Conceitos básicos de eletrodinâmica, tais como a corrente

elétrica, diferença de potencial, componentes de um circuito, etc.

3. Magnetismo

Campo magnético, propriedades dos ímãs, magnetismo terrestre

e força de Lorentz.

4. Propriedades da matéria

Propriedades gerais da matéria como massa, volume e Elasticidade | Propriedades físicas da matéria como solubilidade, densidade e ponto de fusão.

5. Noções básicas de cinemática

Movimentos uniforme e uniformemente acelerado, envolvendo

conceitos de velocidade e aceleração |Lançamentos oblíquos e movimento circular uniforme.

6. Noções básicas de dinâmica

Conceito de força e as leis de Newton.

7. Mecânica dos fluidos

Conceitos como empuxo, pressão e leis relacionados ao estudo

de corpos imersos em fluidos.

8. Calorimetria

Noção de calor e sua propagação e as leis da termodinâmica.

9. Energia

Definições de energia cinética, potencial elástica, potencial gravitacional e mecânica.

10. Trabalho e potência

Definição: trabalho de uma força constante, de um

sistema de forças e de uma força de intensidade variável; teorema do trabalho e energia cinética, assim como o conceito

de potência. 
11. Ótica geométrica

Tipos de fontes de luz, princípios relacionados ao comportamento

geométrico da luz, a noção de reflexão e refração da luz | Lentes e espelhos esféricos.

12. Gravitação

As leis de Kepler e a força de atração gravitacional entre corpos.

\section{CRONOGRAMA DE FILOSOFIA}

\section{Mito X Razão (Uma ruptura?)}

Pré-Socráticos (Tales, Heráclito e Parmênides)

\section{Sócrates e Platão}

a. Sócrates X Sofistas | b. A concepção idealista do mundo: sensível X inteligível

\section{Aristóteles}

Conceitos centrais dos livros Metafísica, Órganon e Política.

\section{Filosofia medieval}

Agostinho, Boécio e Tomás de Aquino

\section{Tópicos de filosofia moderna}

Principais ideias de filósofos modernos, tais como Maquiavel, Montaigne e Espinoza

\section{Racionalismo cartesiano X Empirismo inglês e a Crítica kantiana}

a. Racionalismo, cogito e ideias inatas (Descartes) $\mid$ b. Experiência sensível como origem das ideias | c. O fim da metafísica e os limites do conhecimento

\section{7. Ética}

a. Ética a Nicômaco (Aristóteles)|b. Ética kantiana| c. O utilitarismo de Jeremy Bentham e Stuart Mill | d. Ética kantiana X Ética utilitarista

\section{Estética}

a. Crítica platônica da arte como simulacro | b. O juízo estético kantiano

\section{Hegel, Marx e marxismos}

a. Concepção idealista da história (o Ser Absoluto) | b. Materialismo histórico-dialético (luta de classes como motor da história) | c. Crítica da economia política (modo de produção, relações 
de produção, força de trabalho, reprodução das relações de produção, mais-valor, valor de uso e valor de troca, mercadoria)

\section{Existencialismo}

Sartre e Beauvoir (Grada Kilomba)

\section{Conceitos}

Discussão de alguns conceitos que perpassam por toda a história da filosofia, tais como: Metafísica, Ética, Moral, Estética, Idealismo, Materialismo, Racionalismo, Empirismo, Lógos, Razão, Justiça, Determinismo, Liberdade, etc.

\section{Revisão}

\section{CRONOGRAMA DE QUÍMICA}

1. Tabela periódica, propriedades periódicas e íons monoatômicos

2. Ligações químicas: metálica, covalente e iônica

3. Forças intermoleculares (íon dipolo, dipolo-dipolo, dipolo induzido e ligação de hidrogênio)

4. Nomenclatura e funções de compostos inorgânicos

5. Reações de compostos inorgânicos (precipitação, neutralização)

6. Massa atômica e mol

7. Estequiometria

8. Funções de compostos orgânicos e isomeria

9. Reações Orgânicas

10. Equilíbrios químicos: $\mathrm{Kc}, \mathrm{Kp}, \mathrm{pH}, \mathrm{Kps}, \mathrm{Ka}$ (parte I)

11. Equilíbrios químicos: Kc, Kp, pH, Kps, Ka (parte II)

12. Eletroquímica: redox e pilhas

13. Eletroquímica: pilhas e eletrólise

14. Termoquímica

\section{CRONOGRAMA DE REDAÇÃO}

\section{Escrita e cidadania e a função social da escrita}

Produção: a relação do estudante com a Língua, escrita e leitura 
2. O que é texto? Tipologias textuais

Produção: Elaboração de projeto de texto

3. O que é argumentar?

Produção: Argumentação na oralidade

4. Começo, meio e fim, coesão e coerência e a estrutura textual

Produção: texto dissertativo-argumentativo em gênero diverso

5. A estrutura de um texto para vestibular | Gramática I

Produção: redação no modelo ENEM

6. Argumentar para desenvolver | Gramática II

Produção: redação no modelo ENEM

7. Eu argumento, eu concluo, eu proponho solução | Gramática III

Produção: redação no modelo ENEM

8. Introdução de uma dissertação argumentativa + As competências do ENEM

Produção: redação no modelo ENEM

9. Reler é preciso: retomada dos elementos para um texto com começo, meio e fím + práticas de melhoria na argumentação

Produção: redação em modelo de vestibular diverso

10. Praticas de melhorias na intro, conclusão e intervenção

Produção: redação em modelo a ser definido

11. Quais são as suas demandas?

Aula reservada para demandas de escrita detectadas ao longo do ano

12. Quais são as suas demandas?

Aula reservada para demandas de escrita detectadas ao longo do ano

13. Quais são as suas demandas?

Aula reservada para demandas de escrita detectadas ao longo do ano

14. Quais são as suas demandas? 
Aula reservada para demandas de escrita detectadas ao longo do ano

\section{CRONOGRAMA DE ESPANHOL}

\section{Latinoamérica}

Mapa e músicas

\section{Tópicos gramaticais}

Verbos (ser e estar) e pronomes tônicos

3. Violência contra a mulher

\section{Tópicos Gramaticais}

Pronomes átonos e artigos

5. Migração

México, Bolívia e Venezuela

6. Tópicos Gramaticais

Conjunções, falsos cognatos e heterogenéricos

7. A ditadura na Argentina e as avós da Plaza de Mayo

8. Atualidades

¿Qué pasa ahora?

9. Simulado

Aplicação e correção

10. Principais dificuldades com o simulado

11. Pensar la lengua en el siglo XXI

Muy/Mucho; palavras homônimas

12. Raça e Racismo no mundo hispânico

13. Revisão geral

\section{CRONOGRAMA DE BIOLOGIA}

1. Vida: o início

Definição de vida e suas moléculas. 


\section{A célula}

Tipos de célula; organelas e seu funcionamento.

\section{Energia}

Processos de transformação: respiração, fermentação e fotossíntese.

\section{Dogma central}

Do gene ao fenótipo.

\section{Processos de divisão celular}

Mitose, meiose e suas implicações.

\section{Genética I}

Leis gerais da hereditariedade, heredogramas, genótipo e fenótipo.

\section{Genética II}

Herança ligada ao sexo e cálculos de probabilidade.

8. Evolução - visão geral

Introdução ao processo de evolução (paradigma de sustentação).

\section{Classificação biológica + zoologia}

Nomenclatura, organização e classificação dos seres vivos; principais grupos animais.

\section{Fisiologia animal e humana}

Órgãos e sistemas dos animais

\section{Botânica}

Grandes grupos vegetais; estruturas vegetais; fisiologia vegetal.

\section{Ecologia I}

Ciclos Biogeoquímicos.

\section{Ecologia II}

Seres vivos e o ambiente.

\section{Atualidades em biologia}

Principais tópicos abordados na mídia envolvendo saúde, ciência e meio ambiente. 


\section{CRONOGRAMA DE SOCIOLOGIA}

\section{A. Introdução à sociologia}

1. O que é sociologia?

B. Clássicos da sociologia

2. Émilie Durkheim

3. Karl Marx

4. Max Weber

C. Diferenças e desigualdades

5. Por que falar em gênero?

6. Racismo à brasileira?

7. Os direitos humanos devem ser universais?

8. Quem é índio no Brasil?

D. Estado, política, poder e instituições

9. Por que nos organizamos em sociedade?

10. A política é sempre igual?

11. Como se governa o Brasil?

12. Somos cidadãos?

13. Haveria um quarto poder 
ANEXO 9 - Oficinas e atividades desevolvidas no Cursinho Popular Florestan Fernandes
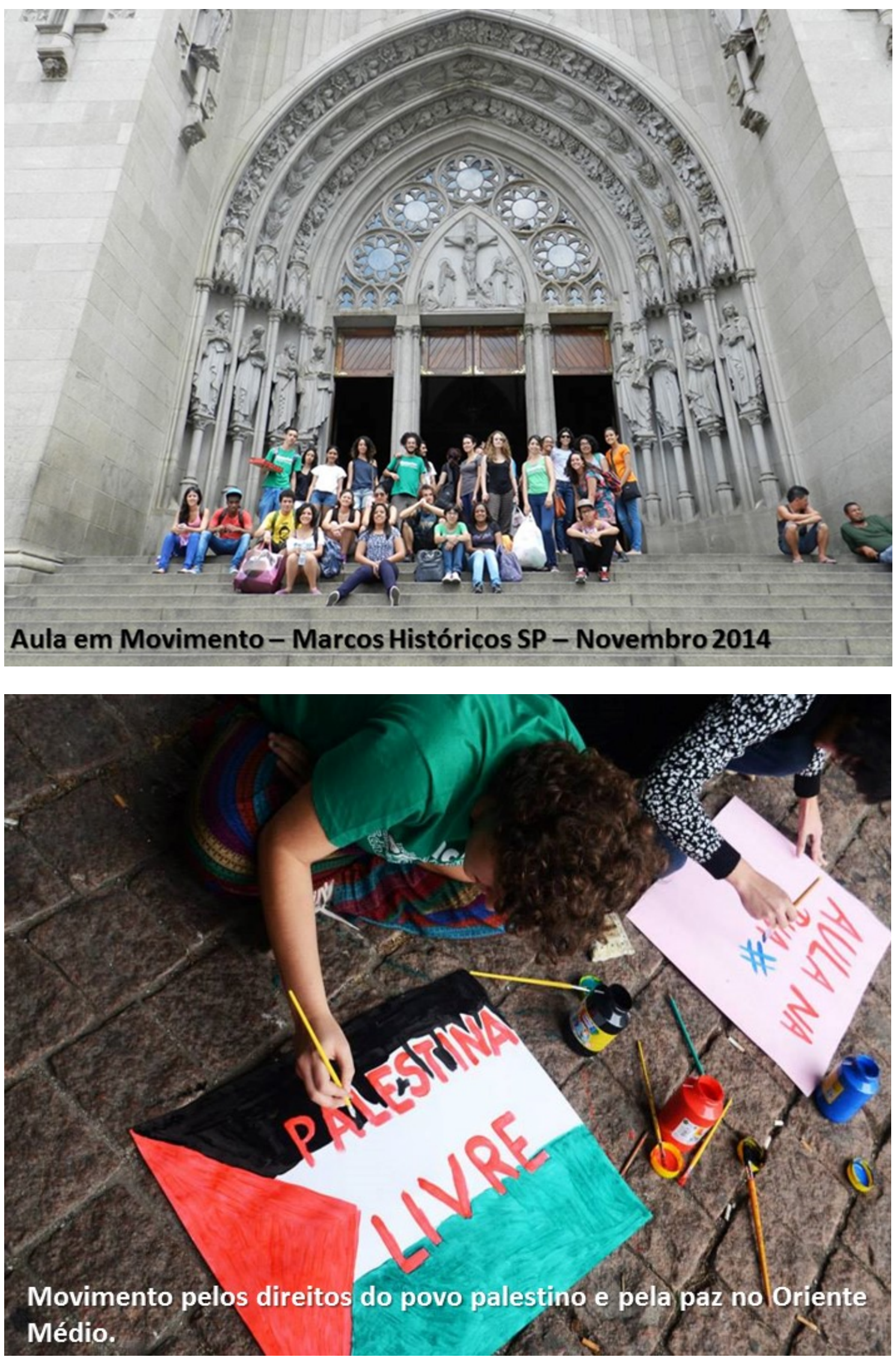


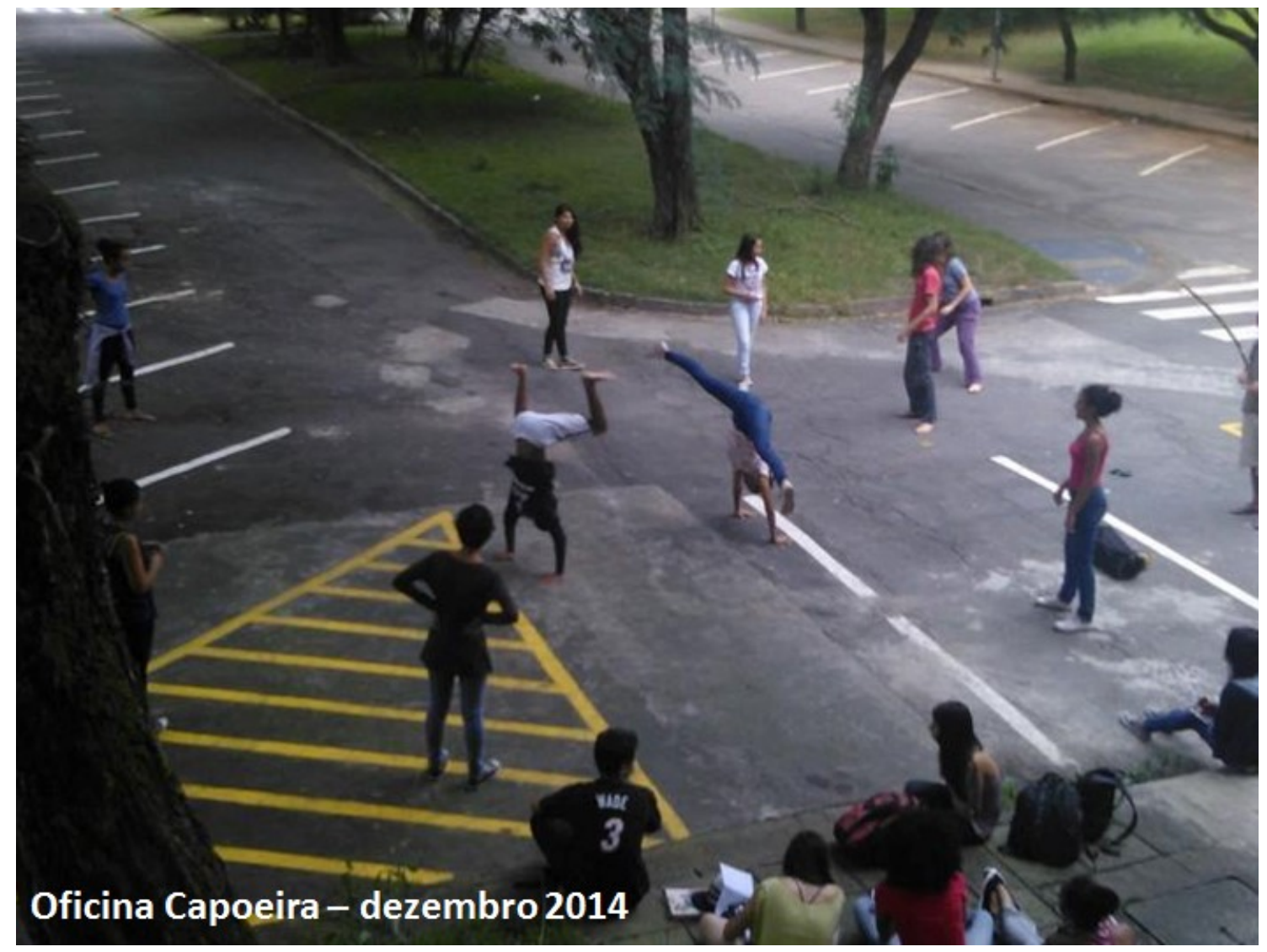

\section{Ato contra aumento passagem - junho 2013}

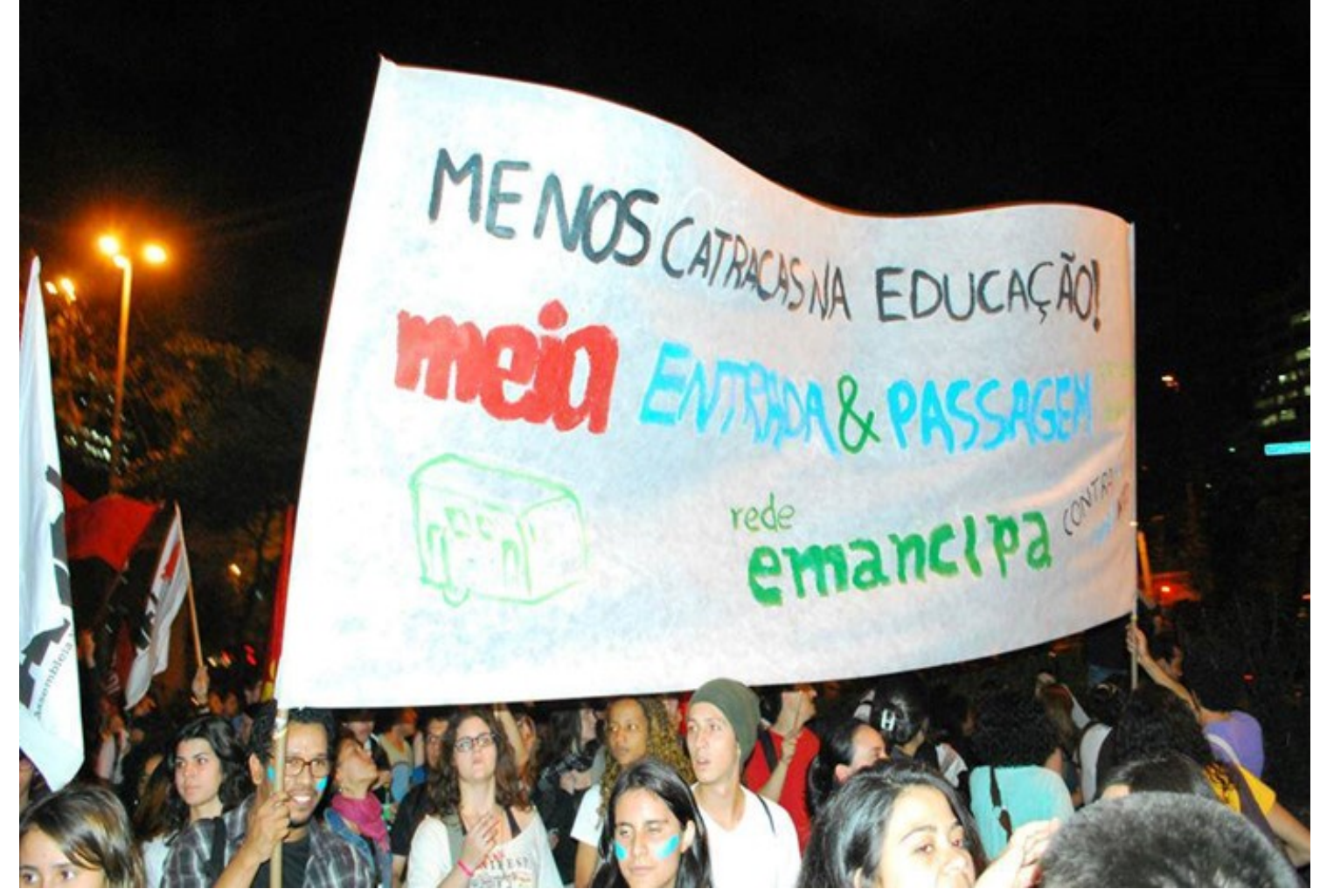



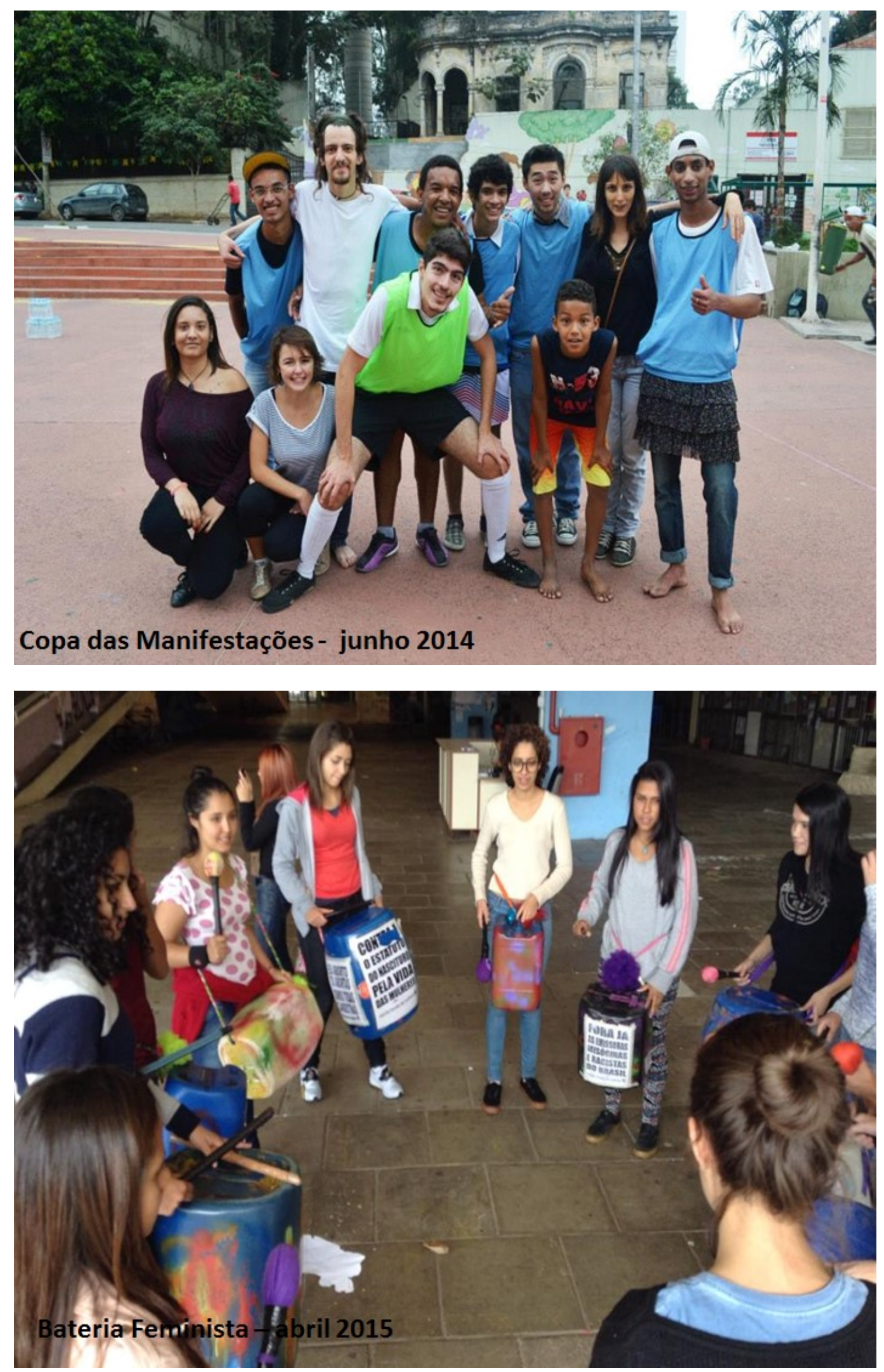


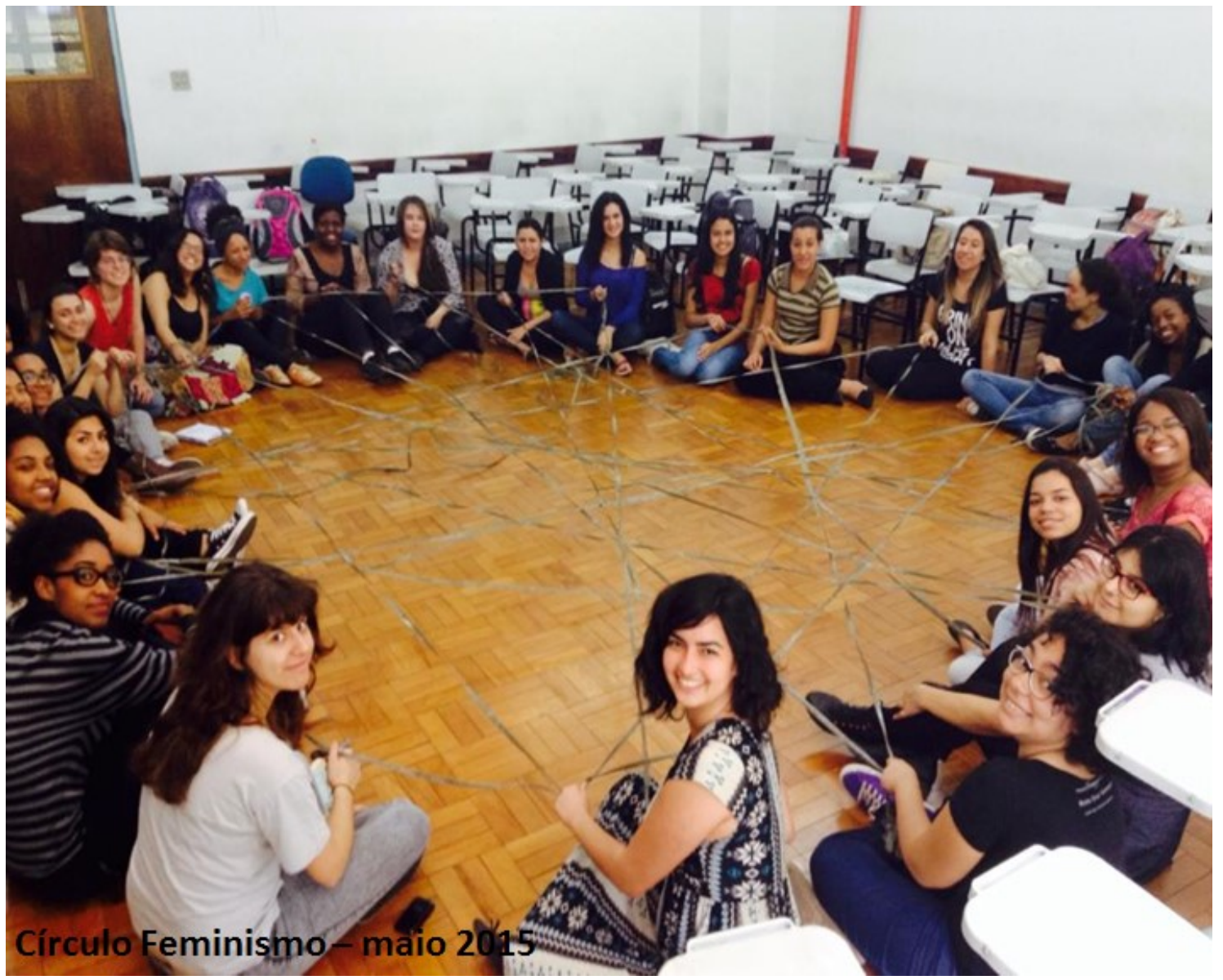

Visita Memorial da Resistência de São Paulo - julho 2015

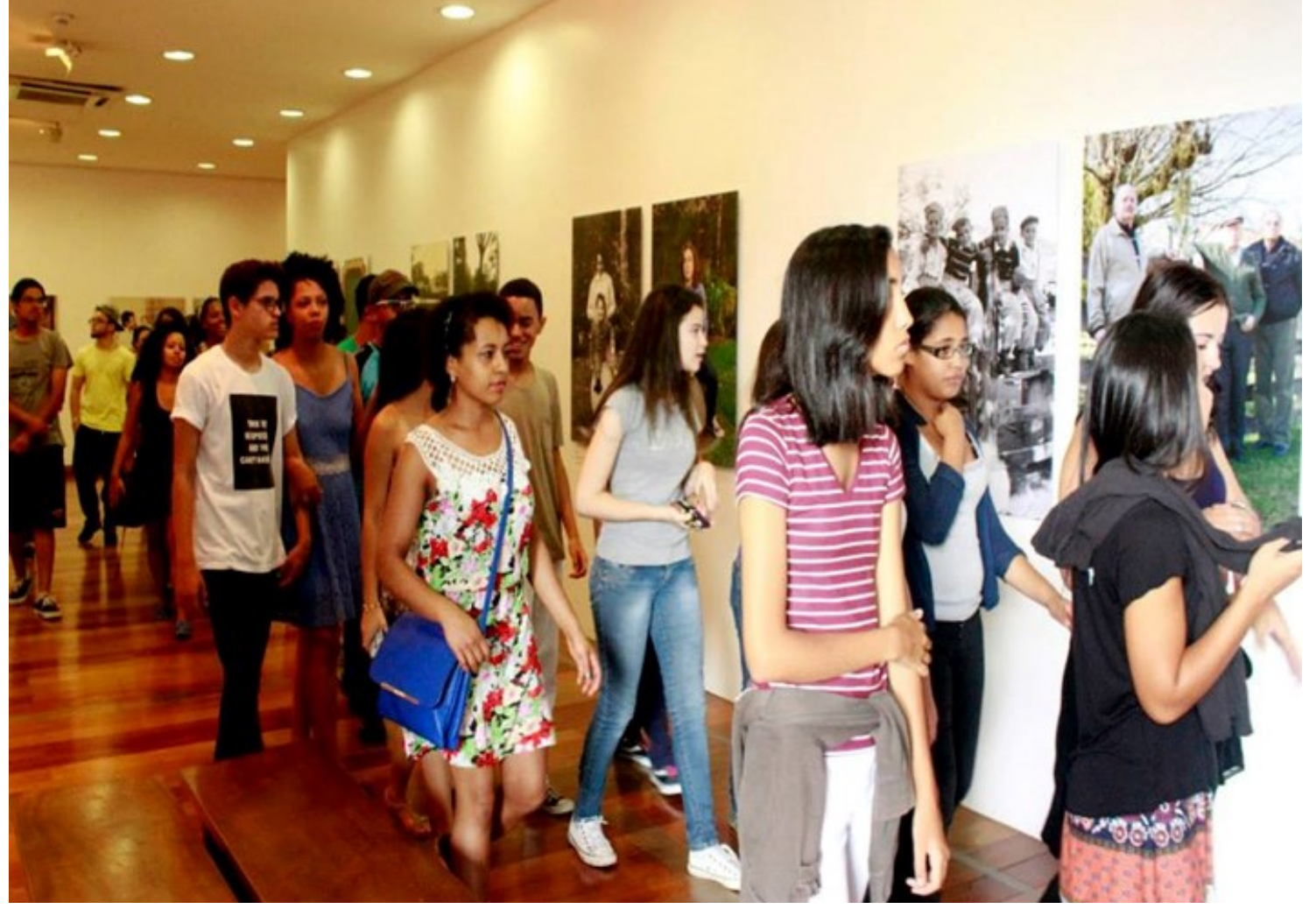



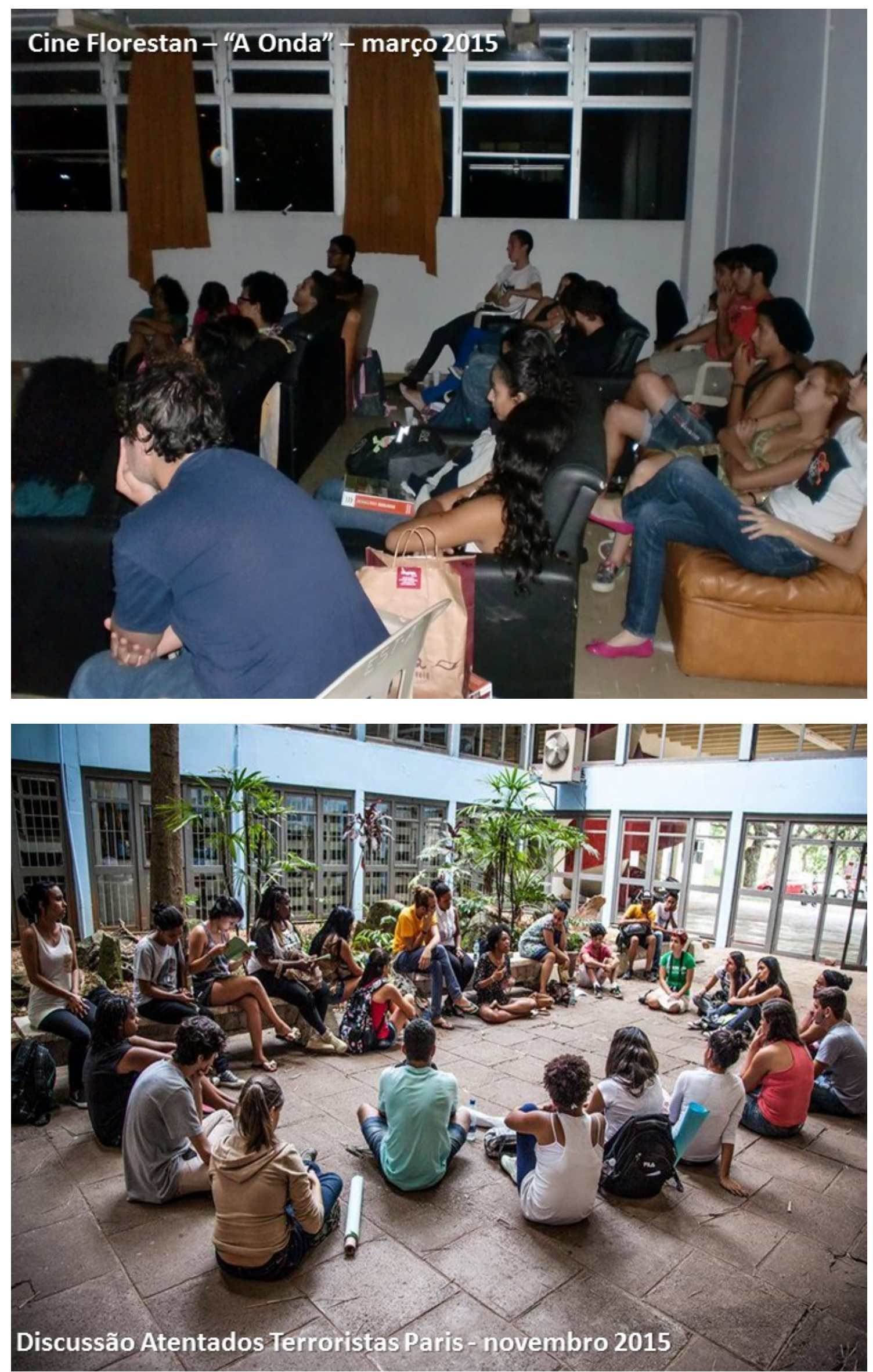